Thiago D'Angelo da Silva Oliveira

\title{
Avaliação da conformidade da pressão sonora em subestações de energia aos níveis impostos pela legislação ambiental aplicável
}

Dissertação de Mestrado

Dissertação apresentada como requisito parcial para obtenção do grau de Mestre pelo Programa de Pósgraduação em Metrologia (Área de concentração: Metrologia para Qualidade e Inovação) da PUC-Rio.

Orientador: Prof. Maurício Nogueira Frota Co-orientador: Prof. Carlos Roberto Hall Barbosa

Rio de Janeiro, agosto de 2021 


\section{Avaliação da conformidade da pressão sonora em subestações de energia aos níveis impostos pela legislação ambiental aplicável}

Dissertação apresentada como requisito parcial para obtenção do grau de Mestre pelo Programa de Pós-graduação em Metrologia (Área de concentração: Metrologia para Qualidade e Inovação) da PUC-Rio. Aprovada pela Comissão Examinadora abaixo:

Prof. Maurício Nogueira Frota

Orientador

Programa de Pós-Graduação em Metrologia - PUC-Rio

Prof. Carlos Roberto Hall Barbosa

Coorientador

Programa de Pós-Graduação em Metrologia - PUC-Rio

Prof. Daniel Ramos Louzada

Programa de Pós-Graduação em Metrologia - PUC-Rio

Prof. José Daniel Hernández Vásquez

Universidad Antonio Nariño/Colombia 
Todos os direitos reservados. A reprodução, total ou parcial, do trabalho é proibida sem autorização do autor, do orientador e da universidade.

\section{Thiago D'Angelo da Silva Oliveira}

Graduado em Engenharia Mecânica pela Universidade do Estado do Rio de Janeiro em 2013. Colaborador da equipe de pesquisadores do projeto de P\&D Light/Aneel 003820128/2019, "Controle de níveis de pressão sonora em subestação de energia". Possui experiência em análises de tensões em tubulações fazendo uso da ferramenta computacional Caesar II.

Ficha Catalográfica

Oliveira, Thiago D'Angelo da Silva

Avaliação da conformidade da pressão sonora em subestações de energia aos níveis impostos pela legislação ambiental aplicável / Thiago D'Angelo da Silva Oliveira ; orientador: Maurício Nogueira Frota ; co-orientador: Carlos Roberto Hall Barbosa. - 2021. 85 f. : il. color. ; $30 \mathrm{~cm}$

Dissertação (mestrado)-Pontifícia Universidade Católica do Rio de Janeiro, Centro Técnico Científico, Programa de Pós-Graduação em Metrologia, 2021.

Inclui bibliografia

1. Metrologia - Teses. 2. Metrologia para Qualidade e Inovação Teses. 3. Metrologia. 4. Nível de pressão sonora. 5. Ruído ambiental. 6. Subestação elétrica. 7. Limites de som. I. Frota, Maurício Nogueira. II. Barbosa, Carlos Roberto Hall. III. Pontifícia Universidade Católica do Rio de Janeiro. Centro Técnico Científico. Programa de PósGraduação em Metrologia. IV. Título. 
Dedico este trabalho aos meus pais, que me ajudaram em todos os momentos ao longo de suas vidas, compartilhando acesso ao mais precioso de seus bens: o conhecimento. 


\section{Agradecimentos}

Em primeiro lugar a Deus, por dar-me força e determinação para superar os desafios, compatibilizar outras responsabilidades profissionais que se apresentaram e concluir o Mestrado, uma aspiração de aperfeiçoamento profissional.

À minha família.

Ao meu orientador, Professor Maurício Nogueira Frota, que não me deixou desistir do meu objetivo e não desistiu de mim.

Ao Professor Carlos Hall, por todo apoio e atenção durante o curso e por acreditar que meu objetivo poderia ser realizado.

Ao amigo e colega de Mestrado Juan José Gómez Acosta, pela competente colaboração na pesquisa em campo, que agregou valor a este trabalho.

A todos que diretamente ou indiretamente contribuíram para a conclusão desta dissertação.

À CAPES e à PUC-Rio, pelos auxílios financeiros concedidos na forma de bolsas de estudo.

Ao Programa de Pós-Graduação em Metrologia da PUC-Rio, pela oportunidade de participar da Equipe de pesquisadores do P\&D Light/Aneel 00382-0128/2019, “Controle de níveis de pressão sonora em subestação de energia"), cujo projeto motivou e viabilizou o desenvolvimento de minha pesquisa de mestrado.

Aos pesquisadores Rogério Regazzi e Brunno Cunha, executivos da 3R Brasil Tecnologia Ambiental, pelas sugestões e apoio técnico durante os programas de medição da pressão sonora.

O presente trabalho foi realizado com apoio da Coordenação de Aperfeiçoamento de Pessoal de Nível Superior - Brasil (CAPES) - Código de Financiamento 001. 


\section{Resumo}

Oliveira, Thiago D’Angelo da Silva; Frota, Mauricio Nogueira; Barbosa, Carlos Roberto Hall. Avaliação da conformidade da pressão sonora em subestações de energia aos níveis impostos pela legislação ambiental aplicável. Rio de Janeiro, 2021. 85 p. Dissertação de Mestrado - Programa de Pós-Graduação em Metrologia. Área de concentração: Metrologia para Qualidade e Inovação, Pontifícia Universidade Católica do Rio de Janeiro.

Esta dissertação de mestrado tem por objetivo investigar os níveis de pressão sonora resultantes do funcionamento de subestações de energia, instaladas em áreas de considerável densidade urbana. A metodologia de desenvolvimento do trabalho fundamenta-se em dois preceitos: (i) em um programa estruturado de medições da pressão sonora e (ii) na conformidade dos valores medidos com os limites impostos pela rígida legislação ambiental aplicável. A motivação pelo tema da pesquisa resultou de uma demanda de uma concessionária de energia da cidade do Rio de Janeiro que, para se defender de uma ação civil pública impetrada pelos moradores da vizinhança de uma subestação, contratou o PósMQI para desenvolver um projeto de $\mathrm{P} \& \mathrm{D}$ capaz de avaliar alternativas de mitigação do ruído acústico na vizinhança de subestações de energia em funcionamento em zonas urbanas de alta densidade populacional. No que concerne aos resultados da pesquisa, a dissertação descreve e analisa os resultados de um programa estruturado de medições da pressão sonora na vizinhança de dez subestações inseridas em zonas urbanas. Como conclusão, foi possível mostrar que, de uma maneira geral, todas as subestações estudadas geram um nível de ruído muito próximo aos limites máximos impostos pela legislação ambiental aplicável. Desenvolvida em sintonia com um projeto de P\&D (Light/Aneel Ref. 0128/2019), que propõe alternativas tecnológicas para mitigar o nível da pressão sonora em subestações de energia, a pesquisa de mestrado desenvolveu extensa revisão da literatura especializada sobre o tema e uma análise crítica do acervo normativo, diretivas e leis aplicáveis ao controle de ruído acústico em zonas urbanas.

\section{Palavras-chave}

Metrologia; Nível de pressão sonora; ruído ambiental; subestação elétrica; limites de som; conformidade à legislação ambiental. 


\section{Abstract}

Oliveira, Thiago D'Angelo da Silva; Frota, Mauricio Nogueira (Advisor); Barbosa, Carlos Roberto Hall (Co-Advisor). Assessment of compliance to environmental legislation of sound pressure levels in power substations. Rio de Janeiro, 2021. 85 p. Dissertação de Mestrado - Programa de PósGraduação em Metrologia. Área de concentração: Metrologia para Qualidade e Inovação, Pontifícia Universidade Católica do Rio de Janeiro.

This master's research aims to investigate the sound pressure levels resulting from the operation of power substations, installed in areas of considerable urban density. The methodology for developing the work is based on two precepts: (i) a structured program of sound pressure measurements and (ii) the compliance of the measured values with the limits imposed by the strict applicable environmental legislation. The motivation for the research theme resulted from a demand from an electricity utility in the city of Rio de Janeiro that, to defend itself from a public civil action filed by residents of a nearby substation, hired PósMQI to develop a capable R\&D project to evaluate alternatives for mitigating acoustic noise in the vicinity of power substations operating in urban areas with high population density. Regarding the research results, the dissertation describes and analyzes the outcomes of a structured program of sound pressure measurements in the vicinity of ten substations located in urban areas. In conclusion, it was possible to show that, in general, all studied substations generate a noise level very close to the maximum limits imposed by the applicable environmental legislation. Developed in line with an R\&D project (Light/Aneel Ref. 0128/2019), which proposes technological alternatives to mitigate the level of sound pressure in power substations, the master's research developed an extensive review of the specialized literature on the subject and a critical analysis of the normative asset of, directives and laws applicable to the control of acoustic noise in urban areas.

\section{Keywords}

Metrology; Pressure sound level; environmental noise; electrical substation; sound limits; compliance to the environmental legislation. 


\section{Sumário}

1 Introdução 16

1.1 Contextualização 18

$\begin{array}{ll}1.2 \text { Motivação } & 18\end{array}$

$\begin{array}{ll}1.3 \text { Objetivos: geral e específicos } & 19\end{array}$

$\begin{array}{ll}1.4 \text { Metodologia } & 19\end{array}$

$\begin{array}{ll}1.5 \text { Estrutura da dissertação } & 20\end{array}$

2 Fundamentos de acústica $\quad 21$

$\begin{array}{ll}\text { 2.1 Propriedades da onda sonora, conceitos e definições } & 21\end{array}$

$\begin{array}{ll}\text { 2.1.1 O conceito associado à denominação som } & 21\end{array}$

2.1.2 Velocidade de propagação acústica 23

2.1.3 Características físicas de uma onda acústica 23

2.1.4 Intensidade, potência e pressão sonora 25

2.1.5 Caracterização do sinal acústico (banda de oitava) 27

2.1.6 Caracterização das fontes sonoras $\quad 29$

2.2 Descritores para caracterização do sinal acústico 29

2.2.1 Nível de pressão sonora ponderada, $L_{p A} \quad 30$

2.2.2 Nível de ruído contínuo equivalente, $L_{\text {eq }} \quad 31$

2.2.3 Nível de ruído contínuo equivalente ponderado A, $L_{\text {Aeq }} 32$

2.2.4 Descritores estatísticos 32

2.2.5 Comparação do nível corrigido $L_{R} \quad 33$

2.3 Instrumentação para medição de parâmetros acústicos 34

2.3.1 Medição de pressão sonora 34

2.3.2 Confiabilidade metrológica das medições realizadas 36

$\begin{array}{ll}\text { 2.3.3 Visualização do campo acústico } & 36\end{array}$

3 Legislação ambiental aplicável ao controle acústico 41

3.1 Normas relacionadas ao tema da pesquisa 41 
3.1.1 Normas internacionais relacionadas ao tema da pesquisa 41

3.1.2 Normas brasileiras relacionadas ao tema da pesquisa 43

3.2 Leis relacionadas ao tema da pesquisa 45

3.2.1 Legislação federal relacionada ao tema da pesquisa 45

3.2.2 Legislação estadual relacionada ao tema da pesquisa 46

3.2.3 Legislação municipal relacionada ao tema da pesquisa 46

4 Critérios de seleção e caracterização das subestações estudadas 53

4.1 Subestações de energia elétrica selecionadas $\quad 54$

4.2 Detalhamento das subestações $\quad 55$

4.2.1 Caracteristicas das subestações $\quad 55$

4.2.2 Pontos de medição e suas características $\quad 56$

$\begin{array}{ll}4.3 \text { Resultados das medições } & 60\end{array}$

$\begin{array}{ll}4.4 \text { Discussão dos resultados } & 65\end{array}$

$\begin{array}{ll}5 \text { Conclusões e trabalhos futuros } & 67\end{array}$

6 Referências bibliográficas $\quad 69$

$\begin{array}{ll}7 \text { Apêndice A } & 73\end{array}$

8 Anexo A: Confiabilidade metrológica das medições de pressão sonora 78 


\section{Lista de figuras}

Figura 1: Desenho da pesquisa, seus componestes e métodos

Figura 2: Características da onda acústica: comprimento de onda e amplitude 24

Figura 3: Caracterização da diferença de fase

Figura 4: Curvas de ponderação ACZ

Figura 5: Dosímetro CESVA DC112

Figura 6: Sonômetro classe 1 (CESVA modelo SC-420) 36

Figura 7: Câmera 3D (48 microfones) direcionada para o alvo de medição 38

Figura 8: Exemplo de imagem de visualização do campo acústico 39

Figura 9: Subestações elétricas selecionadas 55

Figura 10: Posicionamento da subestação Leme 58

Figura 11: Caracterização dos pontos de medição (subestações em Niterói) 58

Figura 12: Imagens aéreas das subestações estudadas do Rio de Janeiro 59

Figura 13: Níveis de pressão de ruído medidos ao longo do tempo. 60

Figura 14: Espectro de frequência não mostrando características tonais 61

Figura 15: Características tonais 61

Figura 16: Níveis de pressão de ruído na subestação São Lourenço 73

Figura 17: Níveis de pressão de ruído na subestação Ingá 74

Figura 18: Níveis de pressão de ruído na subestação Jardim Botânico 74

Figura 19: Níveis de pressão de ruído na subestação Humaitá 75

Figura 20: Níveis de pressão de ruído na subestação Major Vaz 75

Figura 21: Níveis de pressão de ruído na subestação Leme 76

Figura 22: Níveis de pressão de ruído na subestação Uruguai 77 


\section{Lista de tabelas}

Tabela 1: Bandas de frequência preferidas (oitava e 1/3 de oitava) ...................28

Tabela 2: Caracterização de som tonal ......................................................... 29

Tabela 3: Características funcionais da câmera 3D (48 microphones) ................ 39

Tabela 4: Nível de critério de avaliação para ambientes externos, em $\mathrm{dB}(\mathrm{A})$.....49 49

Tabela 5: Níveis máximos para emissão de sons e ruídos ................................ 51

Tabela 6: Caracterização das subestações estudadas ........................................54

Tabela 7: Caracterização das subestações estudadas ........................................56

Tabela 8: Caracterização dos pontos de medição ...........................................57

Tabela 9: Resultados das medições para as dez subestações. ......................... 62 


\section{Lista de siglas e abreviaturas}

PAIR Perda auditiva induzida por ruído

P\&D Pesquisa e Desenvolvimento

$S I$

Sistema Internacional de Unidades

RMS Root Mean Square

PWL Power Watt Level (Nível da potência sonora)

SWL Sound Watt Level (Nivel da potência sonora)

SPL Sound Pressure Level (Nivel da potência sonora)

ISO International Organization for Standardization

ABNT Associação Brasileira de Normas Técnicas

FFT Transformada rápida de Fourier

INMETRO Instituto Nacional de Metrologia, Qualidade e Tecnologia

$R B C$

Rede Brasileira de Calibração

MNPS Medidor de nível de pressão sonora

IEC

International Electrotechnical Commission

$T C$

Comitê Técnico

PNRS

Política Nacional de Resíduos Sólidos

SGA Sistema de Gestão Ambiental

CONAMA Conselho Nacional do Meio Ambiente

IBAMA Instituto Brasileiro do Meio Ambiente e dos Recursos Naturais Renováveis

SMAC Secretaria Municipal de Meio Ambiente

NCA Nivel de Critério de Avaliação

PUR Plano Urbanístico da Região

ZE Zoneamento

SE Subestação elétrica de alta tensão

PMed (Ponto de Medição): Local de realização da medição 
ENEL Empresa de distribuição de energia elétrica com atuação na área estudada

LD Linha de distribuição

$d B \quad$ Unidade SI da pressão sonora (valor linear).

$d B(A) \quad$ Unidade não SI, usualmente empregada para se expressar $o$ resultado da medição da pressão sonora com ponderação na Curva A (expressa a sensação captada pelo ouvido humano).

$\mathrm{Hz} \quad$ Unidade de medida de frequência.

MVA Unidade de medida que corresponde a $10^{6}$ volt-ampere.

$\mathrm{Pa} \quad$ Pascal.

us Unidade de medida de tempo, equivalente a milionésimo de segundo.

ms Unidade de medida de tempo que corresponde a $10^{-3}$ segundo.

Velocidade de propagação do som

$\lambda$

Comprimento de onda

Frequência

$T$

Período

$\alpha$

Amplitude

$\theta$

Fase

$J$

Joule

$s$

Segundo

W

Watts

$m^{2}$

Área

$10^{-12} \mathrm{~W}$

Potência sonora de referência de 1 picowatt

$\log$

Logaritmo Decimal

$N$

Newton

$\mu P a$

Micropascal

$k H z$

Unidade de medida de frequência (símbolo: $\mathrm{kHz}$ ) equivalente a mil hertz $(103 \mathrm{~Hz})$

Laeq

Nível de ruído contínuo equivalente ponderado na escala $A$

$L_{\text {Aeq, } T}$

Nível sonoro contínuo equivalente, ponderado A 
Lafmax $\quad$ Valor máximo medido durante um determinado período de tempo

Lpa Nivel de pressão sonora ponderada

Leq Nível de ruído contínuo equivalente

Te Média ao longo do tempo

$L_{A}(t) \quad$ Nível de pressão sonora ponderado A instantâneo

L10 Nível de pressão sonora excedido em 10\% do tempo de medida efetiva

L90 Nível de pressão sonora excedido em $90 \%$ do tempo de medida efetiva

$L_{R} \quad$ Nível de pressão sonora corrigido ponderado em A conforme NBR 10151:2019

L95 Nivel de pressão sonora estatístico do ruído de fundo com ponderação $A$

Lx Nível de pressão sonora excedido em $x \%$ do tempo total de exposição

RLAeq Limites de níveis de pressão sonora

$K_{I} \quad 5 \mathrm{~dB}$ quando for caracterizado som impulsivo

$K_{T}$

$5 d B$ quando for caracterizado som tonal

$D$

Distância 
Jesus adiante paz e guia Encomendo-me a Deus e a virgem Maria

Os doze apóstolos meus irmãos Eu andarei vestido, armado, cercado Com as armas de São Jorge São Jorge sentou praça na cavalaria Eu estou feliz porque eu também sou da sua companhia Eu estou vestido com as roupas e as armas de Jorge Para que meus inimigos tendo pés, não me alcancem Tendo mãos e não me peguem, tendo olhos não me vejam E nem em pensamento eles possam ter para me fazerem mal

Armas de fogo o meu corpo não alcançaram Facas e lanças se quebrem se em meu corpo tocar Cordas e correntes se arrebentem se meu corpo amarrar Pois eu estou vestido com as roupas e as armas de Jorge

Salve Jorge

Oração de São Jorge 


\section{1 Introdução}

A década de 90 do século XVII marcou o início de um período de concentração e modernização dos serviços públicos no Brasil, em especial aqueles relacionados à introdução da energia elétrica no processo de urbanização das principais cidades brasileiras [1]. $\mathrm{O}$ acesso à energia elétrica alavancou inúmeras inovações ao longo dos anos (e.g.: uso de bondes elétricos; iluminação pública; crescimento da atividade comercial e industrial; uso doméstico), não apenas proporcionando conforto, como transformando de forma radical a vida das pessoas. Ao criar novas oportunidades, o uso da energia elétrica impôs um novo padrão de desenvolvimento, requerendo maiores investimentos por parte do poder público e das empresas prestadoras de serviços públicos, padrão este intensamente percebido e que estimulou um intenso processo de unificação [1].

A instalação de subestações de energia elétrica próximas à demanda por eletricidade no meio urbano representa um exemplo concreto desses desenvolvimentos. Entretanto, ao beneficiar a população local e reduzir expressivos custos de transmissão da energia, impactou o ambiente, quer no aspecto visual, quer no que concerne à poluição acústica, causando depreciação dos imóveis que ocupam a vizinhança das subestações e, ainda mais grave, desconforto e degradação da qualidade de vida, expondo a população a riscos a diferentes morbidades. A exposição a ruído ${ }^{1}$ continuo, da ordem de 85 decibels $(\mathrm{dB})$ por oito horas por dia, comprovadamente, podem ocasionar a Perda Auditiva Induzida por Ruído (PAIR) [2].

A despeito do efeito nocivo causado pelo ruído, eliminá-lo nem sempre é possível. No caso particular do ruído gerado pelo funcionamento de transformadores de alta tensão, que são os principais equipamentos de uma subestação de energia elétrica, este resulta do fenômeno da magnetostricção, devido a alteração das dimensões de materiais ferromagnéticos (chapas magnéticas de grãos orientados) quando excitados por campos magnéticos. Mais especificamente, o ruído acústico é gerado pela expansão e contração periódicas das placas de aço que formam o núcleo laminado do transformador, devido ao campo magnético que é induzido pela passagem de corrente elétrica alternada pelas suas bobinas. Este fenômeno de expansão e contração ocorre com uma frequência duas vezes maior que a frequência da corrente alternada. Para as condições de operação da rede elétrica brasileira, o ruído acústico é gerado na frequência característica de $120 \mathrm{~Hz}$, além de alguns harmônicos superiores (tipicamente, $240 \mathrm{~Hz}$ e $360 \mathrm{~Hz}$ ), frequências

\footnotetext{
${ }^{1} \mathrm{O}$ termo ruído é usado para descrever sons indesejáveis ou desagradáveis. A exposição excessiva ao ruído pode causar lesões graves e deve ser evitada sempre que possível [4].
} 
essas na faixa audível pelo ouvido humano, com variações dessas frequências em torno dos valores nominais, tipicamente $\pm 0,2 \mathrm{~Hz}$. Este é um fenômeno que também ocorre com circuitos magnéticos de máquinas elétricas em geral e, em particular, com transformadores de tensão. Em alguns casos, o ruído acústico gerado pelo funcionamento dos transformadores pode atingir valores entre 75 a $85 \mathrm{~dB}$ (medido a $1 \mathrm{~m}$ da caixa do transformador) [3], o que excede, consideravelmente, os valores impostos pela legislação ambiental aplicável $(55 \mathrm{~dB}$, no período diurno e $50 \mathrm{~dB}$, no período noturno). Sabidamente, os altos níveis de pressão sonora geram desconforto aos moradores que habitam o entorno de subestações, o que pode ser comprovado por ações públicas ${ }^{2}$ impetradas na justiça.

Esta pesquisa de mestrado foi motivada pelo projeto de P\&D (Light/Aneel 00382-0128/2019, “Controle de níveis de pressão sonora em subestação de energia") em desenvolvimento sob a coordenação do Programa de Pós-Graduação em Metrologia da PUC-Rio. Fomentado pela concessionária de energia Light SESA, o projeto de $\mathrm{P} \& \mathrm{D}$ estuda alternativas tecnológicas capazes de atenuar o nível da pressão sonora em uma de suas subestações de energia, com o propósito de adequá-la aos limites impostos pela legislação ambiental e apresentar elementos de defesa contra a ação civil exorada por moradores da vizinhança da subestação de energia Light/Leme, na cidade do Rio de Janeiro.

Já que é impossível eliminar por completo o ruído acústico gerado primariamente pelo fenômeno da magnetostricção, o projeto de $\mathrm{P} \& \mathrm{D}$ em desenvolvimento estuda meios de atenuá-lo aos níveis legais impostos pela legislação, assim contribuindo para o bem estar da comunidade vizinha da subestação. Enquanto o projeto de P\&D concentra-se na adequação do nível da pressão sonora na subestação alvo da ação pública, esta pesquisa de mestrado, com o apoio da concessionária, estuda outras subestações de energia (operadas pela Light SESA e por outras concessionárias), para avaliar se a situação identificada na subestação Leme se refere a um problema localizado ou se denota um problema mais amplo, igualmente observado em outras subestações de energia elétrica em operação no Estado do Rio de Janeiro. Considerando que cada subestação possui características próprias (e.g.: número de transformadores em operação, carga, tensão e potência; espaçamento entre os transformadores; barreiras naturais que desviam e refletem a onda acústica), esta pesquisa de mestrado também contribui para aumentar o conhecimento sobre este sutil problema que não pode ser eliminado já que inerente ao próprio funcionamento dos transformadores, mas que precisa se adequar aos limites impostos pela rígida legislação ambiental.

\footnotetext{
${ }^{2}$ Objeto da LEI 7.347, de 24 de julho de 1985, a ação civil pública trata, dentre outros temas, de danos causados ao meio-ambiente, ao consumidor. A ação civil pública é um instrumento processual, previsto na Constituição Federal brasileira e em normas infraconstitucionais, de que podem se valer o Ministério Público.
} 


\section{1}

\section{Contextualização}

Em 2016, no contexto dos Jogos Olímpicos do Rio de Janeiro, a Light reforçou a capacidade da subestação Leme, instalando dois transformadores de 40 MVA cada, para atender aos eventos esportivos da praia de Copacabana. Não obstante o aparente benefício de se aumentar a potência elétrica disponível à comunidade local, o substancial aumento do porte do transformador gerou desconforto (ruído acústico), mobilizando moradores da vizinhança da subestação a formalizarem uma ação civil contra a concessionária de energia.

No setor industrial, a principal premissa a seguir é assegurar que as técnicas utilizadas para controle de ruído não interfiram no funcionamento dos equipamentos instalados, o que certamente limita os procedimentos de controle a serem utilizados. A literatura especializada define que as técnicas e procedimentos a serem implementados devem abordar o problema de mitigação de ruído segundo quatro estratégias distintas: (i) na fonte de ruído; (ii) no caminho de propagação; (iii) no receptor; e (iv) em uma combinação das anteriores [5].

No âmbito do projeto de P\&D Light/Aneel (Ref.: 00382-0128/2019) em desenvolvimento, medições preliminares da pressão sonora confirmaram que, de fato, o nível da pressão sonora em pontos críticos da vizinhança e do interior da subestação excedem os limites da legislação ambiental [4]. Para equacionar o problema, duas soluções complementares foram estudadas e avaliadas pelo projeto de P\&D: (i) implementação de um sistema de mascaramento acústico pela sobreposição de um ruído sintetizado (inspirado em sons da natureza) para eliminar o componente tonal do ruído (parte que agrava o desconforto ao ouvido humano); e (ii) concepção e instalação de barreiras acústicas capazes de atenuar o nível da pressão sonora para assegurar a sua conformidade aos níveis impostos pela legislação ambiental. $\mathrm{O}$ estudo destas alternativas de solução não faz parte do escopo desta dissertação de mestrado, mas estão sendo avaliadas em profundidade pelo projeto de $\mathrm{P} \& \mathrm{D}$ ao qual esta dissertação de mestrado está diretamente associada.

\section{2 \\ Motivação}

Ao contribuir com o desenvolvimento do projeto de $\mathrm{P} \& \mathrm{D}$ acima caracterizado, cujo objetivo central visa adequar o nível da pressão sonora da subestação Light/Leme de energia aos limites da legislação vigente, esta pesquisa de mestrado não objetiva implementar nenhuma ação corretiva, mas, sim, estudar e mapear o nível da pressão sonora nesta e em outras subestações de energia em operação no Estado do Rio de Janeiro. A motivação para desenvolvimento desta pesquisa de mestrado surgiu da necessidade não apenas de orientar estudos e alternativas de intervenções capazes de equacionar o grave problema relacionado ao ruído acústico gerado pelo funcionamento de transformadores de energia elétrica 
mas, também, de contribuir para o aprimoramento das normas e regulamentações em acústica, já que não constitui tarefa trivial discernir os limites aceitáveis de ruído, quando este é intrínseco ao funcionamento dos próprios transformadores de energia.

\section{3}

\section{Objetivos: geral e específicos}

Fundamentado em um programa estruturado de medição, a pesquisa de mestrado teve como objetivo central realizar um diagnóstico do nível da pressão sonora em subestações de energia em operação no Rio de Janeiro, à luz das recomendações (voluntárias) de normas e da legislação ambiental, que impõe, por força de Lei, limites compulsórios que precisam ser atendidos.

Para alcançar este objetivo geral, os seguintes objetivos específicos foram formulados:

- Identificar as recomendações de normas técnicas associadas à medição e caracterização de ruído acústico e as restrições impostas pela legislação ambiental aplicável.

- Caracterizar o nível do ruído acústico gerado pela operação da subestação de energia Light Leme, e por outras subestações em operação em áreas metropolitanas de alta densidade populacional.

- Avaliar a conformidade do nível da pressão sonora em subestações de energia à legislação ambiental aplicável.

\section{4 \\ Metodologia}

A Figura 1 apresenta o desenho da pesquisa, destacando seus componentes e métodos, de acordo com três fases principais: (i) exploratória e descritiva; (ii) pesquisa aplicada; e (iii) conclusiva. 

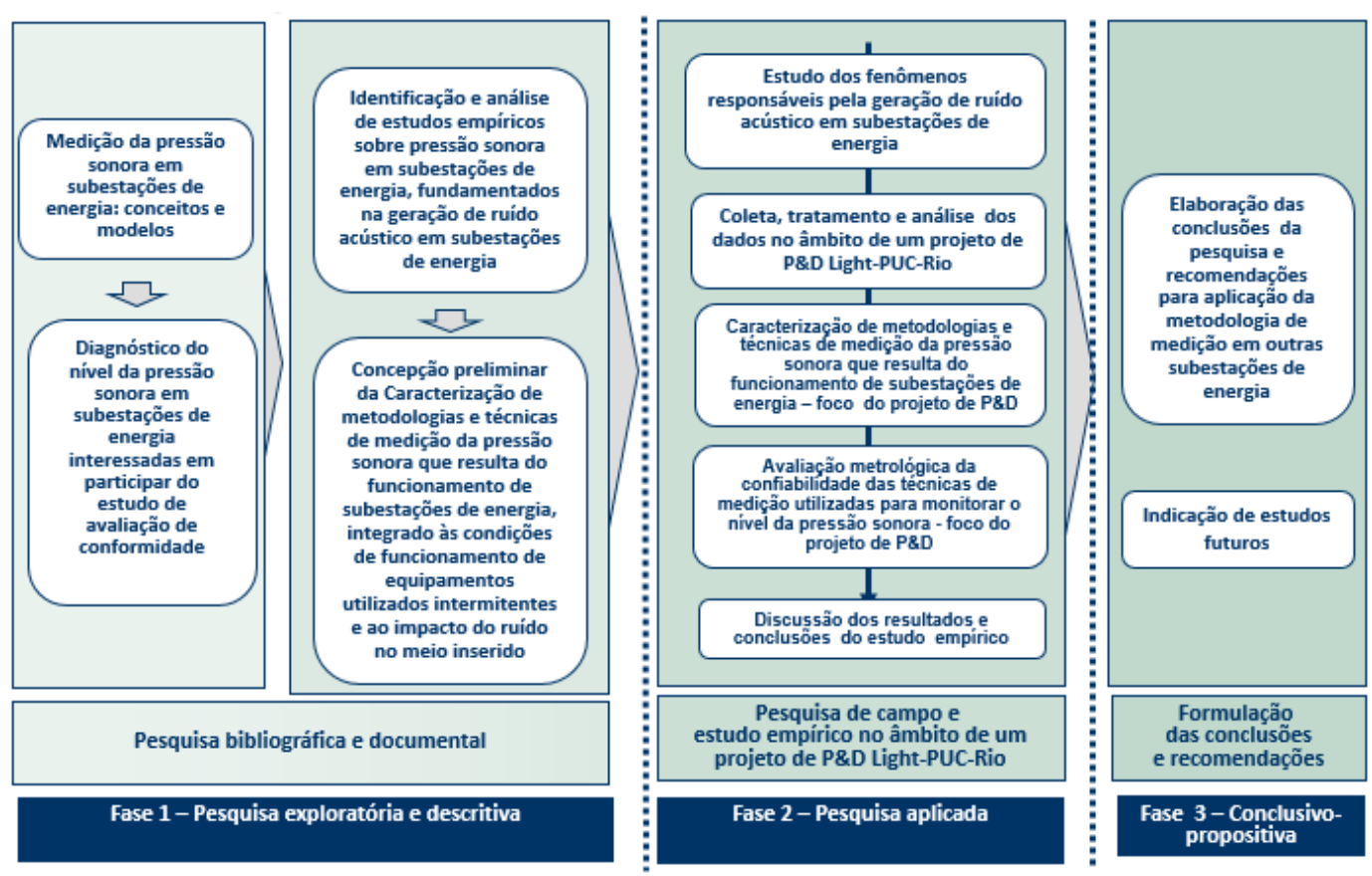

Figura 1: Desenho da pesquisa, seus componentes e métodos

\section{5 \\ Estrutura da dissertação}

A dissertação encontra-se estruturada em cinco capítulos, incluindo esta introdução.

O capítulo 2 fundamenta os conceitos de acústica requeridos para desenvolvimento do trabalho e discute as principais metodologias e técnicas de medição de propriedades do campo acústico gerado pelo funcionamento de subestações de energia elétrica.

O capítulo 3 apresenta o recenseamento das normas técnicas e legislação ambiental aplicável ao problema objeto do estudo e discute as alternativas de avaliação da conformidade de níveis da pressão sonora em subestações de energia elétrica.

O capítulo 4 apresenta as subestações de energia selecionadas para fundamentar a pesquisa com base em um plano estruturado de medição da pressão sonora nos ambientes interno e externo de cada uma das subestações, todas em funcionamento no Estado do Rio de Janeiro (nas cidades do Rio de Janeiro e em Niterói). Com base nos resultados das medições da pressão acústica em cada subestação, o trabalho avalia a conformidade aos limites impostos pela legislação e normas aplicáveis.

Concluindo o trabalho, o capítulo 5 apresenta as conclusões da pesquisa e encaminha sugestões para desdobramentos futuros do trabalho. 


\section{2 \\ Fundamentos de acústica}

As ondas sonoras são ondas mecânicas que se originam de vibrações do meio (no caso o ar) e possuem frequência entre $20 \mathrm{~Hz}$ e $20000 \mathrm{~Hz}$. São detectadas pelo ouvido humano, por meio da membrana timpânica situada no fundo do canal auditivo externo, que transmite as vibrações do ar (frequência e amplitude) ao ouvido médio, para processamento pelo cérebro. Um exemplo clássico é a explosão de uma bomba que, ao explodir em um determinado ponto, comprime as moléculas de ar que ocupam o local da detonação e atinge o ouvido, convertendo a onda acústica em estímulo nervoso.

\section{1}

\section{Propriedades da onda sonora, conceitos e definições}

Dentre os diferentes tipos de ondas sonoras, foram estudadas as ondas mecânicas que se originam de vibrações do meio (no caso o ar), na faixa de frequência entre $20 \mathrm{~Hz}$ e $20000 \mathrm{~Hz}$, passíveis de serem detectadas pelo ouvido humano. A captação da onda sonora se dá por meio da membrana timpânica situada no fundo do canal auditivo externo, que transmite as vibrações do ar (frequência e amplitude) ao ouvido médio, convertidas em sinais nervosos e processadas pelo cérebro. Um exemplo clássico é a explosão de uma bomba que, ao explodir em um determinado ponto, comprime as moléculas de ar que ocupam o local da detonação e atinge o ouvido, convertendo a onda acústica em estímulo nervoso.

\subsection{1}

\section{O conceito associado à denominação som}

Duas são as abordagens clássicas de se estudar o som. A acústica física estuda a parte material do fenômeno sonoro, enquanto a psicoacústica trata da percepção do fenômeno sonoro pelos sentidos [8]. A física ondulatória estuda os fenômenos que se apresentam em formas de ondas. No que concerne o presente estudo, dois são os tipos básicos de onda acústica: (i) as ondas mecânicas, que atuam no nível das moléculas, cujo fenômeno perceptivo associado é o som e (ii) ondas eletromagnéticas, causadas pelo movimento de partículas subatômicas, cujos fenômenos perceptivos associados são, principalmente, a luz e as cores [8]. Todos esses modos estão interligados, mas cada uma enfoca um aspecto específico do fenômeno físico [8]. 
Ondas mecânicas podem ser de dois tipos: longitudinais (as moléculas movem-se na mesma direção de propagação da onda) e transversais (as moléculas movem-se perpendicularmente à direção de propagação). As ondas de pressão que caracterizam o som - denominadas de ondas sonoras - são do tipo longitudinal, propagando-se por uma série de compressões/descompressões em um meio, físico, no caso em pauta o ar. As ondas transversais são usualmente encontradas nas vibrações de partes de certos instrumentos musicais, a exemplo das membranas e cordas de instrumentos de percussão (comumente construídas de peles) [8].

O som é uma qualidade perceptiva que é resultado de distúrbios das moléculas de um meio em um certo espaço de tempo. Esses distúrbios, por sua vez, apresentam-se em forma de ondas em sua propagação pelo meio. Para este fenômeno ocorrer há a necessidade de três elementos relacionados em um sistema:

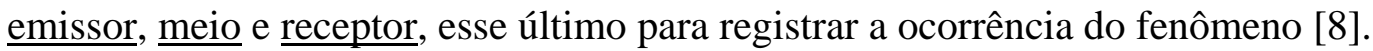

O emissor tem a função de produzir um distúrbio no meio, que será percebido pelo receptor. É importante notar que o meio tem influência na qualidade do distúrbio, pois afeta a maneira como este se propaga. Estes distúrbios, de natureza mecânica, resultam de pequenas e rápidas variações de pressão do meio, causadas pelo movimento, compressões e rarefações (descompressões, expansões) das moléculas do meio. Esse movimento é sempre relacionado com uma onda de pressão que se propaga pelo meio [8].

Os sons naturais são, na sua maioria, combinações de sinais. Um som puro, monotônico, representado por uma onda senoidal pura, possui uma velocidade de oscilação ou frequência (medida em Hz) e uma amplitude ou energia (medida em decibels) bem caracterizadas. Seres humanos e vários animais percebem sons com o sentido da audição, com seus ouvidos, o que permite identificar a distância e a posição da fonte sonora, percepção essa denominada de audição estereofônica. Muitos sons de baixa frequência são, também, percebidos por outras partes do corpo. Estudos específicos revelam que elefantes se comunicam por meio de infrassons [10].

O som percebido pelo sistema auditivo é provocado pela variação da pressão atmosférica ambiente. A menor variação que o sistema auditivo humano é capaz de detectar é da ordem de 2 x 10-5 Pa, denominado limiar de audibilidade [9]. O limiar da dor causada pelo ruído acústico, por outro lado, corresponde à variação da pressão em torno de $20 \mathrm{~Pa}$. No entanto, esta variação deve ocorrer em forma de ciclos para que seja percebida [9].

O sistema auditivo humano é capaz de determinar variações de pressão que duram entre $50 \square \mathrm{s}$ e $50 \mathrm{~ms}$. Desta forma, se o período das oscilações estiver neste intervalo e a variação de pressão estiver acima do limiar de audibilidade, perceberse-á o som. Sendo assim, a frequência mínima audível é de $20 \mathrm{~Hz}$, enquanto a frequência máxima chega a $20000 \mathrm{~Hz}$. Sons de frequência acima de $20 \mathrm{kHz}$ são denominados de ultrassons, e sons de frequência abaixo de $20 \mathrm{~Hz}$ são denominados de infrassons [10]. 


\subsection{2}

\section{Velocidade de propagação acústica}

As ondas mecânicas longitudinais viajam a uma velocidade constante, dependendo do meio em que se propagam [8]. Os fatores que contribuem para a variação de velocidade do som em sólidos incluem a densidade do material (i.e., a relação entre volume e massa deste material) e o módulo de Young, relacionado à elasticidade do material em questão [8]. A velocidade de propagação da ona acústica é proporcional ao quadrado do quociente entre o módulo de Young e a densidade do meio sólido (meio de propagação do sinal acústico). Maior densidade implica em menor velocidade, enquanto maior elasticidade implica em maior velocidade [8]. No caso dos gases, a velocidade de propagação do som $(v)$ no meio depende do tipo de gás, de seu peso molecular e de sua temperatura absoluta, sendo descrita por [8]

$$
v=\sqrt{\frac{\gamma R T}{M}}
$$

nesta expressão:

M: peso molecular do gás (2,87 x 10-2 kg mol-1, no caso do ar)

$\gamma$ : constante adimensional que depende do gás (1,4 para o ar)

R: constante dos gases (8,31 J K-1 mol-1)

T: temperatura absoluta (em kelvin)

No caso das ondas transversais, o cálculo da velocidade de propagação é mais complexo, pois para qualquer meio maior que uma corda ideal (fina e infinita), ele é influenciado pela geometria do meio de propagação e pelo tipo da onda que se propaga.

\subsection{3}

\section{Características físicas de uma onda acústica}

Em Física, uma onda é uma perturbação oscilante de alguma grandeza física no espaço, sendo periódica no tempo.

O comprimento de onda é o espaço percorrido pela perturbação, até o ponto em que a partícula passa a repetir o movimento. Também pode ser definido como a distância correspondente a uma oscilação completa. Usualmente, o comprimento de onda é descrito pela letra grega $\lambda$.

A frequência, definida pelo inverso do período ( $\mathrm{f}=1 / \mathrm{T}$ ) é medida em ciclos por segundo, que define a unidade do Sistema Internacional de Unidades (SI) denominada hertz $(\mathrm{Hz})$. A frequência $\mathrm{f}$ (ou o período $\mathrm{T}$ ) e o comprimento de onda $\lambda$ relacionam-se por meio da velocidade de propagação $v$, pelo produto $v=\mathrm{f} \lambda$. 
A amplitude $(\alpha)$ da onda acústica, ilustrada na Figura 2, representa o máximo afastamento, durante a oscilação, em relação à posição de equilíbrio.

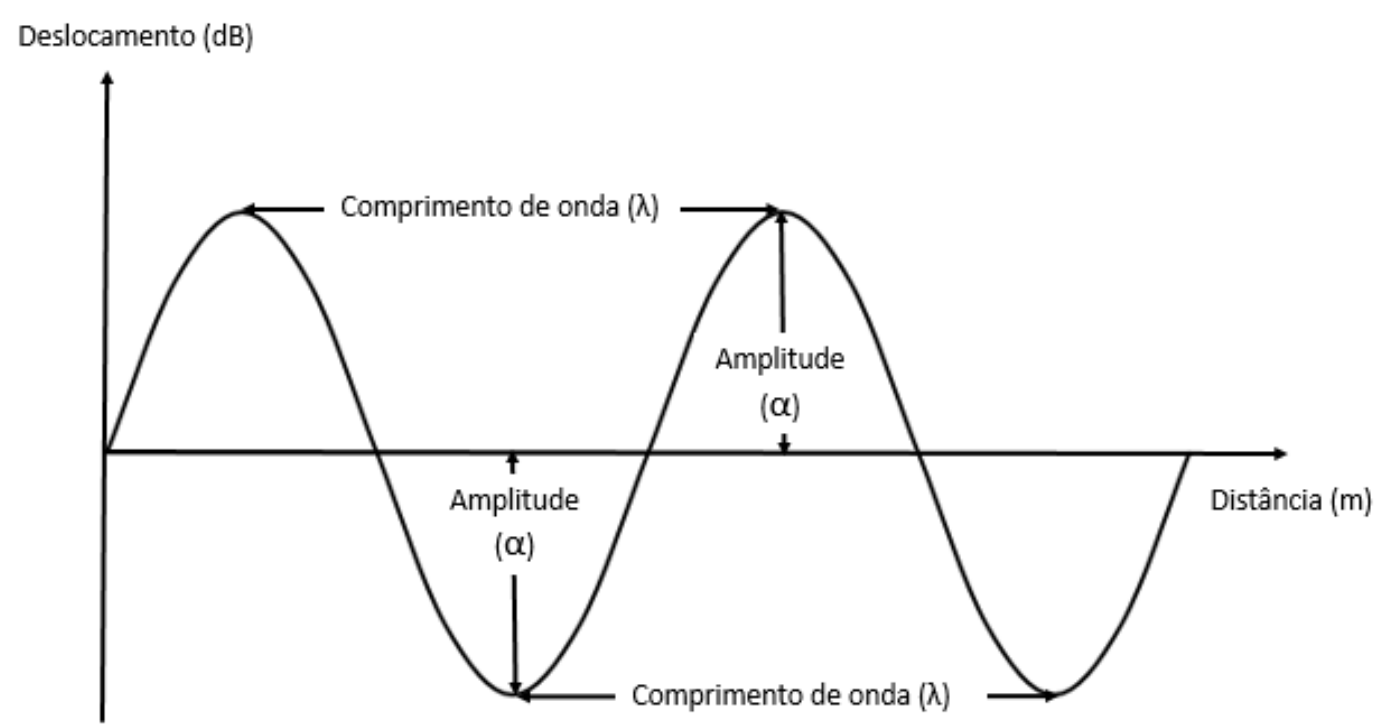

Figura 2: Características da onda acústica: comprimento de onda e amplitude

Nesta figura 2, o valor $\alpha$ denota a amplitude da onda, também conhecida como "amplitude de pico" para diferenciar de outro conceito de amplitude, usado especialmente em engenharia elétrica: root mean square amplitude (ou amplitude RMS), definida como a raiz quadrada da média temporal da distância vertical entre o gráfico e o eixo horizontal ao quadrado [64].

Uma onda senoidal pode ser entendida como um movimento que se propaga ao longo de um eixo, o qual pode representar uma distância ou tempo. A relação desse movimento com um ponto de referência é chamada de fase [65]. Diz-se que diferenças de fase entre duas ondas geram interferências construtivas (quando a onda resultante tem amplitude maior que a das ondas individuais) ou interferências destrutivas (quando a amplitude da onda resultante é menor que a das ondas individuais). Isso quer dizer que, quando ondas sonoras interagem no ambiente, elas estão se reforçando (interferência construtiva) ou cancelando (interferência destrutiva) [65]. Os sons que são ouvidos no ambiente têm um comportamento complexo e raramente haverá um cancelamento total de uma determinada frequência devido às diferenças de fase [65]. A Figura 3 ilustra o que se denomina diferença de fase. Nessa figura 3, o eixo horizontal representa um ângulo (fase) que está aumentando com o tempo. 


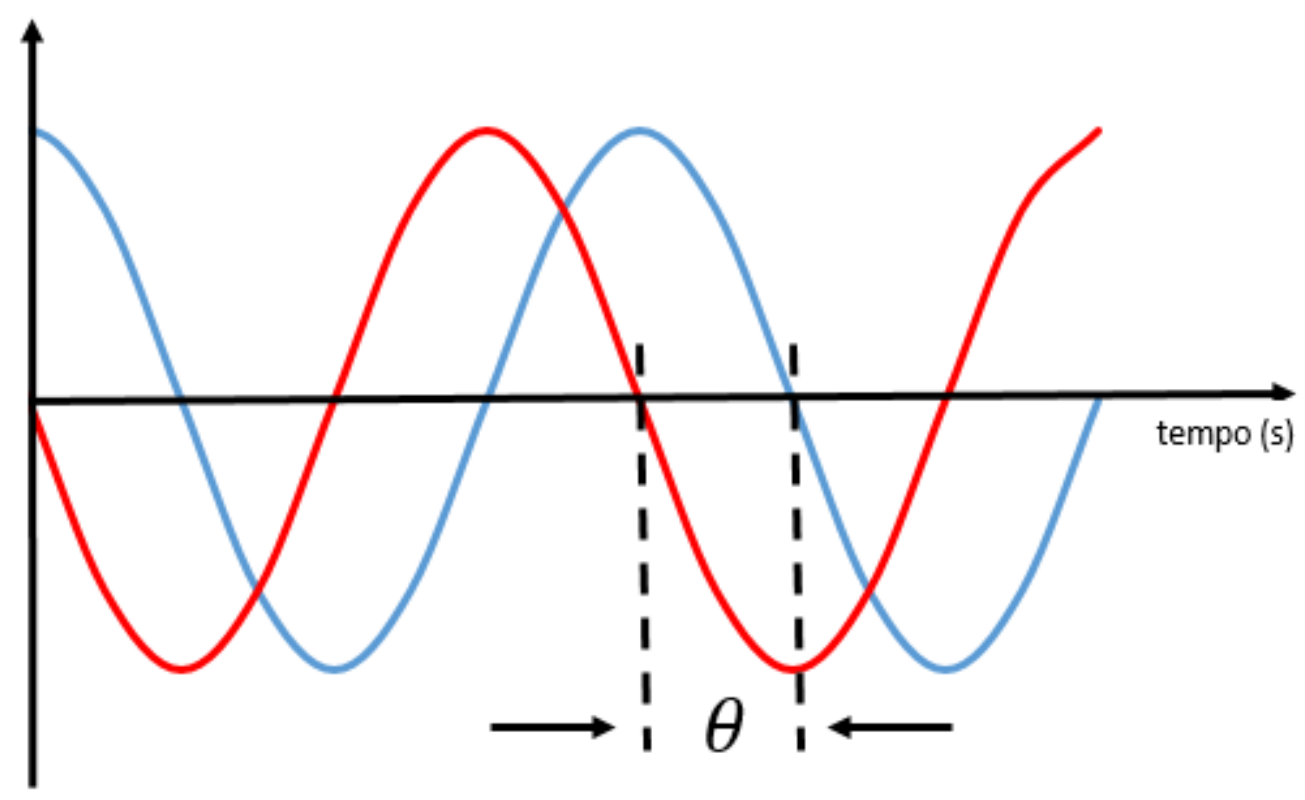

Figura 3: Caracterização da diferença de fase

\subsection{4 \\ Intensidade, potência e pressão sonora}

A energia de uma onda sonora é a medida da quantidade de som nela presente. Dependendo do foco do estudo, deseja-se conhecer a quantidade de energia transmitida por unidade de tempo, e não a energia total transferida. A quantidade de energia expressa por unidade de tempo (joules por segundo) denota a potência da onda sonora, expressa em watts (W). O som é uma quantidade tridimensional, sendo medido pela grandeza denominada intensidade sonora, que expressa a densidade da potência de um som propagando em uma direção particular e é medida no SI em watts por unidade de área (W/m2).

Coloquialmente, a intensidade sonora é a qualidade que permite caracterizar se um som é forte ou fraco, em função da energia que a onda sonora transfere.

O nível de potência sonora (PWL, Power Watt Level ou SWL, Sound Watt Level), por sua vez, é a potência sonora total irradiada em todas as direções pela fonte sonora. O nível de pressão sonora (usualmente denominado pela sigla em inglês SPL, Sound Pressure Level) é o que se consegue medir, fisicamente, utilizando-se um medidor de nível de som, valor comumente ponderado para um único número $(\mathrm{dB})$. O nível de pressão sonora (SPL) depende da distância, da posição da fonte e do ambiente, de reflexos do solo, portanto, do tempo de reverberação e do volume do espaço considerado. Essa é a razão pela qual o valor da medição do SPL varia com a distância da fonte, tendo em vista a perda de energia para a atmosfera. Ou seja, o simples fato de se afastar de uma fonte de som reduzse a percepção do SPL, particularmente perceptível ao ar livre. Já o nível de potência sonora (SWL) não depende da distância, posição ou ambiente. Essa é a diferença crucial entre esses dois conceitos. É um valor teórico, não diretamente 
mensurável. Uma fonte de ruído terá a mesma potência sonora, independentemente de onde for colocada. O correto entendimento desses conceitos é fundamental para se conseguir comparar diretamente duas fontes de som.

A pressão sonora é expressa, em decibels, pelo logaritmo de uma razão entre a potência sonora real e a potência sonora de referência de 1 picowatt $(10-12 \mathrm{~W})$, conforme definido por

$$
S W L=10 \log \left(\frac{W_{r}}{W_{\text {ref }}}\right)
$$

nesta expressão:

SWL: nível de potência sonora;

Wr: potência sonora real (em W); e

Wref: potência sonora de referência (10-12 W)

O nível de potência sonora é uma medida da potência sonora total gerada por uma fonte arbitrária, independe do seu contexto acústico.

O nível de pressão sonora (SPL, do Inglês "sound pressure level") é a grandeza mais usual quando se fala em amplitude da onda sonora, por duas razões: pela sensibilidade do ouvido às variações de pressão e por ser uma grandeza simples de ser medida. A pressão sonora para fontes sonoras reais pode variar entre $20 \mathrm{x}$ 10-6 Pa e $20 \mathrm{~Pa}(1 \mathrm{~Pa}=1 \mathrm{Nm}-2)$. Esses dois níveis de pressão correspondem, aproximadamente, ao mínimo de som percebido pelo ouvido humano $(20 \mu \mathrm{Pa})$ e ao limiar da dor (20 Pa), a $1 \mathrm{kHz}$ de frequência. Se for comparado o valor para o mínimo da audição humana com a pressão atmosférica média de $105 \mathrm{~Pa}$, observase como é alta a sensibilidade do ouvido humano. Por causa de características da audição humana, o nível de pressão sonora também é usualmente expresso em uma escala logarítmica. Ela é baseada no logaritmo da razão entre a pressão sonora real e o limiar da audição a $1 \mathrm{kHz}$.

O nível de pressão sonora, equivalente contínuo ponderado na escala $\mathrm{A}$, geralmente representado por $\mathrm{L}_{\text {Aeq, }}$ representa o nível de um som contínuo (estacionário) que, em um intervalo de tempo específico, tem a mesma energia sonora do som em estudo, cujo nível varia com o tempo (ISO, 1982). Além de ser utilizado como padrão de análise para o ruído ambiental, o LAeq também é utilizado na avaliação da exposição ao ruído ocupacional. Ele representa o potencial de lesão auditiva do nível variável (oscilante), que depende não somente do seu nível como também da sua duração [20]. O LAeq representa, assim, o nível do ruído contínuo (fixo) ao qual as pessoas estão sujeitas em várias situações, devido aos diversos tipos de ruído, sendo equivalente ao ruído original, que é variável. 


\subsection{5 \\ Caracterização do sinal acústico (banda de oitava)}

Uma banda de oitava é definida como uma faixa de frequências em que a proporção dos limites de frequência superior e inferior é igual a 2. Conjuntos de filtros de banda de oitava são frequentemente incluídos como um recurso para se medir o nível de som.

Se os filtros fossem "perfeitos", toda a energia fora da faixa de frequência da oitava seria atenuada ou cancelada, mas em um filtro "real" a atenuação não é perfeita fora da faixa da oitava. Normalmente, a atenuação do filtro da banda de oitava é da ordem de $-25 \mathrm{~dB}$ em uma frequência uma oitava abaixo ou uma oitava acima da frequência central da banda de oitava.

Para uma análise mais detalhada da distribuição de frequência da energia acústica, filtros de banda de $1 / 3$ de oitava podem ser usados. As frequências dos sons são de difícil identificação, sem uma classificação básica universal. Por exemplo: qual a frequência da voz de um cantor? A resposta seria muito variável, poderia dizer que é $250 \mathrm{~Hz}$ ou $255 \mathrm{~Hz}$, ou ainda $301 \mathrm{~Hz}$. Assim, foi feita uma divisão das frequências entre $63 \mathrm{~Hz}$ a $8 \mathrm{kHz}$, feita em oito níveis, por isso o nome de Banda de Oitava, são elas, $63 \mathrm{~Hz}, 125 \mathrm{~Hz}, 250 \mathrm{~Hz}, 500 \mathrm{~Hz}, 1$ kHz, 2 kHz, 4 kHz e 8 kHz, ficando mais fácil de identificar as frequências em grupos, tendo valores mais resumidos.

Os filtros de banda de oitava (1/1) e de banda de 1/3 oitava são frequentemente utilizados para observar a banda de frequência em que ocorre o nível máximo de pressão sonora, podendo ser identificadas as características do sistema que se relacionam com a geração de ruído.

De acordo com Bies [59], as bandas de frequência preferidas para análise de banda de oitava e 1/3 de oitava estão resumidas na Tabela 1. 
Tabela 1: Bandas de frequência preferidas (oitava e 1/3 de oitava)

\begin{tabular}{|c|c|c|c|c|}
\hline \multirow{2}{*}{$\begin{array}{c}\text { Número da } \\
\text { banda }\end{array}$} & \multirow{2}{*}{$\begin{array}{l}\text { Frequência central } \\
\text { da banda de oitava }\end{array}$} & \multirow{2}{*}{$\begin{array}{l}\text { 1/3 Frequência central } \\
\text { da banda de oitava }\end{array}$} & \multicolumn{2}{|c|}{ Limites de banda } \\
\hline & & & Inferior & Superior \\
\hline-1 & & 0,8 & 0,7 & 0,9 \\
\hline 0 & 1 & 1 & 0,9 & 1,1 \\
\hline 1 & & 1,25 & 1,1 & 1,4 \\
\hline 2 & & 1,6 & 1,4 & 1,8 \\
\hline 3 & 2 & 2 & 1,8 & 2,2 \\
\hline 4 & & 2,5 & 2,2 & 2,8 \\
\hline 5 & & 3,15 & 2,8 & 3,5 \\
\hline 6 & 4 & 4 & 3,5 & 4,4 \\
\hline 7 & & 5 & 4,4 & 5,6 \\
\hline 8 & & 6,3 & 5,6 & 7 \\
\hline 9 & 8 & 8 & 7 & 9 \\
\hline 10 & & 10 & 9 & 11 \\
\hline 11 & & 12,5 & 11 & 14 \\
\hline 12 & 16 & 16 & 14 & 18 \\
\hline 13 & & 20 & 18 & 22 \\
\hline 14 & & 25 & 22 & 28 \\
\hline 15 & 31,5 & 31,5 & 28 & 35 \\
\hline 16 & & 40 & 35 & 44 \\
\hline 17 & & 50 & 44 & 57 \\
\hline 18 & 63 & 63 & 57 & 71 \\
\hline 19 & & 80 & 71 & 88 \\
\hline 20 & & 100 & 88 & 113 \\
\hline 21 & 125 & 125 & 113 & 141 \\
\hline 22 & & 160 & 141 & 176 \\
\hline 23 & & 200 & 176 & 225 \\
\hline 24 & 250 & 250 & 225 & 283 \\
\hline 25 & & 315 & 283 & 353 \\
\hline 26 & & 400 & 353 & 440 \\
\hline 27 & 500 & 500 & 440 & 565 \\
\hline 28 & & 630 & 565 & 707 \\
\hline 29 & & 800 & 707 & 880 \\
\hline 30 & 1000 & 1000 & 880 & 1130 \\
\hline 31 & & 1250 & 1130 & 1414 \\
\hline 32 & & 1600 & 1414 & 1760 \\
\hline 33 & 2000 & 2000 & 1760 & 2250 \\
\hline 34 & & 2500 & 2250 & 2825 \\
\hline 35 & & 3150 & 2825 & 3530 \\
\hline 36 & 4000 & 4000 & 3530 & 4400 \\
\hline 37 & & 5000 & 4400 & 5650 \\
\hline 38 & & 6300 & 5650 & 7070 \\
\hline 39 & 8000 & 8000 & 7070 & 8800 \\
\hline 40 & & 10000 & 8800 & 11300 \\
\hline 41 & & 12500 & 11300 & 14140 \\
\hline 42 & 16000 & 16000 & 14140 & 17600 \\
\hline 43 & & 20000 & 17600 & 22500 \\
\hline
\end{tabular}

Fonte: Engineering noise control: theory and practice [59] 


\subsection{6}

\section{Caracterização das fontes sonoras}

Para som contínuo ou intermitente, a avaliação é realizada por meio da determinação do LAeq,T do som proveniente da(s) fonte(s) sonora(s) objeto de avaliação, chamado de nível de pressão sonora específico [7].

A caracterização de som impulsivo (pressão sonora detectada em um curto espaço de tempo, usualmente inferior a 1 segundo) decorre da(s) fonte(s) sonora(s) objeto de medição. Esta se dá quando o resultado da subtração aritmética entre LAFmax e o LAeq,T, medido durante a ocorrência do som impulsivo, for igual ou superior a $6 \mathrm{~dB}$ (LAFmax - LAeq,T $\geq 6 \mathrm{~dB}$ ). Deve constar no relatório da medição sonora, não apenas a medição da pressão sonora, mas também, a medição do tempo de integração $\mathrm{T}$ e a justificativa de sua escolha. Recomenda-se que o tempo de integração $\mathrm{T}$ adotado na medição de LAeq,T contemple pelo menos dois ou mais eventos de sons impulsivos [7].

A caracterização de som tonal (som contido em uma faixa de frequência de um terço de oitava, que se destaca das frequências das bandas adjacentes do espectro e que, em geral, causa desconforto ao ouvido humano) se dá com base em critérios estabelecidos em normas técnicas. A característica tonal do ruído ocorre quando o nível de pressão sonora contínuo equivalente na banda de $1 / 3$ de oitava de interesse excede os níveis de pressão sonora contínuos em ambas as bandas de 1/3 de oitava adjacentes, conforme critério definido na Tabela 2 [7], extraída da norma ABNT 10151:2019.

Tabela 2: Caracterização de som tonal

\begin{tabular}{cc}
\hline $\begin{array}{c}\text { Banda de } 1 / 3 \text { de oitava de } \\
\text { interesse }\end{array}$ & $\begin{array}{c}\text { Diferença aritmética entre o } \mathrm{LZeq}, \mathrm{T}, \mathrm{f} \mathrm{Hz}(1 / 3) \text { da banda de } \\
\text { interesse e o LZeq, }, \mathrm{fHz}(1 / 3) \text { de cada banda adjacente }\end{array}$ \\
\hline $25 \mathrm{~Hz}$ a $125 \mathrm{~Hz}$ & $\geq 15 \mathrm{~dB}$ \\
$160 \mathrm{~Hz}$ a $400 \mathrm{~Hz}$ & $\geq 8 \mathrm{~dB}$ \\
$500 \mathrm{~Hz}$ a $10000 \mathrm{~Hz}$ & $\geq 5 \mathrm{~dB}$ \\
\hline
\end{tabular}

Fonte: Norma ABNT NBR 10151:2019

Em alguns casos, este método pode não ser suficiente para identificar o som tonal quando este situar-se entre duas bandas adjacentes ou quando houver som tonal em mais de uma banda adjacente. Até que sejam publicadas normas técnicas específicas, recomenda-se análise por transformada rápida de Fourier FFT [7].

\section{2 \\ Descritores para caracterização do sinal acústico}

Diversos são os descritores utilizados na literatura especializada para se avaliar o ruído ambiental: $\mathrm{Lp}_{\mathrm{A}}, \mathrm{L}_{\mathrm{eq}}$, $\mathrm{L}_{\mathrm{Aeq}}, \mathrm{LR}_{\mathrm{R}}$, detalhados nas seções subsequentes. 


\subsection{1 \\ Nível de pressão sonora ponderada, LpA}

Devido ao fato de o ouvido humano possuir sensibilidade distinta em diferentes frequências, os valores brutos por ele captados não estão diretamente relacionados com o volume do som em questão. Para tornar as medições mais representativas da intensidade associada a qualquer som, é desejável ponderar os valores de cada frequência de acordo com a maneira como o ouvido humano responde ao som. Para atender a diferentes propósitos, o resultado da medição de pressão sonora (ou nível de ruído) é expresso com base em uma curva de ponderação A, considerando que há, normalmente, uma correlação aceitável entre os resultados medidos e as avaliações subjetivas. Nesse sentido, a curva A, mostrada na Figura 4, cumpre o propósito de produzir uma representação de valor único de um espectro sonoro completo baseado nas ponderações $\mathrm{A}, \mathrm{C}, \mathrm{e} \mathrm{Z}$.

As curvas de ruído são uma forma comum de medir e especificar o ruído de fundo em ambientes. Seu objetivo é produzir uma representação de valor único de um espectro sonoro completo. Organizações de padrões internacionais reconhecem a necessidade de objetivar julgamentos sobre a quantidade de ruído ambiente em espaços fechados, oferecendo definições para várias curvas de ruído. A ponderação pela Curva A representa com propriedade a resposta auditiva do ouvido humano3.

\footnotetext{
${ }^{3}$ ISO 1996-1:2016. Acoustics - Description, measurement and assessment of environmental noise - Part 1: Basic quantities and assessment procedures.
} 


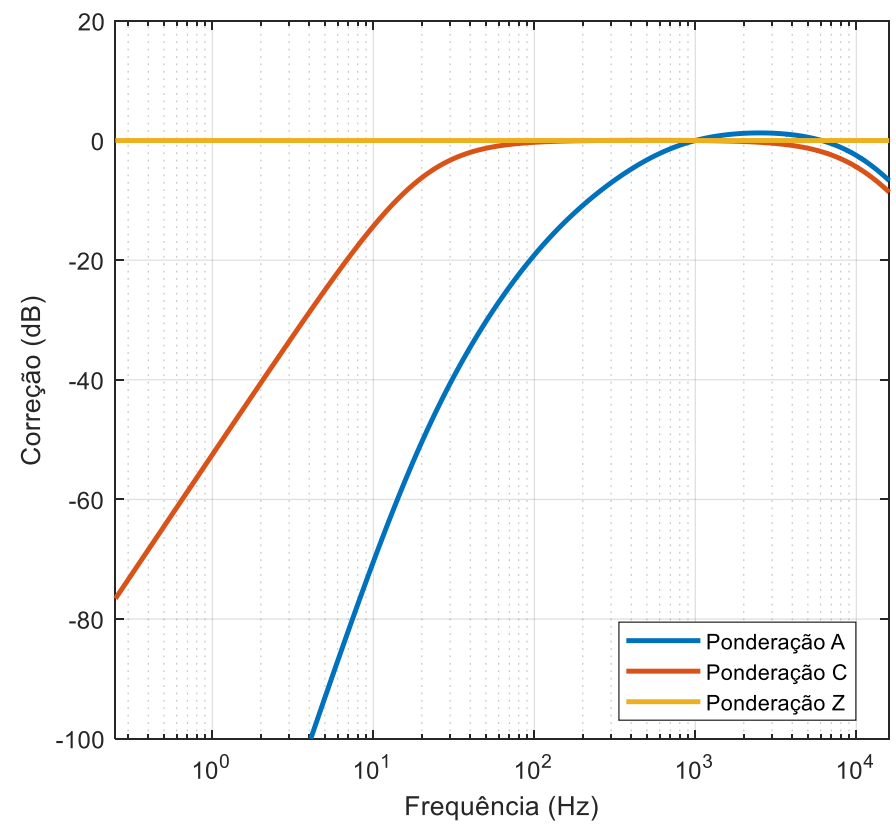

Figura 4: Curvas de ponderação ACZ

Assim, LpA denota o nível da pressão sonora (SPL) utilizando-se o filtro de ponderação A no instrumento de medição, sendo definido pela expressão

$$
L_{A}=10 \log _{10}\left(\frac{P_{A}}{P_{0}}\right)^{2} \quad d B
$$

Sendo:

$P A$ : pressão efetiva avaliada com ponderação A

P0: pressão de referência $(20 \mu P a)$

\subsection{2}

\section{Nível de ruído contínuo equivalente, Leq}

Este nível de ruído, denotado pela abreviação Leq, denota um nível médio de energia, sendo o nível que é exibido na maioria dos medidores de nível de som digital. O tempo de cálculo da média pode ser definido pelo usuário e o nível de ruído pode ser atualizado continuamente, substituindo-se a primeira amostra na média pela amostra mais recente [59].

Assim, o Nível de Ruído Contínuo Equivalente, Leq, calculado ao longo do tempo, $T e$, em termos do nível de pressão sonora instantâneo, $L(t)$, é dado por

$$
L_{e q, T e}=10 \log _{10}\left[\frac{1}{T_{e}} \int_{0}^{T_{e}} 10^{\frac{L(t)}{10}} d t\right]
$$

sendo: 
Te o período durante o qual a medição é feita

\subsection{3 \\ Nível de ruído contínuo equivalente ponderado $A$, $L_{\text {Aeq }}$}

O nível de ruído contínuo equivalente ponderado A, LAeq, tem uma definição semelhante ao nível de ruído contínuo não ponderado, definido na seção 2.2.2, exceto pelo fato de que o sinal de ruído é ponderado antes de ser elevado ao quadrado e calculado pela média [59]. Após a ponderação A, é calculada a média do quadrado da pressão, geralmente referida como média de energia. $\mathrm{O}$ nível de ruído contínuo equivalente ponderado A é usado como um descritor de ruído ocupacional e ambiental e, para uma média ao longo do tempo, Te, pode ser escrito em termos do nível de pressão sonora ponderado A instantâneo, $L A(t)$, pela expressão

$$
L_{A e q, T e}=10 \log _{10}\left[\frac{1}{T_{e}} \int_{0}^{T_{e}} 10^{\left.\frac{L A(t)}{10} d t\right]}\right.
$$

Além de ser utilizado como padrão de análise para o ruído ambiental, o LAeq também é utilizado na avaliação da exposição ao ruído ocupacional. Ele representa o potencial de lesão auditiva do nível variável (oscilante), que depende não somente do seu nível como também da sua duração [20]. O LAeq representa, assim, o nível do ruído contínuo (fixo) ao qual as pessoas estão sujeitas, em várias situações, devido aos diversos tipos de ruído, sendo equivalente ao ruído original que é variável. O LAeq é o descritor sonoro mais importante. Medições de banda larga, por exemplo, são realizadas utilizando-se a ponderação em frequência segundo a curva A, quando se avalia o ruído ambiental. Ele é o indexador de ruído mais utilizado no estudo do ruído de tráfego rodoviário, sendo que o nível corrigido (rating level) e os níveis estatísticos, tais como L10 e L90, também são utilizados [21].

\subsection{4 \\ Descritores estatísticos}

Descritores estatísticos são frequentemente utilizados para caracterizar sons variáveis no tempo, a exemplo do ruído de tráfego e do ruído de fundo, em ambientes urbanos e rurais [59]. Os descritores mais comumente usados são L10 (para ruído de tráfego) e L95 (para ruído de fundo) [59]. A quantidade L10 denota o nível de ruído que é excedido em $10 \%$ do tempo [59]. De forma mais geral, Lx é o nível de ruído que é excedido $\mathrm{x} \%$ do tempo total de exposição em relação ao nível de pressão sonora, comumente expressa em $\mathrm{dB}(\mathrm{A})$, para indicar que é o valor ponderado pela Curva $\mathrm{A}$, muito embora $\mathrm{dB}(\mathrm{A})$ não seja uma unidade do Sistema Internacional de Unidade (SI). 


\section{2 .5}

\section{Comparação do nível corrigido $L_{R}$}

O entendimento do LR (nível de pressão sonora corrigido ponderado em A conforme a norma brasileira NBR 10151:2019) é feito utilizando-se a avaliação pelo método detalhado, que é aplicado para avaliação sonora decorrente de fontes de sons contínuos, intermitentes, impulsivos ou tonais.

A avaliação é realizada pela comparação do nível corrigido LR, calculado a partir do LAeq,T(total) medido com a contribuição dos sons provenientes das fontes objeto de avaliação, no respectivo período/horário, com os limites de RLAeq, denominado limites de níveis de pressão sonora $(\mathrm{dB})$ no período diurno e noturno, em função do uso e ocupação do solo no local da medição. Considera-se aceitável o resultado do LR quando este for menor ou igual ao estabelecido na Tabela 2 [7].

Quando o LR calculado a partir do LAeq,T(total) for superior ao limite de RLAeq, para a área e o horário em questão, estabelecido na Tabela 2, a avaliação deve ser realizada pela comparação do nível corrigido LR calculado a partir do nível de pressão sonora específico LAeq(específico) das fontes sonoras objeto da avaliação, conforme no item 9.2.3 da norma brasileira NBR 10151:2019 [7]. Considera-se aceitável o resultado do LR quando este for menor ou igual ao estabelecido na Tabela 2.

O LR é calculado por

$$
L_{R}=L_{A e q}+K_{I}+K_{T}
$$

sendo:

KI é igual a $5 \mathrm{~dB}$ quando for caracterizado som impulsivo, conforme descrito no item 9.3 da norma brasileira NBR 10151:2019 [7].

KT é igual a $5 \mathrm{~dB}$ quando for caracterizado som tonal, conforme descrito no item 9.4 da norma brasileira NBR 10151:2019 [7].

LAeq o nível de pressão sonora contínuo equivalente ponderada em A associado às fontes sonoras objeto da avaliação, conforme descrito no item 9.2 da norma brasileira NBR 10151:2019 [7], aplicável a sons de natureza contínua ou intermitente. 


\section{3 \\ Instrumentação para medição de parâmetros acústicos}

\subsection{1 \\ Medição de pressão sonora}

A maioria dos instrumentos comerciais de medição do nível de som são unidades digitais controladas por microprocessador. Vários níveis de análise acústica podem ser fornecidos como recursos do medidor de nível de som. Além disso, muitos medidores de nível de som têm a capacidade de exibir suas leituras em tempo real, em plataformas web.

O decibelímetro (também denominado de sonômetro) é um instrumento utilizado para realizar a medição da pressão sonora e, consequentemente, da intensidade do som, já que a pressão sonora é uma grandeza representativa da sensação auditiva de volume sonoro, quando a medição é devidamente ponderada.

Esse equipamento requer calibração para indicar o correto valor da pressão sonora em decibels. Atualmente, no mercado brasileiro, existem equipamentos digitais capazes de realizar medições da pressão sonora entre $30 \mathrm{~dB}$ e $130 \mathrm{~dB}$.

Medidores básicos de nível de som medem e exibem o nível de ruído em tempo real. As versões mais simples disponíveis no mercado brasileiro não calculam a média e, tampouco, armazenam resultados.

Instrumentos mais elaborados para medição da pressão sonora, além de medir e exibir o nível do som, calculam a média ou integram os níveis de som ao longo do tempo. Esta é uma função importante porque o risco de perda de audição e os limites de exposição a ruídos são baseados nos níveis de som médios que foram medidos. Esses medidores também podem ter filtros especiais para medir o ruído de impulso/impacto ou filtros de banda de oitava para dividir o espectro de som em segmentos menores.

Dosímetros de ruído pessoal são dispositivos portáteis comumente utilizados por trabalhadores por longos períodos de tempo, durante sua jornada de trabalho. A Figura 5 ilustra uma versão de um dosímetro comercialmente disponível no mercado nacional. No final do período de amostragem, o instrumento calcula automaticamente a média ponderada pelo tempo, a intensidade do ruído e outras métricas de interesse para análise do sinal acústico. A legislação vigente exige que usuários desses instrumentos de medição utilizem uma amostragem pessoal representativa quando os trabalhadores se deslocam com frequência e/ou quando o nível de ruído é variável. 


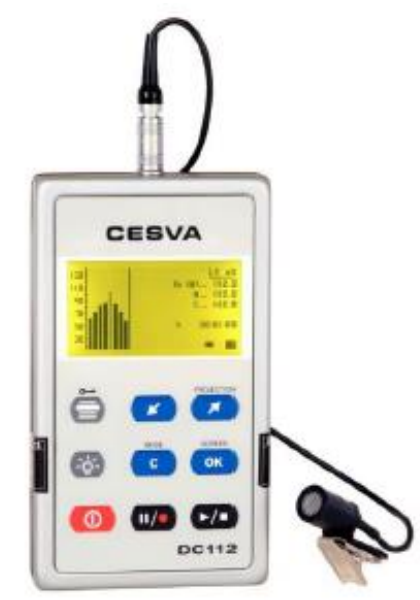

Figura 5: Dosímetro CESVA DC112

Fonte: https://www.3rhsec.com/equipamentos.html

O medidor de nível de som integrado faz medições do nível de pressão de som a partir do resultado da média linear da pressão de som quadrática instantânea ao longo do tempo de medição. A referida medição é denominada nível de pressão sonora equivalente contínuo e é designada por Leq. Este tipo de medidor de nível de som permite que as medições sejam feitas em intervalos de tempo de minutos ou horas. Normalmente, as medições são feitas utilizando-se a ponderação A, caso em que a designação correta seria LAeq. A Figura 6 ilustra uma versão mais elaborada de sonômetro calibrado (CESVA modelo SC-420) para medição da pressão sonora, com capacidade para medir o nível de som classe 1 e analisar o espectro de banda de 1/3 oitava. Para assegurar a confiabilidade metrológica dos resultados das medições realizadas in loco, o Anexo A documenta e comprova a rastreabilidade do sonômetro CESVA SC-420.

O ruído é caracterizado por um conjunto reduzido de valores, em particular o domínio das frequências de interesse dividido em bandas de oitava ou de um terço de oitava. Numa banda de oitava a frequência limite superior é o dobro da frequência limite inferior [66]. 


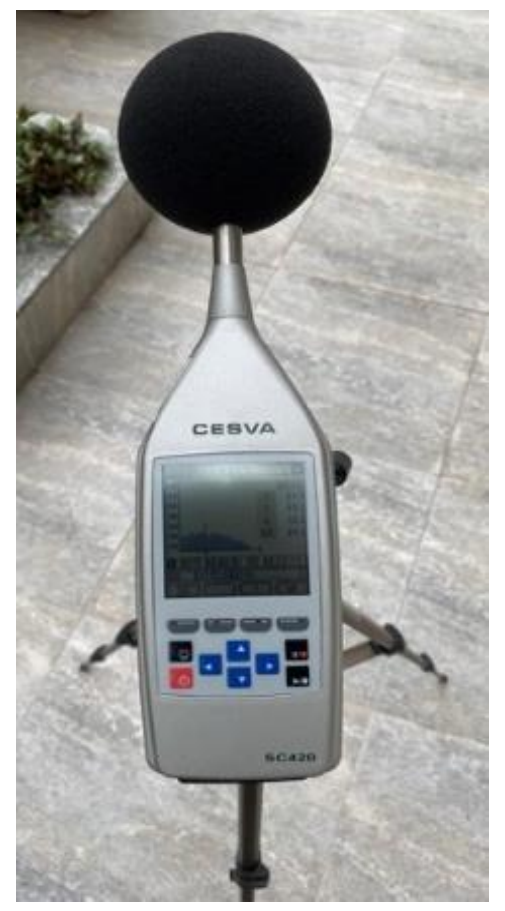

Figura 6: Sonômetro classe 1 (CESVA modelo SC-420)

Fonte: Relatório do P\&D Light/Aneel 00382-0128/2019 (Frota et al., 2021)

\subsection{2}

\section{Confiabilidade metrológica das medições realizadas}

As medições da pressão sonora foram realizadas com um sonômetro CESVA SC420 (Type 1 sound level meter), calibrado por um laboratório acreditado na Rede Brasileira de Calibração (RBC/INMETRO), cuja incerteza expandida declarada no certificado de calibração emitido é de $0,9 \mathrm{~dB}$, para um Fator de Abrangência (Coverage Factor) $k=2,00$. O certificado de calibração foi incluído no Anexo A.

\subsection{3}

\section{Visualização do campo acústico}

Com o vertiginoso avanço das tecnologias, em especial aquelas voltadas ao processamento de imagens, novas técnicas de "visualização do campo acústico" têm sido desenvolvidas, permitindo, dentre outras finalidades, observar a formação de feixes acústicos, que contribuem para a identificar a localização de fontes de ruído e orientar aplicações específicas de interesse.

A partir de 1994, avanços expressivos foram feitos nessa área do conhecimento, com a introdução do conceito fundamental de beamforming técnica de processamento de sinal baseada na formação de feixe acústico, obtida por meio de microfones montados no chamado campo distante da fonte de ruído 
[12]. Por cerca de 20 anos, este conceito encontrou aplicações no processamento de sinais de rádio [13], em antenas de fonte orientáveis [14] e em observações sísmicas [15], mas foi somente em 1974 que a solução de formação de feixes foi documentada por Billingsley [16]. Após o trabalho de Billingsley, Fisher et al. (1977) surgiram com um conceito semelhante, que fundamentou a técnica que denominou de "método da correlação polar" [17]. Uma comparação das duas abordagens foi então realizada por Billingsley [18]. Em artigo recente, Chiariotti et. Al (2019) [19] apresentam uma evolução histórica das técnicas utilizadas para viabilizar a identificação das fontes de ruído mais impactantes no sinal acústico.

Ao longo dos anos, diferentes algoritmos e abordagens foram desenvolvidos, cujo nível de complexidade aumentou de forma expressiva, contribuindo para a melhoria da aquisição de dados e sua computação. Os avanços que resultaram dos algoritmos de beamforming instrumentam, hoje, códigos de identificação do retardamento de fase, virtualmente focando a matriz de sensores para uma direção particular (propagação de onda plana) ou para um ponto particular no espaço (propagação de onda esférica). Como resultado desses avanços, o mercado especializado de instrumentos sonoros oferece, nos dias de hoje, acesso a sofisticados equipamentos, que permitem, em tempo real, o processamento do complexo sinal acústico produzido por um arranjo de múltiplos microfones estrategicamente posicionados espacialmente. Enquanto uma matriz produz uma amostra espacial de um campo sonoro, um algoritmo de formação de feixes realiza uma operação de filtragem espacial que torna possível mapear a distribuição das fontes a uma certa distância da matriz e, portanto, localizar as mais intensas.

No curso de desenvolvimento do projeto de P\&D (Light/Aneel 003820128/2019, "Controle de níveis de pressão sonora em subestação de energia”) [4], uma câmara acústica tridimensional (GFAITech, modelo STARPROGF, NoiseImage), processa, em tempo real, os sinais acústicos captados por 48 microfones montados em posição espacial pré-determinada (na forma de anel). Fazendo uso de um algoritmo de formação de feixe acústico, este sofisticado instrumento permite a captura de sinal da matriz em uma direção particular, dando origem a um sinal direcionado, assim identificando de onde se originam os ruídos mais impactantes, i.e., de intensidade mais elevada. O sinal se mostra mais intenso quando mais próxima a câmera acústica estiver da direção de propagação da fonte.

A Figura 7 mostra o anel de 48 microfones da câmara acústica tridimensional, direcionado para um dos transformadores de alta-tensão da subestação de energia elétrica que é objeto do projeto de $\mathrm{P} \& \mathrm{D}$. Nesse caso, em que múltiplos microfones são utilizados na formação de feixes acústicos (beamforming) o sistema de medição é extremamente complexo, já que requer processamento em tempo real de um grande número de sinais acústicos, resultando num extenso processamento dos sinais acústicos registrados. 


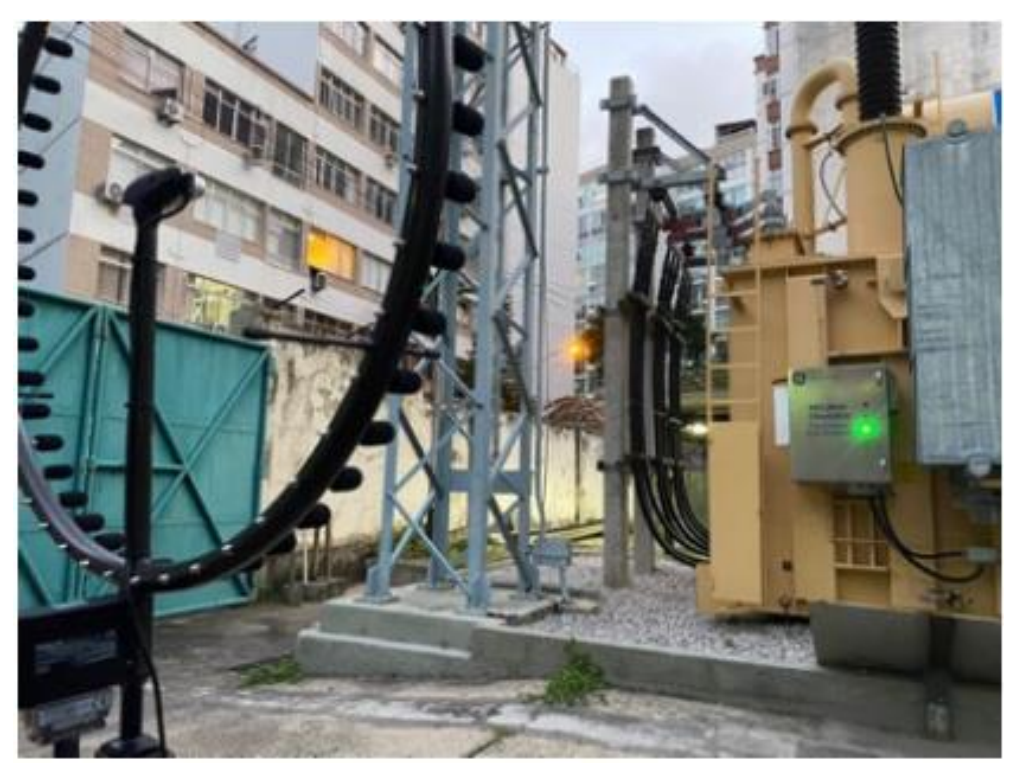

Figura 7: Câmera 3D (48 microfones) direcionada para o alvo de medição Fonte: Relatório do P\&D Light/Aneel 00382-0128/2019 (Frota et al., 2021)

O uso desse equipamento possibilita mapear as principais fontes geradoras das emissões acústicas no ambiente interno da subestação no contexto de um estudo técnico detalhado das emissões sonoras, visualizando com facilidade as situações acústicas por meio de imagens superpostas e valores expressos em $\mathrm{dB}$ e em $\mathrm{dB}(\mathrm{A})$, quando se deseja enfatizar o resultado da medição refere-se a uma ponderação pela Curva A.

Para ilustrar a sofisticação deste sistema 3D de visualização do campo acústico, a Figura 8 ilustra o resultado de uma medição típica, tendo como alvo um dos transformadores em operação na Subestação de Energia Leme, operada pela Concessionária de Energia Light SESA S/A. A visualização do campo acústico constituiu-se em ferramenta extremamente eficaz para identificar "vazamentos acústicos" em áreas críticas da subestação estudada no projeto de $\mathrm{P} \& \mathrm{D}$ associado ao qual esta pesquisa de mestrado se desenvolveu. A técnica é aqui citada pela sua relevância estratégica para orientar o posicionamento de barreiras acústicas quando aplicáveis, embora não foi utilizada no desenvolvimento desta pesquisa de mestrado. 


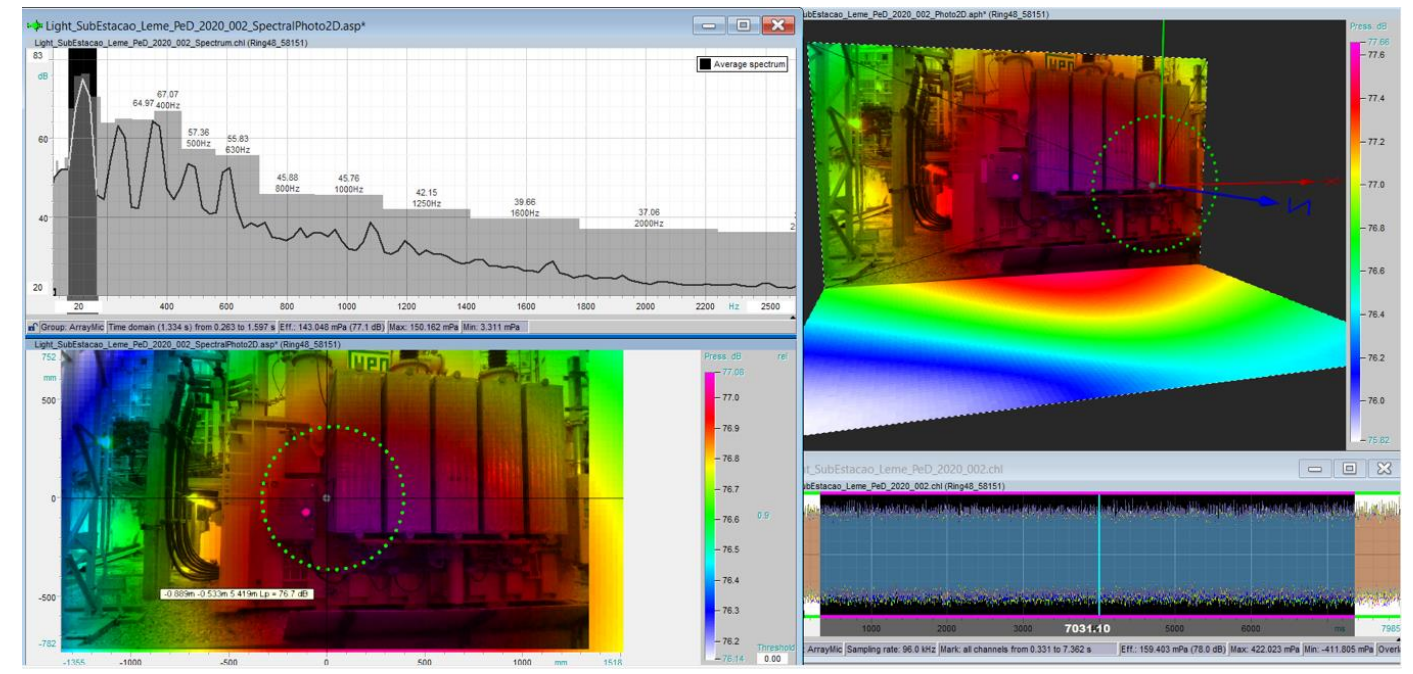

Figura 8: Exemplo de imagem de visualização do campo acústico

(Câmera girada de $30^{\circ}$ à esquerda (banda: $125 \mathrm{~Hz}$ sem ponderação; Leq = 76,7

dB) Fonte: Relatório do P\&D Light/Aneel 00382-0128/2019 [4]

As imagens mostram detalhes da resposta da câmera acústica focada em duas posições, diretamente voltada para a face frontal do transformador e na posição girada de $30^{\circ}$ para a esquerda, com e sem ponderação da curva A. Os resultados indicam um valor de Leq $=76,7 \mathrm{~dB}$, para toda a faixa de medição, com banda de $125 \mathrm{~Hz}$, sem ponderação da Curva A.

A Tabela 3 descreve as principais características da Câmera Acústica 3D, Ring48 AC Pro/48 Chanel system para medições 3D.

Tabela 3: Características funcionais da câmera 3D (48 microphones)

Fonte: Relatório do P\&D Light/Aneel 00382-0128/2019 [4]

\begin{tabular}{|c|c|}
\hline Função & Características funcionais \\
\hline Ambiente operacional & $\begin{array}{l}0^{\circ} \mathrm{C} \text { - } 35^{\circ} \mathrm{C} \text {, até } 80 \% \mathrm{RH} \text { (RealSense) e } 0^{\circ} \mathrm{C}-45^{\circ} \mathrm{C} \text {, até } 80 \% \\
\mathrm{RH} \text { (Baumer) }\end{array}$ \\
\hline Microfones & $\begin{array}{l}\text { Cápsula do condensador de eletreto + pré-amplificador de } \\
\text { design especial }\end{array}$ \\
\hline Resposta de frequência & $\begin{array}{l}100 \mathrm{~Hz}-15 \mathrm{kHz}(<0,5 \mathrm{~dB}) 20 \mathrm{~Hz}-20 \mathrm{kHz}(<3 \mathrm{~dB}) \text { Opcional: } \\
\text { Baumer VLG-22C }\end{array}$ \\
\hline Nível de ruído & $27 \mathrm{~dB}(\mathrm{~A})$ \\
\hline Sensibilidade & $20 \mathrm{mV} / \mathrm{Pa}$ \\
\hline Canais & 48. \\
\hline Distância de medição recomendada & $>0,5 \mathrm{~m}$ \\
\hline Faixa de mapeamento acústico & $12 \mathrm{~dB}-130 \mathrm{~dB}$ \\
\hline $\begin{array}{l}\text { Frequências de mapeamento } \\
\text { recomendadas }\end{array}$ & $164 \mathrm{~Hz}-20 \mathrm{kHz}(60 \mathrm{kHz})$ \\
\hline Faixa dinâmica * & $8 \mathrm{~dB}-11 \mathrm{~dB}$, até $50 \mathrm{~dB}$ \\
\hline
\end{tabular}

Este equipamento viabiliza a medição de emissões de fontes sonoras pela visualização em escala de cor, com graduação em distintos tons, permitindo quantificar a intensidade da pressão sonora, potência sonora, espectro em frequência e o espectrograma em diversas direções, sentidos e distâncias. 
Incontestavelmente, a câmara acústica 3D é uma ferramenta eficaz e inovadora para detecção de fontes de emissão acústica, "vazamentos acústicos", falhas e controle da qualidade de outros instrumentos de medição acústica.

O software de processamento do equipamento possibilita avaliar os efeitos de supressão de fontes e avaliar estratégias de medição de controle, fornecendo resultados em índices acústicos normalizados. Possibilita, também, a solução de problemas de médio e grande porte, de grande complexidade, permitindo identificar, reconhecer e quantificar as emissões sonoras. Fornece o mapa acústico em duas e três dimensões, na direção de orientação da Câmera, em função da fonte de interesse. 


\section{3 Legislação ambiental aplicável ao controle acústico}

No senso comum, a palavra ruído significa barulho, som ou poluição sonora não desejada. No processamento de sinais o ruído pode ser entendido como um sinal aleatório, sendo importante a relação Sinal/Ruído na comunicação. Na teoria da informação o ruído é considerado como portador de informação [67].

O ruído possui impacto na saúde, tema que nos últimos anos tem merecido a atenção de estudiosos em níveis nacional e internacional e sido objeto de rigorosa regulação ambiental. A poluição sonora passou de contravenção para crime ambiental, caso constatada por laudos técnicos reconhecidos, constituindo-se em um dos principais fatores de degradação da qualidade de vida de pessoas que habitam o ambiente urbano. $\mathrm{O}$ direito ao repouso está consagrado constitucionalmente e deve ser compatibilizado com o direito à livre iniciativa econômica com o levantamento do seu impacto no entorno de locais onde a pressão sonora excede os limites da legislação ambiental. Neste contexto cresce a necessidade da elaboração de estudos de impacto ambiental, com mapas de ruído e ferramentas de cálculo homologadas, em conformidade à norma ISO 9613:1996 [22].

\section{1 \\ Normas relacionadas ao tema da pesquisa}

No que concerne às fontes de incômodo e estudo de impacto, no Brasil, a norma aplicável que trata de sons específicos é a ABNT NBR 16.313:2014 [32], que define a terminologia aplicável ao estudo da acústica e a definição dos descritores acústicos de interesse. Já a norma ABNT NBR 10.151:2019 define o critério de comodidade em função da proximidade da fonte sonora, sendo utilizada neste trabalho para definir critérios de medição para classificação de emissões tonais ou impulsivas.

\subsection{1}

Normas internacionais relacionadas ao tema da pesquisa

As atribuições e competências referentes à prevenção do ruído acústico na Europa foram transferidas para os órgãos municipais, com a ideia de regular e concretizar a forma de exercício dos poderes de fiscalização dos municípios, notadamente no que concerne à prevenção e controle das várias fontes de produção de ruído susceptíveis de causar incômodo durante todas as suas fases de exposição. 
Então, para o estudo de impacto ambiental e da poluição sonora faz-se absolutamente necessário conhecer não apenas as fontes internas e externas, mas, também, as demais fontes impactantes que se fazem presentes no ambiente em estudo. Essas fontes sonoras externas - também denominadas de fontes de ruído de fundo - devem ser identificadas e adequadamente quantificadas. Embora a norma ABNT NBR 10151:2019 [7] não especifique o tempo de medição e, tampouco, o número de réplicas e de amostras, cabendo esta decisão ao profissional habilitado e capacitado, a norma recomenda que a análise do grau de impacto seja fundamentada em acompanhamento contínuo de 12 a 24 horas. Estes procedimentos foram incorporados à norma brasileira com base na orientação da norma internacional ISO 1996:2016 [24], aplicável à avaliação de ruído ambiental. Mais abrangente, a norma internacional recomenda que medições da pressão sonora sejam replicadas em mais de um dia por semana, incluindo o final de semana, quando as pessoas se fazem mais presentes em sua residência.

Dentre o acervo de normas internacionais, pelo seu interesse ao desenvolvimento deste trabalho, destacam-se as normas elaboradas pela International Electrotechnical Commission (IEC) e pela International Organization for Standardization (ISO), a saber:

- IEC 61094:2016 (Electroacoustics - Measurement microphones - Part 5: Methods for pressure calibration of working standard microphones by comparison) [26],

- IEC 61260:1995 (Electroacoustics - Octave-band and fractional octaveband filters) [27],

- IEC 61672:2013 (Electroacoustics - Sound level meters) [28],

- ISO 1996:2016 (Acoustics - Description, measurement and assessment of environmental noise) [24], e

- ISO 140-10:1991 (acoustics - measurement of sound insulation in buildings and of building elements — part 10), que trata das medições laboratoriais de isolamento acústico aerotransportados de pequenos elementos de construção [29].

Mais especificamente, a norma internacional ISO 15667:2000 [25] foi preparada pelo Comitê Técnico ISO/TC 43, Acústica, Subcomitê SC 1, Ruído. Esta norma menciona que caixas acústicas e cabines fornecem uma redução do som transportado pelo ar no caminho de propagação da máquina (ou um conjunto de máquinas) para as estações de trabalho próximas ou para o ambiente. Esta norma descreve os critérios que determinam o desempenho acústico de gabinetes e cabines levando em consideração os aspectos operacionais.

Já a norma ISO 1996-1:2016 [24] define as quantidades básicas a serem usadas para a descrição de ruído em ambientes comunitários e descreve os procedimentos básicos de avaliação. Também especifica métodos para avaliar o ruído ambiental e fornece orientação sobre como prever a resposta potencial de incômodo de uma comunidade à exposição de longo prazo de vários tipos de ruídos ambientais, mas não especifica limites para ruído ambiental. No entendimento desta norma, as fontes 
de som podem ser avaliadas em separado ou em várias combinações. A aplicação do método para prever a resposta ao incômodo causado pelo ruído é limitada às áreas onde as pessoas residem e a questões relacionadas ao uso de longo prazo da terra.

A resposta dos habitantes de uma comunidade quanto ao ruído percebido pelas fontes sonoras presentes pode variar de pessoa-a-pessoa. O termo "nível de classificação" é usado para descrever previsões do que a norma denomina "som físico" ou medições realizadas com base em um ou mais ajustes adicionados. Com base nesses níveis de classificação, a resposta da comunidade, no longo prazo, pode ser estimada.

Os sons são avaliados isoladamente ou em combinação, permitindo a consideração, quando considerados necessários pelas autoridades responsáveis pelo controle das características especiais de sua impulsividade, tonalidade, conteúdo de baixa frequência e, para as diferentes características do ruído do tráfego rodoviário, outras formas de ruído oriundo de transporte (e.g., ruído de aeronave) e de atividade industrial.

A norma ISO 140-10:1991 [29] refere-se à Acústica - Medição de isolamento acústico em edifícios e de elementos de construção. A Parte 10 da norma trata de medições laboratoriais de isolamento acústico aerotransportado de pequenos elementos de construção. Esta norma aplica-se a elementos de construção, excluindo janelas e portas, com uma área inferior a $1 \mathrm{~m}^{2}$ e que transmitem som entre duas divisões adjacentes ou entre uma sala e o ar livre independentemente dos elementos de construção contíguos.

\subsection{2 \\ Normas brasileiras relacionadas ao tema da pesquisa}

A Associação Brasileira de Normas Técnicas (ABNT) é o organismo normalizador brasileiro responsável pela elaboração das normas acústicas no território nacional, sendo elas fundamentais para orientar projetos acústicos eficientes. Sem perder de vista o entendimento do caráter voluntário da normalização, uma norma técnica visa elaborar recomendações capazes de assegurar a qualidade da solução do problema em questão, orientando o seu planejamento. Comumente, as recomendações de uma norma (ou de sua parte) podem ser incorporadas em uma regulação específica, atribuindo à recomendação normativa um caráter de compulsoriedade.

Dentre as Normas Brasileiras de interesse ao tema desta dissertação, destacamse as normas, a seguir, caracterizadas:

- ABNT NBR 10151:2019 - Acústica - Medição e avaliação de níveis de pressão sonora em áreas habitadas - Aplicação de uso geral [7]. Esta norma determina o procedimento para medição e avaliação de níveis de pressão sonora em ambientes destinados à ocupação humana, ou seja, trata de forma 
geral das áreas internas e externas de edificações com emissão sonora aérea ou de vibração. O texto regulamenta também que o ruído em áreas residenciais não ultrapasse os limites estabelecidos - 55 decibels para o período diurno, das $7 \mathrm{~h}$ às $20 \mathrm{~h}$, e 50 decibels para o período noturno, das 20 $\mathrm{h}$ às $7 \mathrm{~h}$.

- ABNT NBR 10152:2017 - Acústica - Níveis de pressão sonora em ambientes internos a edificações [31]. Esta norma estabelece o procedimento para execução de medições de níveis de pressão sonora em ambientes internos a edificações. Portanto, ela é um complemento para a ABNT NBR 10151:2019 [7]. Nela encontram-se os valores de referência para os diversos procedimentos relacionados às medições internas.

- ABNT NBR 16313:2014 - Acústica - Terminologia [32]. Esta norma estabelece os termos e definições em acústica. Ela é sucinta, mas importante para contribuir na compreensão das demais normas.

- ABNT NBR 16425-1:2016 - Medição e avaliação de níveis de pressão sonora provenientes de sistemas de transportes - Parte 1: Aspectos gerais [33]. Esta norma estabelece a instrumentação eletroacústica a ser utilizada em medições de níveis de pressão sonora provenientes de sistemas de transportes. Também determina a calibração e o ajuste necessários no campo da instrumentação eletroacústica.

- ABNT NBR ISO/IEC 17025:2017 - Requisitos gerais para a competência de laboratórios de ensaio e calibração [34]. Esta norma é necessária aos laboratórios de ensaio e calibração para gerar o Laudo Acústico, e calibrar ferramentas de medição como o sonômetro. Dessa forma, ela é exigida para assegurar a confiabilidade dos resultados do laboratório. Também define tanto sua parte técnica como sua gestão interna.

- ABNT NBR 15575-1:2013 - Edificações habitacionais - Desempenho Parte 1: Requisitos gerais [35]. Esta norma estabelece os requisitos e os critérios de desempenho que devem garantir a segurança de edifícios habitacionais. Dessa forma, os desempenhos da qualidade acústica também são essenciais para a segurança de tais edificações, sendo que nessa norma há determinação dos requisitos necessários para essa garantia.

- ABNT NBR 15928/2011: Ensaio não destrutivo - Análise de vibrações Terminologia [40]. Esta norma define os termos empregados em vibrações mecânicas e choques.

- Norma de Higiene Ocupacional NHO 01: Avaliação da Exposição ao Ruído [41]. Esta Norma Técnica tem por objetivo estabelecer critérios e procedimentos para a avaliação da exposição ocupacional ao ruído, que implique risco potencial de surdez ocupacional.

O Sistema de Gestão Ambiental foi estabelecido pela ABNT NBR ISO 14001 [38], que tem como objetivo o controle dos processos da empresa e sua relação com o meio ambiente. Assim, a norma aborda a questão de riscos, melhoria contínua, prevenção de acidentes e redução do impacto ambiental causado pelas operações da organização. A implementação do SGA é exigida para empresas que estejam sujeitas a Política Nacional de Resíduos Sólidos (PNRS). No entanto, é necessário 
que todos os setores da empresa estejam alinhados com os objetivos do sistema de gestão ambiental.

O Sistema de Gestão Ambiental consiste em um conjunto de procedimentos de gestão, que visam tornar o processo produtivo ou prestação de serviço de uma empresa o mais sustentável possível. O SGA orienta a empresa no planejamento e execução da sua gestão em questões relacionadas ao meio ambiente, alcance de seus objetivos e indicadores ambientais e execução de monitoramento de seus processos. Assim, orientado pelo seu Sistema de Gestão Ambiental, define os seus processos críticos que impactam no meio ambiente.

\section{2}

\section{Leis relacionadas ao tema da pesquisa}

De caráter obrigatório, uma Lei é criada para estabelecer as regras que devem ser seguidas, refletindo, portanto, um princípio de ordenamento que precisa ser atendido. Do Latim "lex" que significa "lei", uma obrigação imposta. Em uma sociedade, a função das leis é fiscalizar os comportamentos e ações dos indivíduos conforme os princípios daquela sociedade.

Em consonância aos seus objetivos específicos, enquanto a elaboração de normas (recomendações técnicas) deve ser estimulada para uma pluralidade de propósitos, a regulação (fundamentada em leis) deve ser restrita para questões essenciais relacionadas à saúde, segurança, meio ambiente e defesa do consumidor.

A chamada Lei de Crimes Ambientais ou Lei da Natureza (Lei $\mathrm{n}^{\circ}$ 9.605:1998 [39]) classifica os crimes em seis tipos diferentes: (i) Crimes contra a fauna; (ii) Crimes contra a flora; (iii) Poluição ${ }^{4}$ e outros crimes ambientais; (iv) Crimes contra o ordenamento urbano e o patrimônio cultural; (v) Infrações Administrativas; (vi) Crimes de Balões. Embora seja bastante amplo o conceito de ruído, este trabalho concentra-se no estudo da poluição e outros crimes ambientais.

No contexto desta dissertação o crime por poluição e outros crimes ambientais norteiam as normas e leis apresentadas, tendo em vista o ambiente de funcionamento de subestações de energia elétrica, em particular o nível de ruído acústico imposto aos habitantes de seu entorno.

\subsection{1}

\section{Legislação federal relacionada ao tema da pesquisa}

No contexto da Legislação Federal Brasileira, possuem interesse para este estudo as seguintes resoluções do Conselho Nacional do Meio Ambiente

\footnotetext{
${ }^{4}$ A poluição sonora ocorre quando um som ultrapassa o limite auditivo normal, e pode causar diversos danos à saúde do ser humano, como o estresse e a insônia.
} 
(CONAMA) e normas técnicas brasileiras elaboradas pela Associação Brasileira de Normas Técnicas (ABNT), incluindo uma norma de higiene ocupacional e duas Leis de âmbito federal:

- Resolução CONAMA no 1/90 [36] - Estabelece critérios, padrões, diretrizes e normas reguladoras da poluição sonora,

- Resolução CONAMA no 2/90 [37] - Estabelece normas de ruído visando ao bem estar das pessoas. Cria o Programa SILÊNCIO, coordenado pelo Instituto Brasileiro do Meio Ambiente e dos Recursos Naturais Renováveis (IBAMA),

- Lei 9.605/1998 - Lei dos Crimes Ambientais [39] - Reordena a legislação ambiental quanto às infrações e punições.

Lei 12.305/2010 [42] - Institui a Política Nacional de Resíduos Sólidos (PNRS) e altera a Lei 9.605/1998 - Estabelece diretrizes à gestão integrada e ao gerenciamento ambiental adequado dos resíduos sólidos.

\subsection{2}

\section{Legislação estadual relacionada ao tema da pesquisa}

No âmbito da legislação Estadual Brasileira merecem destaque para orientar este trabalho:

- Lei Estadual no 997/76 [43]: Dispõe sobre a prevenção e o controle da Poluição do Meio Ambiente, regulamentada pelo Decreto 8468/76 e suas alterações, em especial à redação dada pelo Decreto $n^{\circ} 54.487 / 09$,

- Lei Estadual no 11.501/94 [44]: Dispõe sobre o controle e a fiscalização das atividades que gerem poluição sonora e impõe penalidades,

- Norma Técnica L.11.032 [45]: Determina o nível de ruído em ambientes internos e externos de áreas habitadas - Método de ensaio,

- Norma Técnica L.11.033 [46]: Processo prático para calcular o nível de ruído equivalente continuo,

- Norma Técnica L.11.034 [47]: Define critérios de ruído para recintos internos e edificações,

Procedimento, Decisão de Diretoria Cetesb n ${ }^{\circ}$ 215/07/E [48]: Dispõe sobre a sistemática para avaliação de incômodo causado por vibrações geradas em atividades poluidoras.

\subsection{3}

\section{Legislação municipal relacionada ao tema da pesquisa}

No contexto da legislação municipal brasileira, destacam-se para entendimento deste trabalho: 
- Lei Municipal no 11.986/96 [49]: Altera dispositivos na Lei no 11.501/94, que dispõe sobre o controle e a fiscalização das atividades que gerem poluição sonora; impõe penalidades,

- Lei Municipal $n^{\circ} 11.780 / 95$ [50]: Dispõe sobre as obrigações do Poder Público Municipal e dos proprietários ou incorporadores de edificações, no controle da poluição sonora do Município de São Paulo,

- Lei Municipal n 11.804/95 [51]: Dispõe sobre avaliação da aceitabilidade de ruídos na Cidade de São Paulo, visando o conforto da comunidade,

- Decreto Municipal $n^{\circ}$ 35.928/96 [52]: Reestrutura o Programa Silêncio Urbano - PSIU, instituído pelo Decreto n. . 34.569/94,

- Lei no 3268 [6]: institui no Município do Rio de Janeiro as condições básicas de proteção da coletividade contra a poluição sonora,

- resolução SMAC N 198 de 22 de fevereiro de 2002 [53]: dispõe sobre a padronização dos procedimentos de fiscalização da poluição sonora.

- Decreto $N^{\circ}$. 29.881, de 18 de setembro de 2008 [54]: Consolida as Posturas da Cidade do Rio de Janeiro e dá outras providências,

- Lei 1967 DE 04 de abril de 2002 [55]: Dispõe sobre o Plano Urbanístico da Região das Praias da Baía de Niterói, seu zoneamento ambiental, a implementação de políticas setoriais, a aplicação de instrumentos de política urbana e a ordenação do uso e da ocupação do solo na região.

- Lei ${ }^{\circ} 3268$ DE 29 DE AGOSTO DE 2001 [6], que altera o regulamento $\mathrm{N}^{\circ}$ 15 , aprovado pelo decreto $\mathrm{N}^{\circ} 1.601$, de 21 de junho de 1978 , e alterado pelo decreto $\mathrm{N}^{\circ} 5.412$, de 24 de outubro de 1985.

Já no que concerne aos equipamentos de medição, em conformidade à norma IEC 61672:2018, estes devem ser de Classe 1 ou 2, ou de outra classificação que possa surgir após a edição desta Lei n³268 de 29 de agosto de 2001 e cuja normatização seja formalmente admitida pela ABNT (Redação dada pela Lei ${ }^{\circ}$ 6491/2019). No âmbito desta Lei, merecem destaque os seguintes artigos:

- $\S 1^{\circ}$. Os medidores de nível de pressão sonora e seus respectivos calibradores acústicos serão calibrados em laboratório acreditado no âmbito da Rede Brasileira de Calibração - RBC ou do Instituto Nacional de Metrologia, Qualidade e Tecnologia - INMETRO, nos prazos estabelecidos na NBR 10.151 - ABNT, ou a cada dois anos, em caso de omissão da norma. (Redação dada pela Lei nº 6491/2019)

- $\$ 2^{\circ}$. A medição de sons e ruídos será realizada a partir de um metro e cinquenta centimetros da divisa do imóvel onde se encontra a fonte, respeitando-se o estabelecido pelo caput deste artigo.

- Art. $7^{\circ}$ - Deverão dispor de proteção, instalação ou meios adequados ao isolamento acústico, que não permitam a propagação de sons e ruídos para o exterior, acima do permitido, devendo esta restrição constar no alvará de licença para estabelecimento: 
- I - Os estabelecimentos recreativos, educacionais, filantrópicos, culturais, religiosos, industriais, comerciais ou de prestação de serviços, geradores de sons e ruídos;

- II - Toda e qualquer instalação de máquinas ou equipamentos;

- Art. $11^{\circ}$ - Os ruídos e sons que provenham de cerimônias, missas, reuniões, cultos e sessões religiosas no interior dos respectivos recintos serão permitidos em qualquer área de zoneamento, desde que seja respeitado o limite máximo de $75 \mathrm{~dB}$, medidos na curva "A" do decibelímetro, exclusivamente no período diurno. (Redação dada pela Lei no $3342 / 2001$ ).

A resolução SMAC N ${ }^{\circ}$ 198, de 22 de fevereiro de 2002 [53], cita os limites sonoros e o zoneamento das regiões do município do Rio de Janeiro, presentes no Art $2^{\circ}$ e $4^{\circ}$ abaixo.

- Art. $2^{\circ}$ - Após o registro da reclamação será promovida vistoria ao local indicado para medição dos níveis de ruído, de acordo com o Art. 3o da Lei 3.342/01, que acrescenta o $\S 7$ o ao Art. 14 da Lei 3.268/01, o qual dispõe que a medição deverá ser efetuada a partir do "local base de situação do cidadão reclamante".

- $\$ 1^{\circ}$. - Poderão ser considerados como local base do cidadão reclamante, a sua residência ou local de trabalho, a área próxima destes, ou à fonte de ruído, mantido no mínimo o afastamento de dois metros do limite do imóvel que contém a fonte de ruído, conforme item 5 da norma ABNT NBR 10151:2000 [7].

- $\$ 2^{\circ}$. - Para verificação dos limites de ruído de acordo com o zoneamento, serão adotados os níveis de critério de avaliação constantes da norma ABNT NBR 10151:2000 [7], conforme tabela abaixo, exceto para os cultos religiosos, cujo limite permitido é de $75 \mathrm{~dB}(\mathrm{~A})$, apenas para o período diurno, conforme determina o Art. 1o da Lei 3.342/01, que altera o Art. 11 da Lei 3.268/01.

- $\S 3^{\circ}$. - Os procedimentos de medição e correção de nível de ruído atenderão aos critérios da NBR 10151:2000.

- $\S 2^{\circ}$. - A advertência deve ser publicada em resumo no Diário Oficial.

- Art. $4^{\circ}$ - No caso de reincidência, na segunda medição será lavrado o auto de infração, acompanhado de intimação, contra-fé, a qual determinará a obrigatoriedade de adequação aos níveis de ruído legalmente permitidos que também será publicado em resumo no Diário Oficial.

- $\$ 3^{\circ}$. - Para solicitação do benefício da redução da multa, a que se refere o $\S$ $1^{\circ}$. O infrator deverá apresentar a Declaração de Adequação Sonora conforme modelo SMAC.

A Tabela 4 da Resolução especifica os níveis de critério de avaliação (NCA) para ambientes externos, de acordo com a norma ABNT NBR 10151:2000 [7], e zoneamento municipal por similaridade: 
Tabela 4: Nível de critério de avaliação para ambientes externos, em dB(A) Fonte: Norma ABNT NBR 10151:2019

\begin{tabular}{|c|c|c|c|}
\hline \multirow[t]{2}{*}{ Tipos de Áreas } & \multicolumn{2}{|c|}{$\begin{array}{l}\text { RLAeq Limites de } \\
\text { níveis de pressão } \\
\text { sonora (dB) }\end{array}$} & \multirow{2}{*}{$\begin{array}{l}\text { Zoneamento Municipal } \\
\text { (por similaridade) }\end{array}$} \\
\hline & $\begin{array}{l}\text { Período } \\
\text { Diurno }\end{array}$ & $\begin{array}{l}\text { Período } \\
\text { Noturno }\end{array}$ & \\
\hline Áreas de sítios e fazendas & 40 & 35 & $\begin{array}{l}\text { (zonas de preservação e } \\
\text { conservação de unidades de } \\
\text { conservação ambiental e zonas } \\
\text { agrícolas) }\end{array}$ \\
\hline & & & ZCVS, ZPVS, Áreas Agricolas \\
\hline $\begin{array}{l}\text { Área estritamente } \\
\text { residencial urbana ou de } \\
\text { hospitais ou de escolas }\end{array}$ & 50 & 45 & ZRU \\
\hline $\begin{array}{l}\text { Área mista, } \\
\text { predominantemente } \\
\text { residencial }\end{array}$ & 55 & 50 & ZR1, ZR2, ZR6, ZRM, ZOC \\
\hline $\begin{array}{l}\text { Área mista, com vocação } \\
\text { comercial e administrativa }\end{array}$ & 60 & 55 & $\begin{array}{l}\text { ZR3, ZR4, ZR5, ZUM, CB de } \\
\text { ZR, ZC, ZCS }\end{array}$ \\
\hline $\begin{array}{l}\text { Área mista, com vocação } \\
\text { recreacional }\end{array}$ & 65 & 55 & $\mathrm{ZT}, \mathrm{AC}, \mathrm{ZP}, \mathrm{CB}$ de $\mathrm{ZT}$ \\
\hline $\begin{array}{l}\text { Área predominantemente } \\
\text { Industrial }\end{array}$ & 70 & 60 & ZPI, ZI, ZIC, CB de ZI \\
\hline
\end{tabular}

Obs: Os níveis máximos de sons e ruídos permitidos em ZE serão verificados de acordo com os usos previstos em cada sub-zona em correlação com a tabela acima.

Nota: a resolução 198 já estabelece os limites de zoneamento conforme norma ABNT NBR 10151 de $60 \mathrm{~dB}(\mathrm{~A})$ e $55 \mathrm{~dB}(\mathrm{~A})$ e coloca a ZR3 nesses limites de Zoneamento.

- ZR 1, 2, 3- zona residencial (permite ensino em edificação exclusiva).

- ZR 4, 5-zona residencial (permite comércio em edificação mista e pequena indústria).

- ZR 6 - Residencial e agrícola.

- ZCS - zona de comércio e serviço.

O Decreto $\mathrm{N}^{\circ}$. 29.881, de 18 de setembro de 2008 [54] cita que:

- I - Período diurno (PD) - o tempo compreendido entre $7 \mathrm{~h}$ e $22 \mathrm{~h}$ do mesmo dia, exceto os domingos e feriados constantes do calendário oficial do Município, quando este período será entre 8 h e 22 h;

- II - Período noturno (PN) - o horário complementar ao período diurno, sendo o tempo compreendido entre $22 \mathrm{~h}$ de um dia e $7 \mathrm{~h}$ do dia seguinte. Respeitando a ressalva de domingos e feriados;

- Dos Níveis Máximos Permissíveis e dos Métodos de Medição de Sons e Ruídos:

- Art. $4^{\circ}$ - As atividades deverão obedecer aos níveis máximos de sons e ruídos preconizados pela norma ABNT NBR 10151:2000 [7], conforme estabelecido na tabela I do Anexo, de acordo com os períodos e as zonas em que se divide o Município. 
- $\$ 1^{\circ}$. Para as nomenclaturas de zoneamento municipal não constantes da Tabela I do Anexo, adotar-se-ão os níveis de sons e ruídos por similaridade de usos e/ou tipos de edificações, a critério do órgão competente.

- $\S 2^{\circ}$. Quando a fonte produtora de ruído e o local onde se percebe o incômodo se localizarem em diferentes zonas, serão considerados os limites estabelecidos para a zona onde se percebe o incômodo.

- Art. $5^{\circ}$. O procedimento de medição dos níveis de pressão sonora será executado por profissionais legalmente habilitados na área tecnológica, com a utilização de medidores de nível de pressão sonora de Tipo 1, seguindo o estabelecido na norma ABNT NBR 10151:2000 [7].

- $\S 1^{\circ}$. Todos os componentes dos medidores de nível de pressão sonora deverão ser devidamente calibrados, anualmente, pelo INMETRO ou por instituições acreditadas por este.

- $\$ 2^{\circ}$. A medição de sons e ruídos será realizada a partir de um metro e cinquenta centimetros da divisa do imóvel onde se encontra a fonte, respeitando-se o estabelecido pelo caput deste artigo.

- $\$ 3^{\circ}$. O microfone do aparelho medidor de nível de pressão sonora deverá ficar afastado, no mínimo, um metro e cinquenta centímetros de quaisquer obstáculos e um metro e vinte centímetros do solo, bem como guarnecido de tela/filtro de vento, quando necessário, a critério do órgão competente.

A Lei Municipal de Niterói número 1967 de 04 de abril de 2002 [55] cita que:

- Art. $1^{\circ}$ - A presente Lei dispõe sobre o Plano Urbanístico da Região (PUR) das Praias da Baía, seu zoneamento ambiental, a implementação de políticas setoriais, a aplicação de instrumentos de política urbana e a ordenação do uso e da ocupação do solo na região, sendo observadas as seguintes diretrizes:

- I - pleno desenvolvimento das funções sociais da cidade;

- II - garantia do bem-estar de seus habitantes;

- III - adequada distribuição da população, das atividades socioeconômicas e dos equipamentos urbanos e comunitários, ao espaço urbano;

- IV - integração e complementaridade das políticas de uso e ocupação do solo, meio ambiente, habitação, saneamento básico, transportes e sistema viário, serviços públicos, equipamentos urbanos e comunitários;

- V - ordenação e correção da expansão urbana;

- VI - proteção, recuperação e uso sustentável dos recursos naturais;

- VII - proteção e recuperação do patrimônio histórico, artístico, turístico, cultural e paisagístico;

- VIII - integração das áreas de ocupação informal à cidade formal;

- IX - adequação do direito de construir à função social da propriedade;

- X - aplicação de instrumentos de política urbana que regulam o uso da propriedade urbana em prol do bem coletivo, da segurança e do bem-estar dos cidadãos, bem como do equilíbrio ambiental. 
- Art. $4^{\circ}$ - O zoneamento ambiental condiciona o uso e a ocupação do solo na Região das Praias da Baía, dividindo-a em Zona Urbana e Zona de Restrição à Ocupação Urbana, esta última descrita no Anexo III e no Mapa 2 do Anexo I desta lei, e em Áreas de Especial Interesse, tratadas nesta lei.

- $\$ 1^{\circ}$ - As Áreas de Especial Interesse Urbanístico e as de Especial Interesse Social são unidades territoriais independentes integrantes da Zona Urbana, salvo exceções expressas nesta lei.

- $\$ 2^{\circ}$ - As Áreas de Especial Interesse Turístico, Paisagístico, Pesqueiro e de Preservação do Ambiente Urbano sobrepõem-se às frações urbanas ou à Zona de Restrição à Ocupação Urbana.

- $\$ 3^{\circ}$. - As Áreas de Especial Interesse Ambiental estão inseridas na Zona de Restrição à Ocupação Urbana, em caráter provisório, destinadas à criação de Unidades de Conservação Municipais e delimitação de Áreas de Preservação Permanente.

Os limites de ruído para o zoneamento de Niterói estão representados na Tabela 5.

(Dados apresentados por sub-região na região das praias da baía)

Tabela 5: Níveis máximos para emissão de sons e ruídos

Fonte: Lei Municipal de Niterói número 1967 de 04 de abril de 2002 [55]

\begin{tabular}{|c|c|c|}
\hline Fração Urbana & Período Diurno & Período Noturno \\
\hline \multicolumn{3}{|c|}{ Sub-Região Centro } \\
\hline $\begin{array}{l}\text { СТ 01, СТ 02, СТ 04-A, СТ 04B, СТ 04C, } \\
\text { СТ 10, } \\
\text { СТ 15, СТ 16, СТ 17-А, СТ 17-В }\end{array}$ & $55 \mathrm{~dB}(\mathrm{~A})$ & $50 \mathrm{~dB}(\mathrm{~A})$ \\
\hline $\begin{array}{l}\text { СТ 03, СТ 05, СТ 06-А, СТ 06-В, СТ 07,СТ 09-А } \\
\text { СТ 09-В, СТ 11, СТ 12, СТ 13, СТ 14, СТ 18-А } \\
\text { СТ } 18-\text { В, СТ 18-С, СТ 18-D, СТ 19, СТ 20, СТ } 21 \\
\text { СТ } 22\end{array}$ & $65 \mathrm{~dB}(\mathrm{~A})$ & $60 \mathrm{~dB}(\mathrm{~A})$ \\
\hline СТ 08-А, СТ08-В & $70 \mathrm{~dB}(\mathrm{~A})$ & $65 \mathrm{~dB}(\mathrm{~A})$ \\
\hline \multicolumn{3}{|l|}{ Sub-Região Icaraí } \\
\hline $\begin{array}{l}\text { IC 01, IC 02, IC 03, IC 04, IC 05, IC 06, IC 07, IC } 08 \\
\text { IC 09, IC 13, IC } 15\end{array}$ & $55 \mathrm{~dB}(\mathrm{~A})$ & $50 \mathrm{~dB}(\mathrm{~A})$ \\
\hline $\begin{array}{l}\text { IC } 10, \text { IC } 11, \text { IC } 12 \text {, IC } 14 \text {, IC 16-A, IC 16-B, IC } 17 \\
\text { IC } 18\end{array}$ & $65 \mathrm{~dB}(\mathrm{~A})$ & $60 \mathrm{~dB}(\mathrm{~A})$ \\
\hline \multicolumn{3}{|c|}{ Sub-Região Santa Rosa } \\
\hline $\begin{array}{l}\text { SR 01, SR 02, SR 03, SR 04, SR 05, SR 06, SR } 07 \\
\text { SR 08, SR } 09\end{array}$ & $55 \mathrm{~dB}(\mathrm{~A})$ & $50 \mathrm{~dB}(\mathrm{~A})$ \\
\hline \multicolumn{3}{|c|}{ Sub-Região São Francisco } \\
\hline SF 01, SF 06 & $55 \mathrm{~dB}(\mathrm{~A})$ & $50 \mathrm{~dB}(\mathrm{~A})$ \\
\hline $\begin{array}{l}\text { SF 02, SF 03-A, SF 03-B, SF-04, SF 05, SF } 07 \\
\text { SF } 08\end{array}$ & $65 \mathrm{~dB}(\mathrm{~A})$ & $60 \mathrm{~dB}(\mathrm{~A})$ \\
\hline \multicolumn{3}{|c|}{ Sub-Região Jurujuba } \\
\hline J 01, JJ02, JJ03 & $65 \mathrm{~dB}(\mathrm{~A})$ & $50 \mathrm{~dB}(\mathrm{~A})$ \\
\hline
\end{tabular}


- Art. 10 - A emissão de sons e ruídos por quaisquer atividades na Região das Praias da Baía deverá obedecer aos níveis máximos estabelecidos, por períodos e diferenciados por fração urbana, na Tabela 3.2.3-B.

- $\$ 1^{\circ}$ - Considera-se período diurno o horário compreendido entre $7 \mathrm{~h} \mathrm{e} 22 \mathrm{~h}$ do mesmo dia e período noturno o horário entre $22 \mathrm{~h}$ de um dia e $7 \mathrm{~h}$ do dia seguinte, exceto nos domingos e feriados, quando o período diurno será entre $8 \mathrm{~h}$ e $22 \mathrm{~h}$ e o noturno será entre $22 \mathrm{~h}$ de um dia e $8 \mathrm{~h}$ do dia seguinte.

- $\S 2^{\circ}$. - A medição de sons e ruídos deverá ser realizada a partir de um metro e meio da divisa do imóvel onde se encontra a fonte a ser medida, conforme as normas pertinentes em vigor, desconsiderado o ruído de fundo.

- $\$ 3^{\circ}$. - Excetuam-se do disposto no caput deste artigo as seguintes atividades, cujos ruídos e sons poderão ser permitidos independente dos níveis emitidos, em locais e horários autorizados pelo Município:

- I - exibições em logradouros públicos de escolas de samba, desfiles oficiais, propaganda eleitoral, eventos socioculturais ou recreativos de caráter comunitário, passeatas, comícios, manifestações públicas, campanhas de utilidade pública, procissões ou cortejos de grupos religiosos;

- II - obras de caráter emergencial, por razão de segurança, ou obras públicas ou privadas, desde que não passíveis de confinamento.

- $\$ 4^{\circ}$. - O uso de explosivos em pedreiras e obras seguirá critérios definidos na legislação específica. 


\section{4 \\ Critérios de seleção e caracterização das subestações estudadas}

Conforme descrito no Capítulo 1, a motivação para desenvolvimento deste trabalho resultou de uma ação cível impetrada por moradores da vizinhança de uma subestação elétrica de alta tensão (SE), que se sentiram incomodados pelo ruído acústico gerado pelo funcionamento dos transformadores, ação essa em que também alegam riscos à saúde dos habitantes do entorno da subestação. Nesse contexto, as subestações estudadas foram selecionadas com base no critério de estarem instaladas em áreas de alta densidade populacional, em região demarcada pelo Município.

A definição desse critério-filtro baseou-se no conceito de zoneamento urbano que define zoneamento como o uso da propriedade imobiliária mediante delimitação de áreas categorizadas em vista das utilizações urbanas nelas admitidas [56]. Mais especificamente, mapeia-se o espaço urbano nos municípios considerados, fixam-se as destinações possíveis de seu uso nas várias zonas delineadas da cidade, levando-se em conta perspectivas de expansão, com o propósito de assegurar condições e qualidades ambientais de vida satisfatórias [56]. Nesse contexto, a própria variedade de usos concebíveis (residencial, comercial, institucional, industrial e misto) só ganha configuração funcional perante os objetivos do zoneamento, em vista de outros fatores que servem para precisar-lhes especificadamente a fisionomia. Assim, por exemplo, a taxa de ocupação de um determinado lote, a relação entre a área do terreno e área susceptível de ser nela construída, irão normalmente influir sobre a índole do uso residencial ou da específica destinação comercial que poderá ter [56].

As zonas de densidade populacional nos centros urbanos definidas no zoneamento são contempladas entrelaçadamente às naturezas de uso, aos coeficientes de edificação, às taxas de ocupação, aos recuos exigidos das construções, sejam fronteiriços, laterais ou de fundos, ou relacionados às dimensões do lote ou ao seu alinhamento. Em outras palavras, a classificação de zoneamento leva em consideração o afastamento da edificação em relação à via pública e a outros fatores que concorrem para dar completa e real identidade ou sentido à partição da cidade em zonas de diferentes densidades urbanas.

Em observância a esse conceito de zoneamento, subestações foram selecionadas para fundamentar este estudo, que avalia o nível da pressão sonora na sua vizinhança e a sua conformidade aos limites impostos pela legislação ambiental aplicável, para cada classe de zoneamento considerada. 


\section{1}

\section{Subestações de energia elétrica selecionadas}

Dentre as dez subestações elétricas monitoradas para fundamentar o estudo (inclui a subestação Leme, foco do Projeto de P\&D [4]), sete localizam-se na cidade do Rio de Janeiro, duas em Niterói e uma em Nova Iguaçu, cujas especificações técnicas estão caracterizadas na Tabela 6 , todas em funcionamento em áreas de alta densidade populacional e em regiões demarcadas.

Tabela 6: Caracterização das subestações estudadas

\begin{tabular}{cccccc}
\hline $\begin{array}{c}\text { Subestação de } \\
\text { energia elétrica }\end{array}$ & $\begin{array}{c}\text { Concessionária } \\
\text { de energia }\end{array}$ & Município & $\begin{array}{c}\text { Potências dos } \\
\text { transformadores }\end{array}$ & $\begin{array}{c}\text { Alta/Baixa } \\
\text { tensão (kV) }\end{array}$ & $\begin{array}{c}\text { Limites de rú́do } \\
\text { nos períodos } \\
\text { diurno/noturno }\end{array}$ \\
\hline \hline Leme & $*_{\text {Light }}$ & Rio de Janeiro & $2 \times 40 \mathrm{MVA}$ & $138 / 13,8$ & $55 \mathrm{~dB} / 50 \mathrm{~dB}$ \\
São Lourenço & ${ }^{*}$ Ampla & Niterói & $3 \times 33,3 \mathrm{MVA}$ & $138 / 11,9$ & $55 \mathrm{~dB} / 50 \mathrm{~dB}$ \\
Ingá & Ampla & Niterói & $2 \times 33,3 \mathrm{MVA}$ & $69 / 11,9$ & $55 \mathrm{~dB} / 50 \mathrm{~dB}$ \\
Jardim Botânico & Light & Rio de Janeiro & $3 \times 40 \mathrm{MVA}$ & $138 / 13,8$ & $55 \mathrm{~dB} / 50 \mathrm{~dB}$ \\
Uruguai & Light & Rio de Janeiro & $3 \times 20 \mathrm{MVA}$ & $138 / 13,8$ & $60 \mathrm{~dB} / 55 \mathrm{~dB}$ \\
Humaitá & Light & Rio de Janeiro & $3 \times 20 \mathrm{MVA}$ & $138 / 13,8$ & $60 \mathrm{~dB} / 55 \mathrm{~dB}$ \\
Major Vaz & Light & Rio de Janeiro & SE de transição & $138 / 138$ & $55 \mathrm{~dB} / 50 \mathrm{~dB}$ \\
Vila de Cava & Light & Nova Iguaçu & $4 \times 3 \mathrm{MVA}$ & $25 / 13,8$ & $55 \mathrm{~dB} / 50 \mathrm{~dB}$ \\
Mackenzie & Light & Rio de Janeiro & $3 \times 40 \mathrm{MVA}$ & $138 / 13,8$ & $65 \mathrm{~dB} / 55 \mathrm{~dB}$ \\
Santo Antônio & Light & Rio de Janeiro & $6 \times 40 \mathrm{MVA}$ & $138 / 13,8$ & $65 \mathrm{~dB} / 55 \mathrm{~dB}$ \\
\hline
\end{tabular}

*Light: Light Serviços de Eletricidade S.A. Ampla: ${ }^{\star \star}$ Ampla Energia e Serviços S.A.

A imagem de satélite da Figura 9 posiciona em um mapa parcial do Estado do Rio de Janeiro as dez subestações elétricas selecionadas para o estudo. 


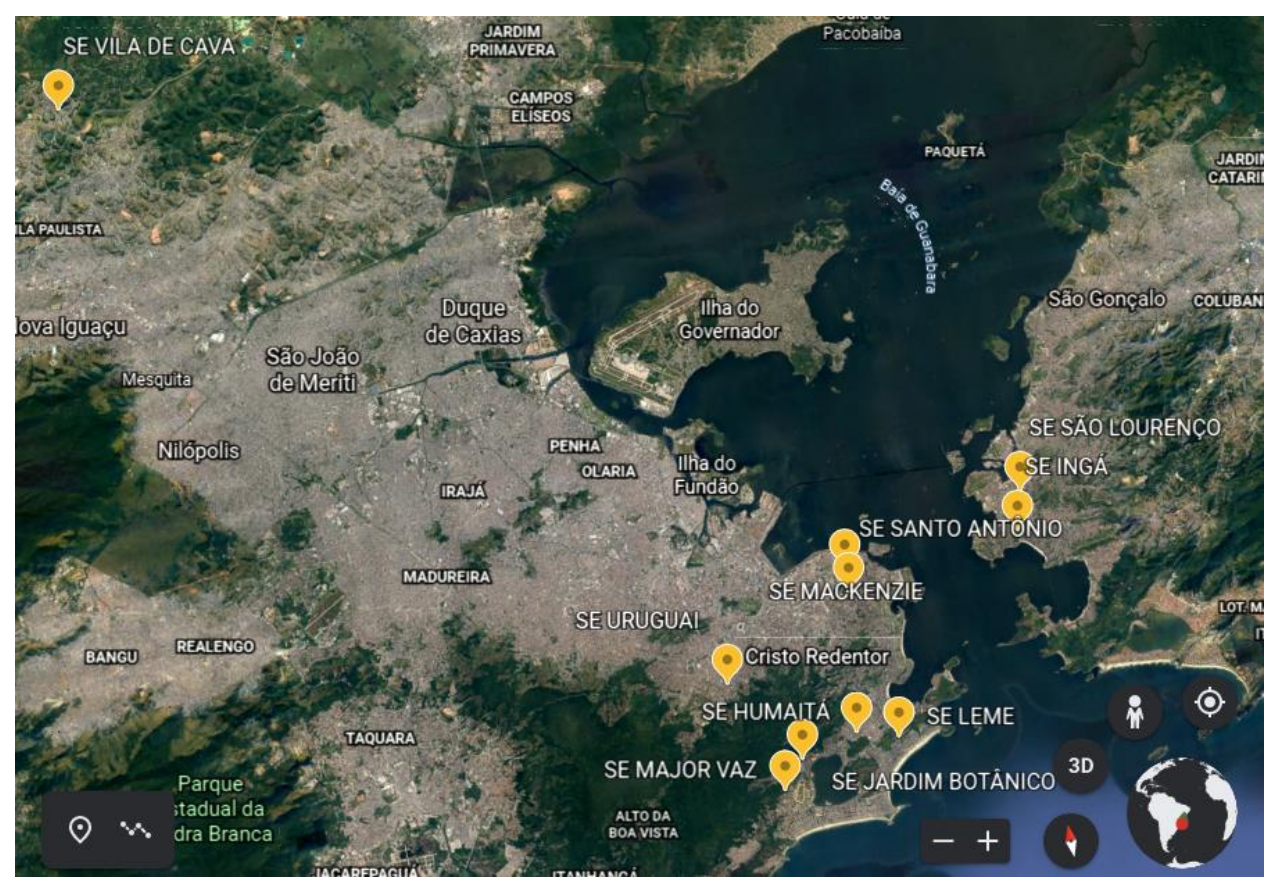

Figura 9: Subestações elétricas selecionadas

\section{2 \\ Detalhamento das subestações}

O zoneamento, densidade populacional e localização das subestações compõem as variáveis utilizadas para caracterizar o estudo. As dez subestações foram selecionadas em regiões de grande densidade populacional, levando-se também em consideração o zoneamento e a legislação ambiental, que define os limites de pressão sonora em cada caso. Diferentes pontos de medição foram definidos para documentar o campo acústico em posições críticas no entorno da subestação, mais especificamente, o ponto mais próximo dos transformadores, o ponto em frente ao portão de acesso à subestação e outro ponto criteriosamente selecionado na proximidade de potenciais reclamantes, devidamente caracterizados com base na distância da fonte primária de ruído (transformadores) e diretividade sonora.

\subsection{1}

\section{Caracteristicas das subestações}

A Tabela 7 identifica a subestação pelo local de seu funcionamento (bairro da cidade) e caracteriza aspectos relevantes relacionados ao seu enquadramento no zoneamento urbano do referido bairro. Essas informações caracterizam o entorno das subestações estudadas. 
Tabela 7: Caracterização das subestações estudadas

\begin{tabular}{|c|c|c|c|c|c|c|c|}
\hline Subestação & Bairro & Zoneamento & $\begin{array}{c}\text { Área Total } \\
\text { (ha) }\end{array}$ & $\begin{array}{c}\text { Área } \\
\text { Construída } \\
\left(\mathrm{m}^{2}\right)\end{array}$ & $\begin{array}{c}\text { Densidade de } \\
\text { área } \\
\text { construída } \\
\left(\mathrm{m}^{2} / \mathrm{ha}\right) \\
\end{array}$ & $\begin{array}{l}\text { Total de } \\
\text { residentes }\end{array}$ & $\begin{array}{l}\text { Densidade } \\
\text { Populacional } \\
\text { (pessoas/ha) }\end{array}$ \\
\hline Leme & Copacabana & ZR2 & 84 & 927609 & 11056 & 14799 & 176 \\
\hline São Lourenço & Niterói & CT-18B & 115 & 1310000 & 11391 & 8209 & 63 \\
\hline Ingá & Niterói & IC 04 & 73 & 710000 & 9726 & 16592 & 234 \\
\hline Jardim Botânico & Jardim Botânico & ZR2 & 267 & 1049533 & 3929 & 18009 & 67 \\
\hline Uruguai & Tijuca & ZR3 & 591 & 12133672 & 20543 & 163648 & 277 \\
\hline Humaitá & Botafogo & ZR3 & 70 & 1226362 & 17508 & 13285 & 190 \\
\hline Major Vaz & Gávea & ZR1 & 149 & 1059822 & 7119 & 16003 & 107 \\
\hline Vila de Cava & Vila de Cava & ZR6 & 328 & 280000 & 854 & 8876 & 27 \\
\hline Mackenzie & Centro & $\mathrm{AC1}$ & 109 & 1344162 & 12309 & 13108 & 120 \\
\hline Santo Antônio & Centro & $\mathrm{AC2}$ & 489 & 12872936 & 26342 & 25508 & 52 \\
\hline
\end{tabular}

\subsection{2}

\section{Pontos de medição e suas características}

A Tabela 8 define o total de pontos de medição para cada uma das dez subestações estudadas, definindo a distância relativa $\mathrm{D}(\mathrm{m})$ de cada ponto de medição (local de posicionamento do sonômetro) em relação à fronteira (muro divisório) mais próxima da subestação estudada. Esta distância D caracteriza o afastamento do sonômetro utilizado para realizar as medições da pressão sonora, medida perpendicularmente ao muro divisório da subestação. Na realidade esta é uma medida aproximada, realizada com uma trena, cujo objetivo é definir a posição do ponto de medição no entorno da subestação. Trata-se de um valor aproximado que não interfere no resultado da medição e tampouco na análise acústica pretendida. Todas as medições da pressão sonora realizadas no entorno da subestação foram realizadas mantendo-se o sonômetro a uma altura de 1,50 $\mathrm{m}$ do chão. 
Tabela 8: Caracterização dos pontos de medição

\begin{tabular}{|c|c|c|c|}
\hline Subestação & $\begin{array}{l}\text { Ponto de } \\
\text { Medição }\end{array}$ & $D(m)$ & Caracterização do ponto de medição no entorno da subestação \\
\hline \multirow{8}{*}{ Leme } & P.Med \#1 & 1,00 & A $1 \mathrm{~m}$ da face externa do portão de acesso \\
\hline & P.Med \#2 & 12,00 & No portão da igreja, na entrada principal da subestação (mascaramento ativado). \\
\hline & P.Med \#3 & 12,00 & Em frente ao edifício número 16, na Rua Guimarães Natal \\
\hline & P.Med \#4 & 12,00 & Na posição de maior reflexão, em frente à Igreja Bathesda, R. Guimarães Natal. \\
\hline & P.Med \#5 & 4,50 & No início da Travessa Guimarães Natal, de frente para os transformadores \\
\hline & P.Med \#6 & 3,20 & Em frente ao muro da Subestação do Hostel 4U, na Travessa Guimarães Natal. \\
\hline & P.Med \#7 & 15,90 & Em frente ao edifício número 7, na Travessa Guimarães Natal. \\
\hline & P.Med \#8 & 22,04 & Em frente ao edifício número 10, na Travessa Guimarães Natal. \\
\hline \multirow{4}{*}{$\begin{array}{c}\text { São } \\
\text { Lourenço }\end{array}$} & P.Med \#1 & 2,00 & A 2 m da face externa do portão traseira de acesso à subestação. \\
\hline & P.Med \#2 & 13,00 & Em frente ao local de Baiano Car, a 13 m da face externa do muro da subestação. \\
\hline & P.Med \#3 & 8,00 & Ao lado Locadora Movida, a 8 m do da face externa do muro lateral da subestação. \\
\hline & P.Med \#4 & 13,00 & Em frente à casa número 23 na Rua Dr. Paulo Araújo. \\
\hline \multirow{4}{*}{ Ingá } & P.Med \#1 & 2,00 & A 2 m da face externa do portão principal da subestação. \\
\hline & P.Med \#2 & 15,00 & A 15 m em frente da ventilação da subestação, possivelmente quarto de máquinas. \\
\hline & P.Med \#3 & 15,00 & Em frente à casa 26, Rua Dr. Jaime dos Santos Figueiredo a $15 \mathrm{~m}$ da subestação. \\
\hline & P.Med \#4 & 30,00 & Em Rua ao lado da casa 26, a 30 m do portão principal da subestação. \\
\hline \multirow{6}{*}{$\begin{array}{c}\text { Jardim } \\
\text { Botânico }\end{array}$} & P.Med \#1 & 2,00 & A 2 m da face externa do portão principal da subestação. \\
\hline & P.Med \#2 & 2,00 & A 2 m da face externa do muro da subestação. \\
\hline & P.Med \#3 & 2,00 & A 2 m da face externa do portão auxiliar da subestação. \\
\hline & P.Med \#4 & 10,50 & Em frente do prédio número 155 na Rua Visconde da Graça \\
\hline & P.Med \#5 & 12,00 & Em frente do prédio número 147 na Rua Visconde da Graça. \\
\hline & P.Med \#6 & 12,00 & A 12 m da face externa do portão principal da subestação. \\
\hline \multirow{7}{*}{ Uruguai } & P.Med \#1 & 2,00 & A 2 m da face externa do portão traseira de acesso à subestação. \\
\hline & P.Med \#2 & 11,30 & Em frente ao prédio no. 379 rua Dezoito de Outubro, a 11.30 m do muro da subestação. \\
\hline & P.Med \#3 & 11,30 & Em frente à casa no. 397 , rua Dezoito de Outubro, a 11.30 m do muro da subestação. \\
\hline & P.Med \#4 & 11,30 & Em frente à casa no. 405 na Rua Dezoito de Outubro, a 11.30 m do muro da subestação. \\
\hline & P.Med \#5 & 30,00 & Em frente à casa número 15 na Rua Natalina. \\
\hline & P.Med \#6 & 2,00 & A 2 m do portão frente ao ponto de ônibus em frente da subestação. \\
\hline & P.Med \#7 & 2,00 & A 2 m da face externa do portão principal da subestação. \\
\hline \multirow{6}{*}{ Humaitá } & P.Med \#1 & 2,00 & A 2 m da face externa do portão principal da subestação. \\
\hline & P.Med \#2 & 2,00 & A 2 m da cerca do muro na parte de trás da subestação. \\
\hline & P.Med \#3 & 2,00 & A 2 m da cerca da subestação diagonal ao restaurante TRAGGA. \\
\hline & P.Med \#4 & 2,00 & A 2 m da cerca da subestação, em frente da ventilação do restaurante TRAGGA. \\
\hline & P.Med \#5 & 14,00 & Em frente ao jardim do condomínio Pinheiros. \\
\hline & P.Med \#6 & 14,00 & Em frente à portaria do condomínio Pinheiros \\
\hline \multirow{6}{*}{ Major Vaz } & P.Med \#1 & 2,00 & A 2 m da face externa do portão principal da subestação. \\
\hline & P.Med \#2 & 19,50 & Em frente da escola Manuel Cicero, a 19.5 m do portão da subestação. \\
\hline & P.Med \#3 & 21,00 & Em frente à casa número 19, na rua Orsina de Fonseca a 21 m da subestação. \\
\hline & P.Med \#4 & 12,90 & Em frente à casa número 351 , na rua Major Rubens Vaz. \\
\hline & P.Med \#5 & 10,30 & Ponto a $10.30 \mathrm{~m}$, em frente da casa 414. \\
\hline & P.Med \#6 & 2,00 & Ponto a 2 m, em frente à casa 414. \\
\hline \multirow{4}{*}{$\begin{array}{c}\text { Vila de } \\
\text { Cava }\end{array}$} & P.Med \#1 & 9,11 & A 9.11 m do portão principal da subestação. \\
\hline & P.Med \#2 & 2,10 & Ponto a $2.10 \mathrm{~m}$, em frente da casa 141. \\
\hline & P.Med \#3 & 7,25 & Ponto a $7.25 \mathrm{~m}$, em frente da casa 91. \\
\hline & P.Med \#4 & 7,20 & Ponto a $7.20 \mathrm{~m}$, em frente da casa 131. \\
\hline \multirow{4}{*}{ Mackenzie } & P.Med \#1 & 3,00 & A cerca de $3 m$ do portão da subestação. \\
\hline & P.Med \#2 & 12,50 & Na Rua Alexandre Mackenzie, calçada oposta a subestação, na direção do Trafo 2 . \\
\hline & P.Med \#3 & 13,50 & Na Rua Alexandre Mackenzie número 19. \\
\hline & P.Med \#4 & 31,40 & Atrás do Trafo 2, a cerca de $5 \mathrm{~m}$, embaixo dos disjuntores. \\
\hline \multirow{3}{*}{$\begin{array}{l}\text { Santo } \\
\text { Antônio }\end{array}$} & P.Med \#1 & 15,20 & Na Rua do Senado, na calçada oposta a entrada da Subestação. \\
\hline & P.Med \#2 & 36,31 & Na esquina da Rua Pedro I com a Rua Silva \\
\hline & P.Med \#3 & 7,00 & Na entrada Inst.Criminalística Carlos Éboli, direção portão acesso da subestação. \\
\hline
\end{tabular}

D: Distância em metros entre o Ponto de medição e o muro divisório da Subestação

A Figura 10 mostra uma foto 3D de drone da Subestação Leme, enfatizando o caráter de zoneamento de alta densidade urbana que caracteriza o local de operação das subestações de energia estudadas. A linha em vermelho gerada por software especializado, permite definir trajetórias de propagação da onda acústica em ambientes confinados e a cota das edificações que circundam a subestação. 


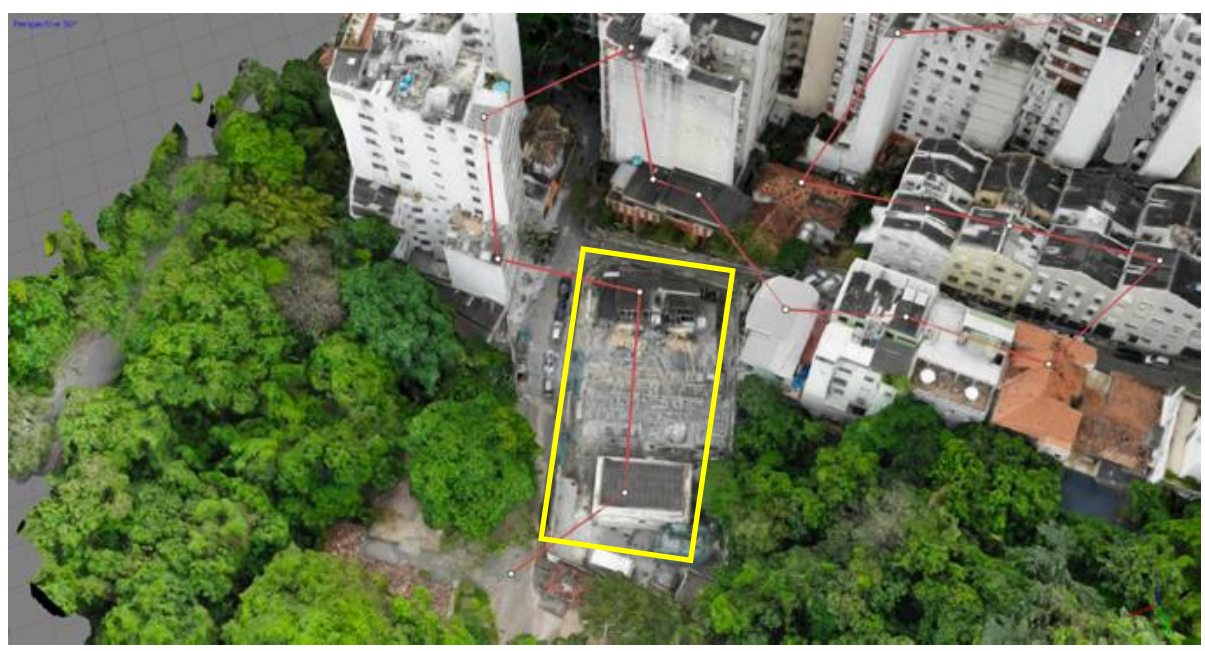

Figura 10: Posicionamento da subestação Leme trocar pela do artigo

Fonte: Relatório do P\&D Light/Aneel 00382-0128/2019 [4]

As Figuras 11 e 12 mostram imagens de satélite das subestações estudadas, mostrando as posições dos pontos de medição da pressão sonora, indicados pelos marcadores em amarelo, devidamente numerados. Esses referem-se aos diferentes pontos de medição no entorno da subestação (identificada por um retângulo na cor amarela). Separadas por munícipio, a Figura 11 mostra as subestações em operação no município de Niterói: São Lourenço e Ingá, enquanto a Figura 12 mostra vistas aéreas das oito subestações em funcionamento nos munícipios do Rio de Janeiro e Nova Iguaçu: subestações Leme, Jardim Botânico, Uruguai, Humaitá, Major Vaz, Vila de Cava, Mackenzie e Santo Antônio.
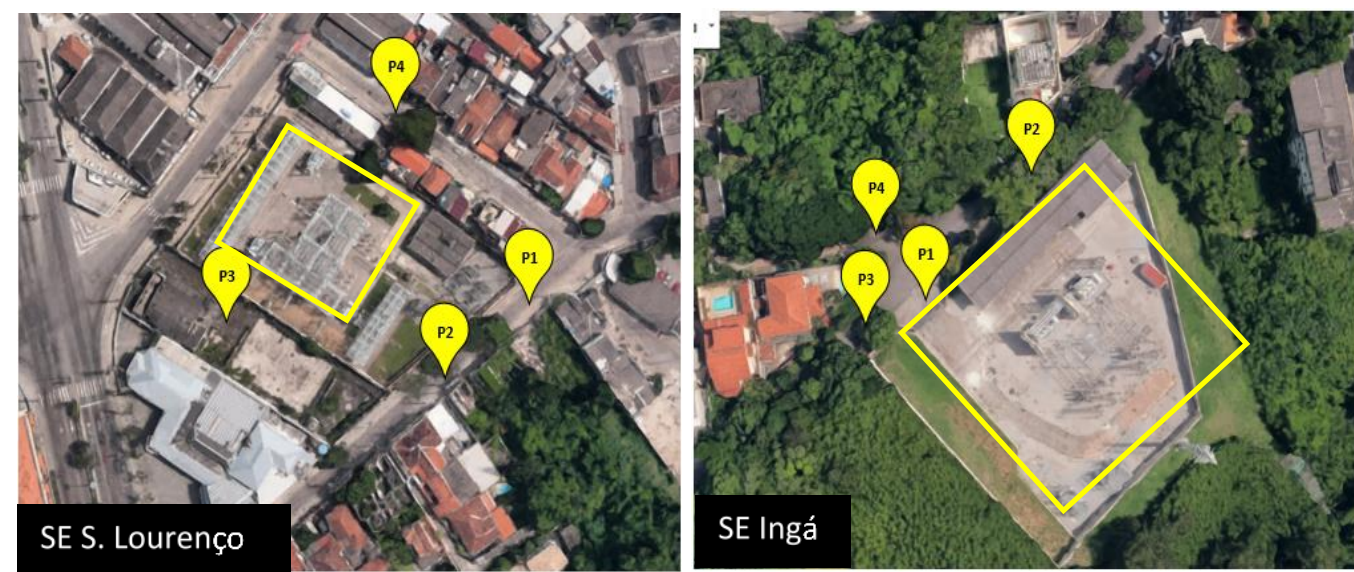

Figura 11: Caracterização dos pontos de medição (subestações em Niterói) 

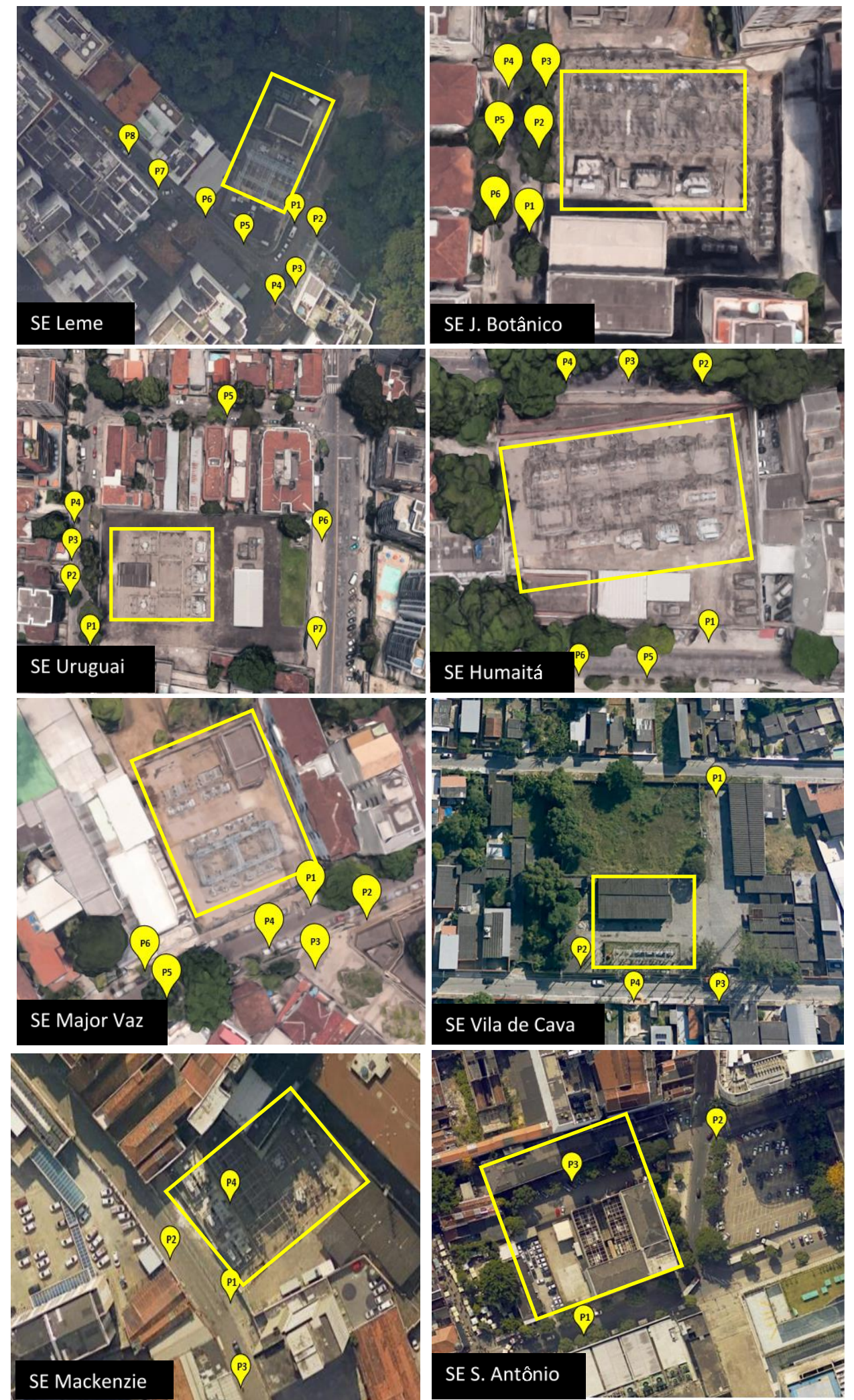

Figura 12: Imagens aéreas das subestações estudadas do Rio de Janeiro 


\section{3 \\ Resultados das medições}

Conforme descrito na seção 4.2.2, foram medidos um conjunto de pontos em dez subestações localizadas em diferentes partes do estado do Rio de Janeiro, que poderiam gerar incômodos devido ao ruído acústico gerado pelo funcionamento dos transformadores, que dependendo da intensidade pode ou não causar riscos à saúde dos habitantes do entorno da subestação. Nesse contexto, são apresentados os resultados das medições realizadas nas subestações estudadas com base na comparação com os limites de ruído mencionados na tabela 4 .

Inicialmente, a Figura 13 ilustra a evolução temporal do descritor $\mathrm{L}_{\mathrm{A}}$, definido na Eq. (3), medido no ponto 2 da subestação Leme, em períodos de 5 min, durante todo o monitoramento de longa duração. O gráfico apresenta resultados da pressão sonora medida, analisados em um gráfico de barras (Figura 14), assim permitindo interpretar a ausência da característica tonal do ruído no período de mediação diurno, para o limite de $55(\mathrm{~dB})$.

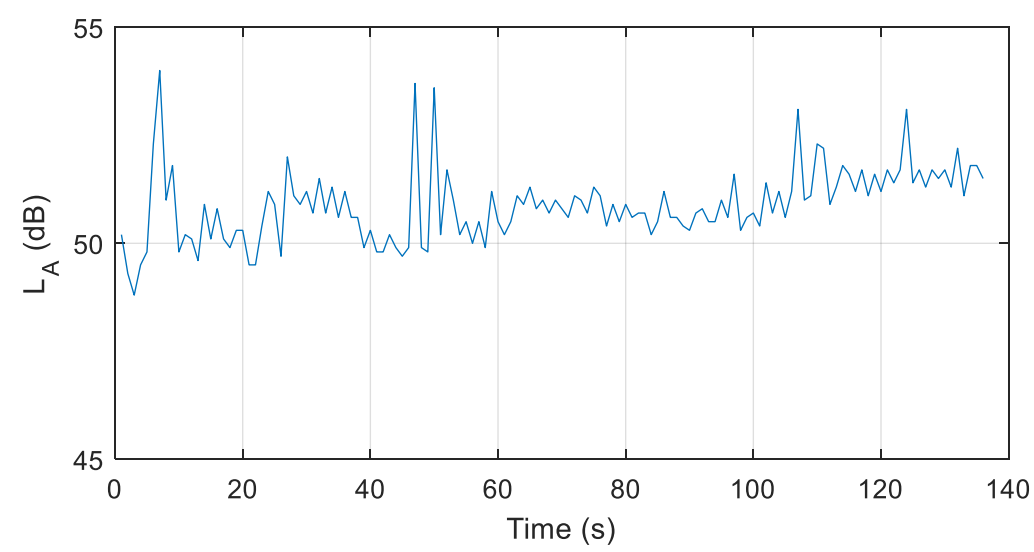

Figura 13: Níveis de pressão de ruído medidos ao longo do tempo.

Fonte: Relatório do P\&D Light/Aneel 00382-0128/2019 [4]

A Figura 14 mostra o espectro de frequência do sinal de nível de potência sonora (SPL) mostrado na Figura 13, que permite identificar a frequência característica do transformador em $125 \mathrm{~Hz}$ (devido à discretização do instrumento, a frequência de $120 \mathrm{~Hz}$ não aparece neste gráfico). 


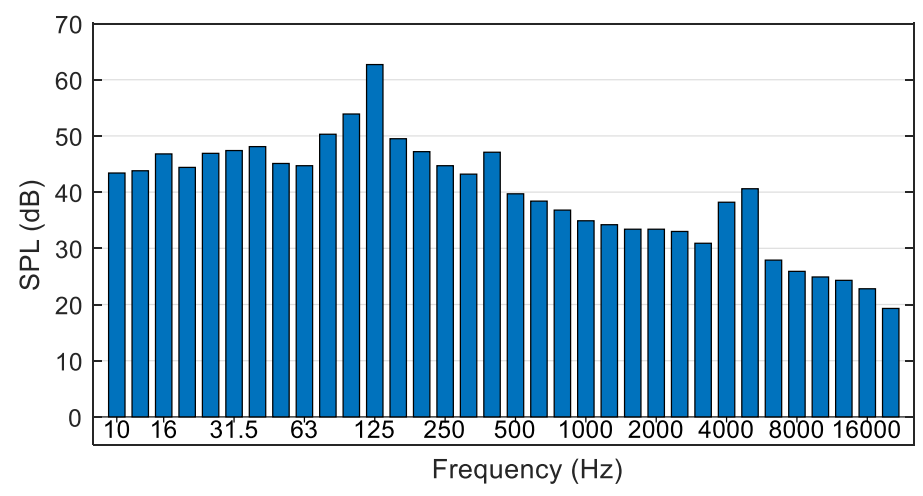

Figura 14: Espectro de frequência não mostrando características tonais

Fonte: Relatório do P\&D Light/Aneel 00382-0128/2019 [4]

No entanto, este espectro não é considerado como tendo características tonais, pois as diferenças entre a frequência central e as respectivas frequências laterais não ultrapassam os limites definidos pela norma e apresentados na Tabela 4. Em contraste com a situação acústica anterior, a Figura 15 ilustra um caso (associado ao Ponto de Medição $\mathrm{n}^{\circ}$ 4, definido no entorno da subestação Leme), que nitidamente apresenta características tonais. No caso da subestação Light/Leme, submetido a um processo mais detalhado de monitoramento da pressão sonora no âmbito do projeto de P\&D em desenvolvimento [4], as medições foram realizadas nos períodos diurno e noturno, nos períodos de verão e inverno, este último caracterizando impacto do uso intenso de ar-condicionado pelos moradores do bairro, caracterizando-se como uma expressiva fonte adicional de ruído.

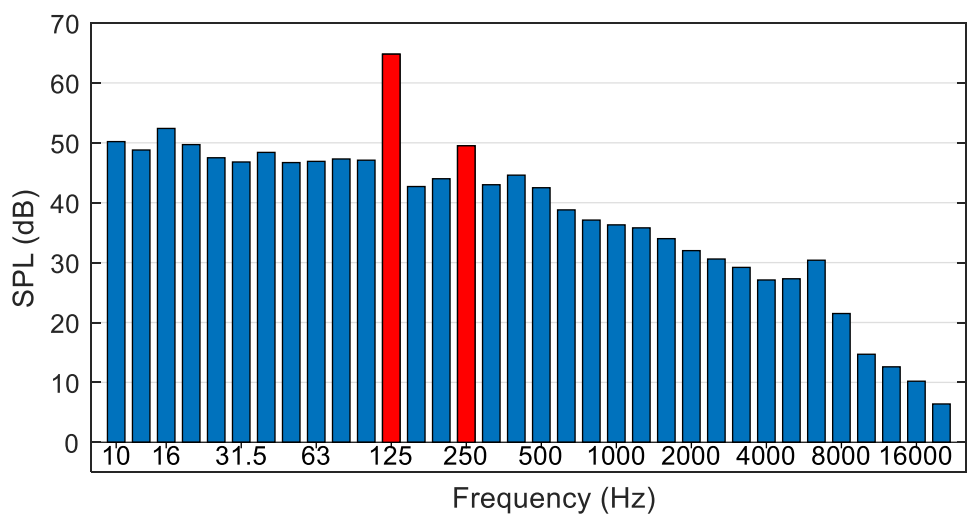

Figura 15: Características tonais

Fonte: Relatório do P\&D Light/Aneel 00382-0128/2019 [4]

A Tabela 9 resume os resultados das medições de pressão acústica realizadas nas dez subestações estudadas. 
Tabela 9: Resultados das medições para as dez subestações.

\begin{tabular}{|c|c|c|c|c|c|c|c|}
\hline Subestações & $\begin{array}{l}\text { Pontos de } \\
\text { Medição }\end{array}$ & $\begin{array}{c}\text { Distância à } \\
\text { subestação } \\
\text { (m) }\end{array}$ & $\begin{array}{l}\text { Laeq } \\
(\mathrm{dB})\end{array}$ & $\begin{array}{l}\text { L10 } \\
\text { (dB) }\end{array}$ & $\begin{array}{l}\text { L95 } \\
\text { (dB) }\end{array}$ & $\begin{array}{l}\text { LR } \\
(\mathrm{dB})\end{array}$ & Comentários \\
\hline \multirow{8}{*}{$\begin{array}{c}\text { Leme } \\
\text { (Noite de } \\
\text { Inverno) }\end{array}$} & \#1 & 1,0 & 51,8 & 252,3 & 51,1 & $\overline{51,1}$ & \multirow[b]{8}{*}{ Mascarado pela TV } \\
\hline & \#2 & 12,0 & 51,0 & 52,1 & 49,2 & 49,2 & \\
\hline & \#3 & 12,0 & 49,1 & 50,1 & 48,0 & 48,0 & \\
\hline & \#4 & 12,0 & 48,9 & 50,1 & 46,8 & 46,8 & \\
\hline & \#5 & 4,5 & 49,8 & 51,2 & 48,0 & 48,0 & \\
\hline & \#6 & 3,2 & 49,6 & 50,4 & 48,7 & 48,7 & \\
\hline & \#7 & 15,9 & 47,2 & 48,5 & 45,3 & 45,3 & \\
\hline & \#8 & 22,0 & 47,4 & 48,8 & 46,0 & $\mathrm{~N} / \mathrm{A}$ & \\
\hline \multirow{8}{*}{$\begin{array}{c}\text { Leme } \\
\text { (Dia de verão) }\end{array}$} & $\# 1$ & 1,0 & 52,7 & 53,6 & 51,3 & 51,3 & \multirow{8}{*}{$\begin{array}{l}\text { Barulho de fundo } \\
\text { Barulho de fundo } \\
\text { Barulho de fundo } \\
\text { Barulho de fundo } \\
\text { Barulho de fundo } \\
\text { Barulho de fundo }\end{array}$} \\
\hline & \#2 & 12,0 & 50,8 & 52,3 & 48,1 & 48,1 & \\
\hline & \#3 & 12,0 & 51,8 & 52,5 & 50,8 & $\mathrm{~N} / \mathrm{A}$ & \\
\hline & \#4 & 12,0 & 51,5 & 52,8 & 50,0 & $\mathrm{~N} / \mathrm{A}$ & \\
\hline & \#5 & 4,5 & 53,0 & 53,9 & 50,9 & $N / A$ & \\
\hline & \#6 & 3,2 & 54,4 & 55,3 & 53,2 & $\mathrm{~N} / \mathrm{A}$ & \\
\hline & $\# 7$ & 15,9 & 53,1 & 54,3 & 51,8 & $\mathrm{~N} / \mathrm{A}$ & \\
\hline & \#8 & 22,0 & 52,0 & 53,2 & 49,4 & $\mathrm{~N} / \mathrm{A}$ & \\
\hline \multirow{4}{*}{$\begin{array}{l}\text { São } \\
\text { Lourenço } \\
\text { (Dia) }\end{array}$} & $\# 1$ & 2,0 & 61,7 & 61,4 & 52,3 & 52,3 & \\
\hline & \#2 & 13,0 & 58,1 & 60,1 & 49,2 & 49,2 & \\
\hline & \#3 & 8,0 & 55,3 & 57,7 & 51,8 & 51,8 & \\
\hline & \#4 & 13,0 & 63,0 & 59,2 & 48,3 & 48,3 & \\
\hline \multirow{4}{*}{ Ingá (Dia) } & $\# 1$ & 2,0 & 52,0 & 52,7 & 50,8 & 50,8 & \\
\hline & \#2 & 15,0 & 55,4 & 56,4 & 52,4 & 52,4 & \\
\hline & \#3 & 15,0 & 54,4 & 57,3 & 49,3 & 49,3 & \\
\hline & \#4 & 30,0 & 48,1 & 49,9 & 46,2 & 46,2 & \\
\hline \multirow{6}{*}{ Botânico (Dia) } & $\# 1$ & 2,0 & 68,7 & 55,1 & 48,7 & 48,7 & \multirow{6}{*}{ Tonal, $630 \mathrm{~Hz}$} \\
\hline & \#2 & 2,0 & 63,0 & 55,0 & 46,9 & 46,9 & \\
\hline & \#3 & 2,0 & 59,0 & 57,2 & 45,8 & 50,8 & \\
\hline & \#4 & 10,5 & 55,7 & 57,7 & 48,0 & 48,0 & \\
\hline & \#5 & 12,0 & 62,3 & 67,5 & 48,3 & 48,3 & \\
\hline & \#6 & 12,0 & 57,7 & 62,4 & 48,1 & 48,1 & \\
\hline \multirow{7}{*}{ Uruguai (Dia) } & $\# 1$ & 2,0 & 59,5 & 58,8 & 50,0 & 50,0 & \multirow{7}{*}{$\begin{array}{l}\text { Ruído de trânsito } \\
\text { Ruído de trânsito }\end{array}$} \\
\hline & \#2 & 11,3 & 54,4 & 55,5 & 47,8 & 47,8 & \\
\hline & \#3 & 11,3 & 60,6 & 65,6 & 48,8 & 48,8 & \\
\hline & \#4 & 11,3 & 58,4 & 63,6 & 47,5 & 47,5 & \\
\hline & \#5 & 30,0 & 53,3 & 56,5 & 47,9 & 47,9 & \\
\hline & \#6 & 2,0 & 69,4 & 72,8 & 56,8 & $\mathrm{~N} / \mathrm{A}$ & \\
\hline & $\# 7$ & 2,0 & 68,4 & 71,4 & 54,7 & $\mathrm{~N} / \mathrm{A}$ & \\
\hline \multirow{6}{*}{$\begin{array}{c}\text { Humaitá } \\
\text { (Noite) }\end{array}$} & $\# 1$ & 2,0 & 67,5 & 71,2 & 53,7 & 53,7 & \multirow{6}{*}{$\begin{array}{l}\text { Ruído de trânsito } \\
\text { Ruído de trânsito } \\
\text { Ruído de trânsito }\end{array}$} \\
\hline & \#2 & 2,0 & 72,7 & 74,6 & 60,8 & $\mathrm{~N} / \mathrm{A}$ & \\
\hline & \#3 & 2,0 & 68,6 & 72,5 & 61,0 & $\mathrm{~N} / \mathrm{A}$ & \\
\hline & \#4 & 2,0 & 71,3 & 74,7 & 63,9 & $\mathrm{~N} / \mathrm{A}$ & \\
\hline & \#5 & 14,0 & 68,4 & 71,5 & 52,2 & 52,2 & \\
\hline & \#6 & 14,0 & 64,9 & 69,1 & 51,7 & 51,7 & \\
\hline \multirow{6}{*}{$\begin{array}{l}\text { Major Vaz } \\
\text { (Dia) }\end{array}$} & $\# 1$ & 2,0 & 60,7 & 62,7 & 44,3 & 44,3 & \\
\hline & \#2 & 19,5 & 51,4 & 54,6 & 42,6 & 42,6 & \\
\hline & \#3 & 21,0 & 53,7 & 58,4 & 44,0 & 44,0 & \\
\hline & $\# 4$ & 12,9 & 56,7 & 59,3 & 43,1 & 43,1 & \\
\hline & \#5 & 10,3 & 55,7 & 56,9 & 42,3 & 42,3 & \\
\hline & \#6 & 2,0 & 50,6 & 53,2 & 42,7 & 42,7 & \\
\hline \multirow{4}{*}{$\begin{array}{c}\text { Vila de Cava } \\
\text { (Dia) }\end{array}$} & $\# 1$ & 9,1 & 46,0 & 47,3 & 44,5 & 44,5 & \multirow{4}{*}{ Barulho de fundo } \\
\hline & \#2 & 2,1 & 53,8 & 54,5 & 52,8 & $\mathrm{~N} / \mathrm{A}$ & \\
\hline & \#3 & 7,4 & 57,1 & 56,0 & 42,0 & 42,0 & \\
\hline & \#4 & 7,2 & 55,9 & 59,4 & 45,5 & 45,5 & \\
\hline & $\# 1$ & 3,0 & 58,3 & 60,6 & 54,1 & 54,1 & \\
\hline Mackenzie & \#2 & 12,5 & 56,5 & 57,2 & 53,8 & 53,8 & \\
\hline (Dia) & \#3 & 13,5 & 59,9 & 62,3 & 55,2 & $\mathrm{~N} / \mathrm{A}$ & Barulho de fundo \\
\hline & \#4 & 31,4 & 59,8 & 58,3 & 54,5 & $\mathrm{~N} / \mathrm{A}$ & Barulho de fundo \\
\hline & $\# 1$ & 15,2 & 69,5 & 71,7 & 54,7 & 54,7 & \\
\hline Antônio (dia) & \#2 & 36,3 & 70,9 & 73,3 & 58,9 & 58,9 & \\
\hline Antonio (dia) & \#3 & 7,0 & 54,2 & 55,8 & 52,0 & 52,0 & \\
\hline
\end{tabular}

Nota: Incerteza expandida de $0,9 \mathrm{~dB}$ (associada à medição do descritor $\mathrm{L}_{95}$, conforme declarado no certificado de calibração do sonômetro CESVA SC420). 
Na Tabela 9, os descritores do nível de pressão sonora $\mathrm{L}_{\text {Aeq }}$, $\mathrm{L}_{10}$ e $\mathrm{L}_{95}$ foram definidos no capítulo 2, enquanto a coluna "Pontos de medição" caracteriza os diferentes pontos de medição onde a pressão sonora foi efetivamente medida, sempre incluindo, pelo menos, o ponto em frente ao portão principal de acesso à subestação e o ponto associado ao valor máximo da pressão sonora percebida pelo sonômetro nas proximidades da subestação. O sonômetro mede o descritor L95 conforme descrito anteriormente, e este descritor é a base para definição do descritor de interesse legal LR. Contudo, se o profissional habilitado responsável pela medição identificar a presença de ruídos externos, como tráfego de veículos, aparelhos de ar-condicionado, pessoas falando, etc., que possam ter atrapalhado a captação do ruído específico de interesse da medição (no caso em tela, o ruído acústico gerado pela subestação), o descritor L95 não pode ser utilizado, não sendo possível atribuir um valor para o descritor $L_{R}$, que recebe então a indicação "N/A" na última coluna, "Comentários". Esta coluna especifica, ainda, se algum componente tonal foi identificado, e nesses casos, o descritor $L_{R}$ já reflete o valor penalizado pela característica tonal do ruído em $+5 \mathrm{~dB}$.

Conforme reportado na Tabela 9, a subestação do Leme (foco do projeto de P\&D em desenvolvimento) já atende aos limites da legislação ambiental, principalmente devido a duas ações já implementadas: (i) manutenção corretiva dos sistemas auxiliares de ventilação e substituição dos interruptores magnéticos de alta tensão dos transformadores auxiliares de serviço; e (ii) eliminação da componente tonal do ruído (que incorreria na penalidade de $\mathrm{K}_{\mathrm{T}}$ ), por meio da instalação de um sistema de mascaramento desenvolvido em outro trabalho [4]. O único ponto que ultrapassa os limites regulamentados (Leme, PMed 1: 51,1 dB) está localizado bem em frente ao portão de aço de acesso à subestação, na divisa com a rua, portanto longe da área de influência de qualquer morador e sem quaisquer implicações legais. Uma ação mais efetiva visando à atenuação acústica do nível de pressão sonora no entorno da subestação Leme deverá ser alcançada em breve com a instalação de barreiras acústicas, cuja eficácia já foi comprovada por testes de laboratório.

Dois outros pontos de atenção recaem sobre as subestações Major Vaz (subestação de transição, sem transformadores, mas operando em zona de alta população) e Vila de Cava (a única subestação localizada em área afastada da área urbana, com baixa população). Conforme documentado, para essas subestações Major Vaz e Vila de Cava, todos os valores medidos de ruído acústico estão abaixo de 45,5 dB, de acordo com os limites da legislação (Tabela 4).

Na década de 1980, por iniciativa do governo municipal, foi elaborado um plano de expansão dos serviços de eletricidade na cidade do Rio de Janeiro, plano de obras da Light, o programa incluía a reconstrução de antigas linhas e instalação de outras vinculadas à operação de subestações em áreas densamente urbanizadas, onde seria impossível o atendimento por linhas aéreas [60]. Ao longo da década, cresceu o número de subestações inauguradas na cidade, contribuindo para o aumento da infraestrutura de serviços da cidade. Em 1982, foi inaugurada a Subestação Terminal Sul, no Jardim Botânico, garantindo o suprimento de energia 
elétrica aos bairros da zona sul da cidade do Rio de Janeiro. Em 1985, foram inauguradas as subestações São Conrado, para atender demanda reprimida de eletricidade da comunidade da Rocinha e parte da Barra da Tijuca (considerada a mais moderna do Sistema Light) e a de Botafogo, atendendo demandas localizadas nos bairros de Botafogo, Praia Vermelha e Urca. Ainda no mesmo ano foi inaugurada a subestação Mackenzie, suprindo a região central (portuária) nas áreas da Praça Mauá e regiões da vizinhança da avenida Rio Branco, Gamboa e Santo Cristo. A área central da cidade foi novamente contemplada após dois anos, com o início da construção da subestação Santa Luzia. Em 1988, entrou em operação a subestação Camerino, vizinha ao lote da subestação Mackenzie. Em 1989, a subestação Santo Antônio fortaleceu a capacidade instalada da Light. Destas, com exceção da subestação Terminal Sul, São Conrado (limítrofe à Rocinha) e Mackenzie, todas as subestações encontram-se instaladas em zonas habitadas, com lote ocupada por um conjunto de edifícios invólucro que esconde o equipamento na paisagem urbana [60].

A atual política da Light de planejamento de suas subestações elétricas prioriza o remanejamento logístico da rede, pela desativação, ampliação ou modernização dos equipamentos existentes. Embora não tenha sido identificado um inventário das subestações no Rio de Janeiro e de suas transformações ao longo dos anos, sabe-se que as modificações mais recentes incluem a desativação da subestação da Rua Larga, seguida da ampliação da subestação Camerino. Ainda assim, face às transformações pelas quais a cidade vem passando, novas subestações foram inauguradas. Em resposta aos grandes eventos como a Copa de 2014 e as Olimpíadas de 2016, foram projetadas as subestações Barra II (Parque Olímpico, projetada em parceria com Furnas), Gardênia Azul, Realengo e Thomaz Coelho e ampliação da subestação do Leme.

Em Niterói não foram obtidos dados oficiais quanto ao ano de inauguração de suas subestações. Contudo com base no cruzamento de informações concluiu-se que a subestação do Ingá é a mais recente e São Lourenço, a mais antiga. A subestação do Ingá apresenta outras condições, seus fechamentos ${ }^{5}$ são mais permeáveis e as alturas dos pórticos mais baixas [63]. Técnicos da Empresa de Pesquisas Energéticas (EPE) e da distribuidora Enel realizaram visita de campo para avaliar dois terrenos e indicar o mais adequado à construção da SE Ingá [61]. Mesmo encontrando-se em uma região com predominância de alta densidade, esta possui uma menor interferência, pois localiza-se numa via fechada e de fluxo de pessoas reduzido.

Por força do Decreto $n^{\circ}$ 62.313, de 23 de fevereiro de 1968, a Companhia Brasileira de Energia Elétrica ficou responsável (i) pela construção da linha de transmissão entre a nova subestação de Alcântara (no município de São Gonçalo) e a futura subestação na Zona Sul (no município de Niterói); (ii) pela a linha de transmissão entre a futura subestação da Zona Sul e a subestação de São Lourenço e (iii) pela construção da nova subestação na Zona Sul, município de Niterói, Estado

\footnotetext{
${ }^{5}$ Esta categoria está relacionada ao modo como o design pode afetar as escolhas dos usuários.
} 
do Rio de Janeiro, destinadas a interligar as subestações Alcântara, Zona Sul e São Lourenço. Foram declarados de utilidade pública para fins de desapropriação, as áreas de terra situadas na faixa de 30 metros de largura, tendo por eixo a linha de transmissão a ser estabelecida entre a nova subestação de Alcântara, município de São Gonçalo e a futura subestação na Zona Sul município de Niterói; bem como as situadas na faixa destinada à linha de transmissão entre a futura subestação na Zona Sul e a subestação de São Lourenço, ambas no município de Niterói [62].

O Apêndice A ilustra a evolução temporal do descritor LA de todos os pontos medidos das dez subestações presentes na pesquisa em períodos de 5 min, durante todo o monitoramento de longa duração.

\section{4 \\ Discussão dos resultados}

Os resultados das medições realizadas nas proximidades das dez subestações de alta tensão investigadas mostraram que, embora adequados aos níveis impostos pela legislação ambiental aplicável, na quase totalidade das subestações estudadas, os valores medidos se aproximam dos limites aceitáveis. Com base nos resultados obtidos é possível afirmar que os problemas vivenciados pela subestação Leme não refletem uma particularidade dessa subestação, mas sim uma realidade de outras subestações que também operam imersas em áreas urbanas com alta densidade populacional.

Se, por um lado, pode-se dizer que a legislação ambiental é extremamente rígida, por outro deve-se ter em mente que os limites da legislação são definidos de forma a preservar os riscos e ameaças à saúde humana do observador exposto ao ruído acústico. Isso certamente reflete um dilema ao se considerar que inúmeros equipamentos de uso pessoal e de conforto ambiental geram ruídos (ainda que momentâneos) que extrapolam os limites tolerados pela regulação aplicável, ou seja, $55 \mathrm{~dB}$ durante o período diurno e $50 \mathrm{~dB}$ durante o noturno, para a maioria das subestações investigadas (ver Tabela 7). Um aparelho residencial de ar condicionado (12.000 BTU) gera um ruído acústico da ordem de $64 \mathrm{~dB}$; secador de cabelo convencional de potência média (cerca de $1600 \mathrm{~W}$ ), gera ruído de $85 \mathrm{~dB}$, apenas para ilustrar alguns exemplos. Enquanto o primeiro pode ser utilizado de forma contínua durante os dias de inverno, o segundo é utilizado apenas durante pequenos intervalos de tempo, mitigando o seu efeito à saúde, ainda que nocivo. Sem nenhum controle, transmissões de televisão drasticamente aumentam a amplitude do som durante seus comerciais e motocicletas e automóveis circulam livremente, gerando ruídos que também extrapolam os limites aceitáveis. Para mitigar o nível de pressão sonora em uma subestação elétrica, não se pode perder de vista que a própria subestação já está imersa no ambiente da cidade, que incorpora muitas outras fontes de ruído de intensidade não desprezível.

Para definir referências de comparação, medições da pressão sonora foram realizadas em três locais da cidade do Rio de Janeiro: (i) no bairro da Urca 
(considerado o mais silencioso, já que protegido pela barreira acústica natural imposta pelo maciço do Pão de Açúcar (L95 = 42,5); (ii), no ambiente aberto de Lagoa Rodrigo de Freitas, localizado na zona residencial sul do Rio de Janeiro (L95 $=\mathrm{dB} 45,3 \mathrm{~dB}$ ) e (iii), no topo do monumento do Cristo Redentor, a $704 \mathrm{~m}$ de altitude no Morro do Corcovado ( $\mathrm{L} 95=58,1 \mathrm{~dB}$ ). Isso para dizer que o barulho natural que emana da cidade já coloca sob suspeita os limites impostos pela rígida legislação ambiental.

Conforme recentemente demonstrado pelos resultados de um projeto de P\&D em fase final de desenvolvimento (Light/Aneel 00382-0128/2019, desenvolvido por pesquisadores do PósMQI/PUC-Rio), dentro de certos limites, é possível não apenas reduzir a importunação que o ruído acústico causa no ouvido humano como mitigar a sua intensidade. O primeiro pode ser aliviado pelo uso da técnica de mascaramento acústico (superposição de sons da natureza ao ruído de fundo, que permite eliminar a característica tonal do ruído responsável pelo incômodo, e que, também, evita a penalização de $+5 \mathrm{~dB}$ nos valores medidos da pressão sonora). Já a intensidade da pressão sonora pode ser mitigada pelo uso de barreiras acústicas, que blindam a fonte sonora emissora. Conforme demonstrado pelo referido projeto de $\mathrm{P} \& \mathrm{D}$, embora seja possível atenuar os efeitos do ruído acústico percebido no entorno de subestações de energia elétrica, eliminá-los por completo é impossível, já que o ruído gerado por qualquer transformador de alta tensão resulta de um fenômeno físico (magnetostricção) que é inerente ao seu próprio funcionamento. Assim, dentro de restrições que são inerentes às fontes de ruído, é importante ter em mente que pequenas são as margens de manobra para se adequar o nível da pressão sonora aos rígidos limites da regulação ambiental. 


\section{5 \\ Conclusões e trabalhos futuros}

Além do esforço que se faz necessário para reduzir o ruído acústico gerado pela operação de subestações de alta tensão, é necessário refletir sobre a necessidade de um planejamento urbano para regular ou prevenir a construção de edifícios residenciais em áreas de risco nas proximidades de subestações já em operação. Também se faz necessário estimular e fomentar pesquisas e o aprimoramento de tecnologias, a exemplo dos desenvolvimentos recentes de materiais ativos capazes de exibir alto coeficiente magnetoelástico com características estáveis em uma ampla faixa de temperaturas [58]. Não obstante as limitações impostas pelo fenômeno da magnetostrição e que são intrínsecas ao funcionamento de transformadores [57] de alta tensão elétrica, o setor clama por tecnologias inovadoras voltadas para a construção de transformadores mais silenciosos.

Em sintonia aos objetivos originalmente formulados por esta pesquisa de mestrado, três são as conclusões do trabalho, a seguir caracterizados.

- No que concerne ao primeiro objetivo (normas e leis aplicáveis), o trabalho identificou e analisou o amplo acervo de normas técnicas associadas à medição e caracterização de ruído acústico e suas restrições, assim orientando a realização de um plano estruturado de medições e mapeamento da pressão acústica, que orientou o estudo em diferentes subestações em operação no Estado do Rio de Janeiro;

- No que concerne o segundo objetivo específico (caracterização do nível do ruído acústico no entorno de subestações de energia elétrica), o trabalho monitorou e avaliou o nível da pressão sonora na vizinhança de dez subestações de energia elétrica em operação em áreas metropolitanas de alta densidade populacional, localizadas em regiões submetidas a diferentes legislações ambientais, localizadas em duas áreas de concessão gerenciadas por duas concessionárias de energia.

- Já no que concerne ao terceiro objetivo específico (conformidade do nível da pressão sonora em subestações de energia à legislação ambiental aplicável), os resultados das medições de monitoramento da pressão sonora comprovaram que, dentro da confiabilidade metrológica das medições realizadas, de uma forma geral, o nível da pressão sonora no entorno de todas as dez subestações estudadas encontram-se em conformidade aos limites impostos pela legislação ambiental aplicável, porém beirando os limites máximos.

Não obstante o rigor da legislação ambiental aplicável — que sem dúvida precisa ser rigorosa, já que a exposição de longo prazo ao ruído acústico pode 
comprometer a saúde humana - adequar-se aos rígidos limites da legislação ambiental aplicável não constitui tarefa trivial, requer soluções tecnológicas e expertise para a sua aplicação.

Dentre as sugestões de desdobramentos do trabalho, recomenda-se não apenas ampliar o estudo para envolver um maior número de subestações, mas, também, conseguir a autorização e o envolvimento da concessionária para que as fontes sonoras possam ser adequadamente caracterizadas e medições realizadas no ambiente interno da subestação. Resultados de um estudo mais amplo de um programa estruturado de medições do ruído acústico nos ambientes interno e externo de subestações de energia certamente poderão contribuir não apenas para a adoção de planos mais ousados de manutenção de subestações de energia quanto para o aprimoramento da legislação ambiental, adequando-a à realidade das subestações. 


\section{Referências bibliográficas}

[1] SAES, Alexandre Macchione. Luz, leis e livre-concorrência: conflitos em torno das concessões de energia elétrica na cidade de São Paulo no início do século XX. História (São Paulo), v. 28, n. 2, p. 173-234, 2009.

[2] Sally L. Lusk, Bonnie M. Hagerty, Brenda Gillespie. Chronic Effects of Workplace Noise on Blood Pressure and Heart Rate. Center for Statistical Consultation and Research, University of Michigan, Ann Arbor, Michigan \&Claire C. Caruso. Pages 273-281. Published online: 05 Apr 2010. Download citation https://doi.org/10.1080/00039890209601410.

[3] PIANA, E. A.; ROOZEN, N. B. On the Control of Low-Frequency Audible Noise from Electrical Substations: A Case Study. Applied Sciences, v. 10, n. 2, p. 637, 16 jan. 2020.

[4] FROTA, M. N.; REGAZZI, R. D.; CUNHA, B.; MIRANDA, H. V.; HALL. C. R.; ALVARENGA, J.; BRAGANTINE, S.; Vigilância do nível de pressão sonora: PUC-Rio, 2019, 45p. Relatório Técnico do P\&D Light/Aneel 003820128/2019 ("Controle de níveis de pressão sonora em subestação de energia.

[5] BARRON, R. F. Industrial Noise Control and Acoustics. 1. ed. [s.1.] CRC Press, 2002.

[6] Lei Ordinária (Rio de Janeiro), No 3.268, de 29 de agosto de 2001 (Altera o regulamento $\mathrm{n}^{\mathrm{o}} 15$, aprovado pelo Decreto n. ${ }^{\circ} 1.601$, de 21 de junho de 1978, e alterado pelo Decreto ${ }^{\circ} 5.412$, de 24 de outubro de 1985).

[7] ASSOCIAÇÃO BRASILEIRA DE NORMAS TÉCNICAS (ABNT ). NBR 10.151: Acústica - Avaliação do ruído em áreas habitadas, visando o conforto da comunidade - Procedimento. Rio de Janeiro, 2000.

[8] LAZZARINI, Victor EP. Elementos de acústica. apostila do Departamento de Artes da UEL, Londrina, 1998.

[9] BISTAFA, Sylvio R. Acústica aplicada ao controle do ruído. Editora Blucher, 2018.

[10] KNOBEL, Marcelo. Física da Fala e da Audição. Ifi-Instituto De Física Unicamp. [Online] [Citado Em: 2010 De 07 De 02.] Http://Www. Ifi. Unicamp. $\mathrm{Br} / \sim$ Knobel F, v. 105.

[11] ISBERT, Antoni Carrión. Diseño acústico de espacios arquitectónicos. Univ. Politèc. de Catalunya, 1998.

[12] C.L. Dolph, A current distribution of broadside arrays which optimizes the relationship between beam width and sidelobe level, Inst. Radio Eng. 34 (1946) 335-348.

[13] R. Harrington, Sidelobe reduction by non-uniform element spacing, Inst. Radio Eng. Trans. Antennas Propag. 9 (1961) 187-201.

[14] T.T. Taylor, Design of line source antennas for narrow beam width and low sidelobes, IRE Trans. Antennas Propag. AP-3 (1955) 16-28.

[15] J. Capon, High-resolution frequency-wavenumber spectrum analysis, Proc. IEEE 57 (8) (1969) 1408-1418, https://doi.org/10.1109/proc.1969.7278.

[16] J. Billingsley, The acoustic telescope, J. Sound Vib. 48 (48) (1974) 485-510, 
https://doi.org/10.1016/0022-460X(76)90552-6.

[17] M.J. Fisher, M. Harper-Bourne, S.A.L. Glegg, Jet engine noise source location: the polar correlation technique, J. Sound Vib. 51 (1) (1977) 23-54.

[18] J. Billingsley, A comparison of the source location techniques of the acoustic telescope and polar correlation, J. Sound Vib. 61 (3) (1978) 419-425. https://doi.org/10.1016/0022-460X(78)90389-9.

[19] Chiariotti P. Martarelli M. and Castellini P. Acoustic beamforming for noise source localization - Reviews, methodology and applications. Mechanical Systems and Signal Processing, Elsevier Journal. Vol. 120, 1 April 2019, pp. 422-448. https://doi.org/10.1016/j.ymssp.2018.09.019.

[20] GERGES, S. N. Y. Ruído: fundamentos e controle. 2. ed. Florianópolis: NR Editora, 2000. 676p.

[21] BRÜEL \& KJÆR. Environmental noise. Denmark: Brüel \& Kjær Sound \& Vibration Measurement A/S, 2000. 65p.

[22] ISO 9613-2: 1996 Acústica - Atenuação do som durante a propagação ao ar livre - Parte 2: Método geral de cálculo

[23] ISO 1996-1: 1982 Acústica - Descrição e medição de ruído ambiental - Parte 1: Quantidades e procedimentos básicos

[24] ISO 1996-1: 2016 Acústica - Descrição, avaliação e medição do ruído ambiental

[25] ISO 15667: 2000 (en) Acústica - Diretrizes para controle de ruído em gabinetes e cabines

[26] IEC 61094:2016, Electroacoustics - Measurement microphones - Part 5: Methods for pressure calibration of working standard microphones by comparison

[27] IEC 61260:1995, Electroacoustics - Octave-band and fractional octave-band filters

[28] IEC 61672-1:2013, Electroacoustics - Sound level meters - Part 1: Specifications

[29] ISO 140-10, Acústica - Medição de isolamento acústico em edifícios e de elementos de construção - Parte 10: Medições laboratoriais de isolamento acústico aerotransportado de pequenos elementos de construção.

[30] Plano Urbanístico da Região das Praias da Baía - Lei 1967/2002. Niterói: Secretaria de Urbanismo e Controle Urbano, 2002 (mimeo)

[31] ASSOCIAÇÃO BRASILEIRA DE NORMAS TÉCNICAS (ABNT). NBR 10.152: Níveis de ruído para conforto acústico - Procedimento. Rio de Janeiro, 1987.

[32] ASSOCIAÇÃO BRASILEIRA DE NORMAS TÉCNICAS (ABNT). NBR 16.313: Acústica - Terminologia - Procedimento. Rio de Janeiro, 2014.

[33] ASSOCIAÇÃO BRASILEIRA DE NORMAS TÉCNICAS (ABNT). NBR 16.425: Acústica - Medição e avaliação de níveis de pressão sonora provenientes de sistemas de transportes Parte 1: Aspectos gerais - Procedimento. Rio de Janeiro, 2016.

[34] ASSOCIAÇÃO BRASILEIRA DE NORMAS TÉCNICAS (ABNT). NBR 17.025: Requisitos gerais para a competência de laboratórios de ensaio e calibração - Procedimento. Rio de Janeiro, 2017.

[35] ABNT NBR 15575-1:2013 Edificações habitacionais. Desempenho - Requisitos gerais. Disponível em: <http://www.abnt.org.br/.>. Acesso em: 10mar. 2020.

[36] BRASIL. Resolução CONAMA N¹, de 08 de março de 1990. Dispõe sobre 
critérios de padrões de emissão de ruídos decorrentes de quaisquer atividades industriais, comerciais, sociais ou recreativas, inclusive as de propaganda política. Publicado no D.O.U de 02 Abril 1990

[37] BRASIL. Resolução CONAMA N², de 08 de março de 1990. Institui em caráter nacional o Programa Nacional, Educação e Controle da Poluição Sonora - "SILENCIO". Publicado no D.O.U de 02 Abril 1990.

[38] ISO 14001: 2015 Sistemas de gestão ambiental — Requisitos com orientações para uso

[39] GERAIS, Disposições. Lei n ${ }^{\circ}$ 9.605, de 12 de fevereiro de 1998. Dispõe sobre as sanções penais e administrativas derivadas de condutas e atividades lesivas ao meio ambiente, e dá outras providências. O Presidente da República. Citado na, p. 23.

[40] ASSOCIAÇÃO BRASILEIRA DE NORMAS TÉCNICAS (ABNT). NBR 15928: Ensaio não destrutivo - Análise de vibrações - Terminologia Procedimento. Rio de Janeiro, 2011.

[41] NHO-01 R/E - 2001: Norma para Avaliação da Exposição ao Ruído.

[42] BRASIL. (2010). Lei n. 12.305 de 02 de agosto de 2010. Institui a Politica Nacional de Resíduos Sólidos; altera a lei n.9.605, de 12 de fevereiro de 1998; e dá outras providencias. Diário Oficial da República Federativa do Brasil, Poder Executivo, Brasília DF.

[43] São Paulo (Estado) (2002) Legislação que da nova redação à Lei n 997/76, aprovada pelo Decreto ${ }^{\circ} 8.468$ que dispõe sobre a prevenção e o controle da poluição do meio ambiente. Decreto $\mathrm{n}^{\circ} 47.397,2002$, p. 1-18.

[44] São Paulo. Câmara Municipal. Lei 11501, de 11/04/94: Controla a emissão de ruídos por estabelecimentos de diversão e outros. São Paulo, 1994a.

[45] CETESB. Norma Técnica 11.032/1992, Determinação do nível de ruído em ambientes internos e externos de áreas habitadas: método de ensaio. São Paulo, 1992.

[46] CETESB. Norma Técnica 11.033/1992, Processo prático para calcular o nível de ruído equivalente contínuo: procedimento. São Paulo, 1992.

[47] CETESB. Norma Técnica 11.033/1992. Define critérios de ruído para recintos internos e edificações: procedimento. São Paulo, 1992.

[48] DECISÃO DE DIRETORIA No 215/2007/E, de 07 de novembro de 2007.

[49] Câmara Municipal. Lei 11.986, de 16/01/96: Dispõe sobre o controle e a fiscalização das atividades que gerem poluição sonora, impõe penalidades, e dá outras providências. São Paulo, 1996.

[50] Câmara Municipal. Lei 11.780, de 30/06/95: Dispõe sobre as obrigações do Poder Público Municipal e dos proprietários ou incorporadores de edificações, no controle da poluição sonora no município de São Paulo, e dá outras providências. São Paulo, 1995.

[51] Câmara Municipal. Lei 11.804, de 19/06/95: Dispõe sobre avaliação da aceitabilidade de ruídos na Cidade de São Paulo, visando o conforto da comunidade. São Paulo, 1995.

[52] DECRETO No 35.928, DE 6 DE MARÇO DE 1996

[53] SMAC (RJ). Resolução No 198, de 22 de fevereiro de 2002. Dispõe sobre a padronização dos procedimentos de fiscalização da poluição sonora.

[54] PREFEITURA DO RIO DE JANEIRO. (Secretaria Municipal de Ordem Pública). Decreto n. 29.881, de 18 de setembro de 2008. Consolida as Posturas da Cidade do Rio de Janeiro e dá outras providências. Rio de Janeiro, RJ: 
Prefeitura da Cidade do Rio de Janeiro, 2008. Disponível em:

http://www.pcrj.rj.gov.br/web/seop/exibeconteudo?id=5811335. Acesso em: 29 jun. 2017.

[55] Câmara Municipal de Niterói. LEI 1967, de 04/04/2002: Dispõe sobre o plano urbanístico da região das praias da baía, seu zoneamento ambiental, a implementação de políticas setoriais, a aplicação de instrumentos de política urbana e a ordenação do uso e da ocupação do solo na região. Rio de Janeiro 2002.

[56] DE MELLO, Celso Antônio Bandeira. Natureza jurídica do zoneamentoefeitos. Revista de Direito Administrativo, v. 147, p. 23-38, 1982.

[57] J.G. Charles, The effect of the level of magnetostriction upon noise \& vibration of model single-phase transformer, Electrical Research Association (ERA), 1967.

[58] A.G. Olabi, A. Grunwald, "Design and application of magnetostrictive materials", 29 (2): 469-483.

[59] BIES, David A.; HANSEN, Colin H. Engineering noise control: theory and practice. CRC press, 2017.

[60] LINS, Miriam Victoria Fernandez. Impactos morfológicos gerados por equipamentos de infraestrutura urbana: um olhar sobre as subestações elétricas no Rio de Janeiro. 2015. Tese de Doutorado. Dissertação de Mestrado, PROURB FAU UFRJ, Rio de Janeiro.

[61] ALTERNATIVA, ANÁLISE TÉCNICO-ECONÔMICA DE. ESTUDOS PARA A LICITAÇÃO DA EXPANSÃO DA TRANSMISSÃO.

[62] DECRETO No 62.313, DE 23 DE FEVEREIRO DE 1968

[63] ALVES, Ana Beatriz Jardim. Subestações elétricas e suas configurações espaciais - Uma análise da área central e pericentral de Niterói. XVIII ENANPUR NATAL 2019, 27131 maio.

[64] https://pt.wikipedia.org/wiki/Amplitude

[65] Nível Físico - Modulação Digital, UNIVERSIDADE FEDERAL DO RIO GRANDE DO SUL https://www.inf.ufrgs.br/ roesler/disciplinas/Labredes/Lab1_NivelFisico/Lab1_ ModulacaoDigital.pdf

[66] https://www.ruidobaixafrequencia.pt/espetro-de-frequencia/

[67] https://pt.wikipedia.org/wiki/Ru\%C3\%ADdo 


\section{7}

\section{Apêndice A}

Este apêndice é composto pelos pontos de medição de todas as subestações que compõe a pesquisa.

Todos os dados aqui apresentados foram calculados a partir dos dados medidos em campo no escopo deste trabalho, de modo a auxiliar novos estudos sobre este mesmo tema. Estes dados presentes na Ttabela 9 e calculados para as subestações, que até então não se encontram na literatura, servirão de grande auxílio e suporte para novas pesquisas. A catalogação de tais dados age como forma de suporte e estímulo para outros trabalhos que possam utilizar tais dados para avaliação dos níveis de pressão sonora de outras subestações de energia do estado do Rio de Janeiro.

As Figuras 16, 17, 18, 19, 20, 21, 22 apresentam a caracterização temporal dos pontos das subestações de energia estudadas.
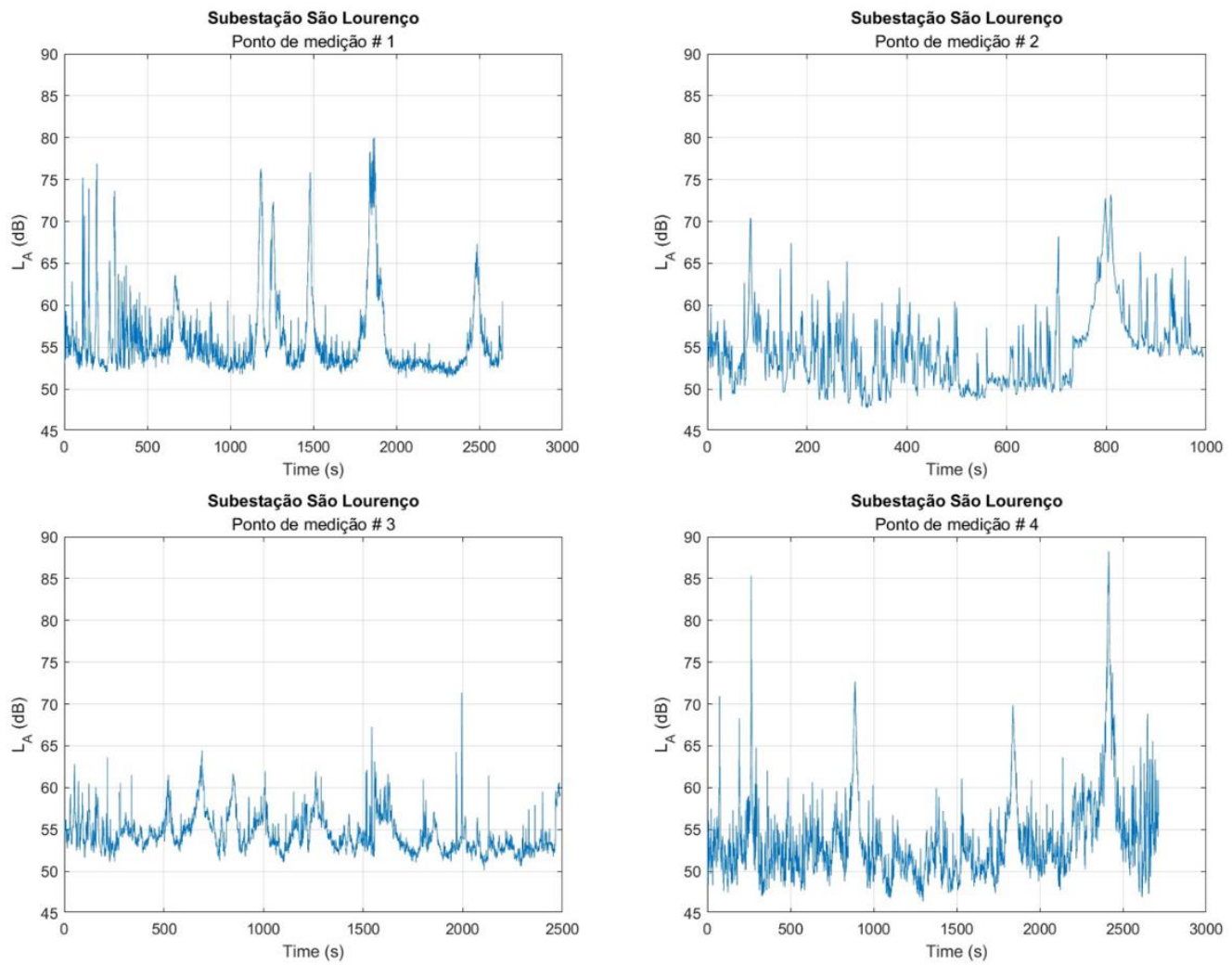

Figura 16: Níveis de pressão de ruído na subestação São Lourenço 

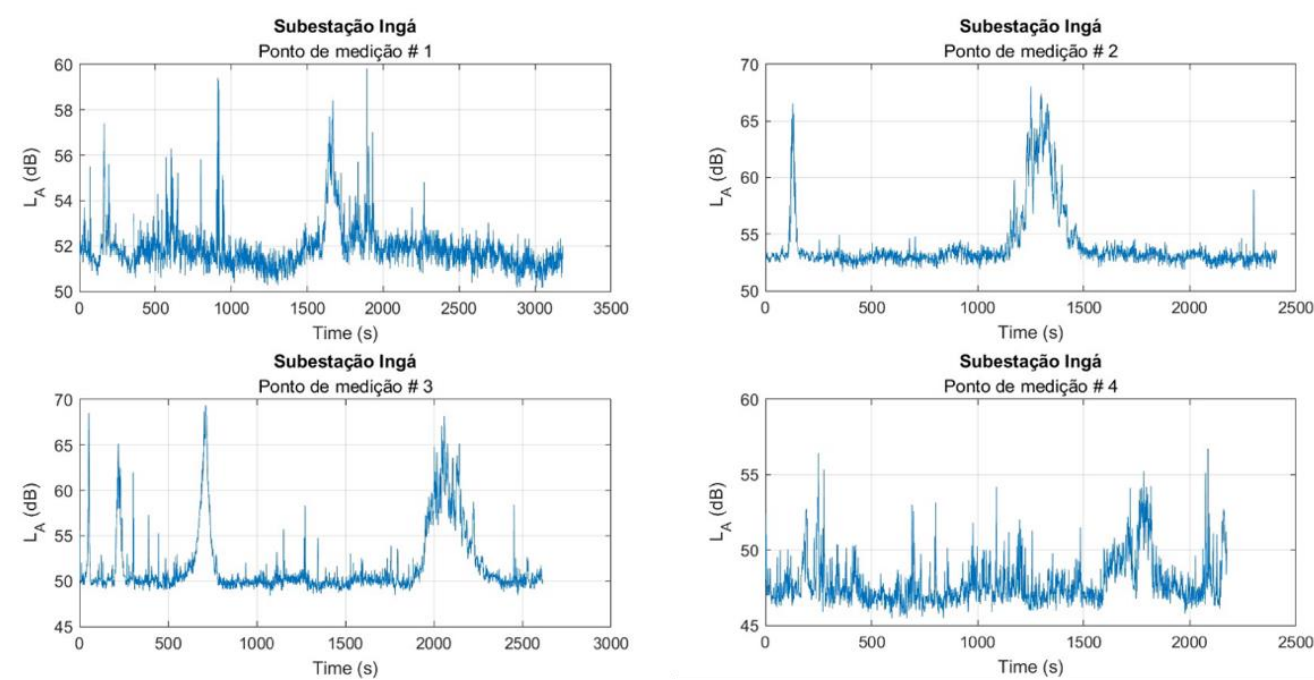

Figura 17: Níveis de pressão de ruído na subestação Ingá
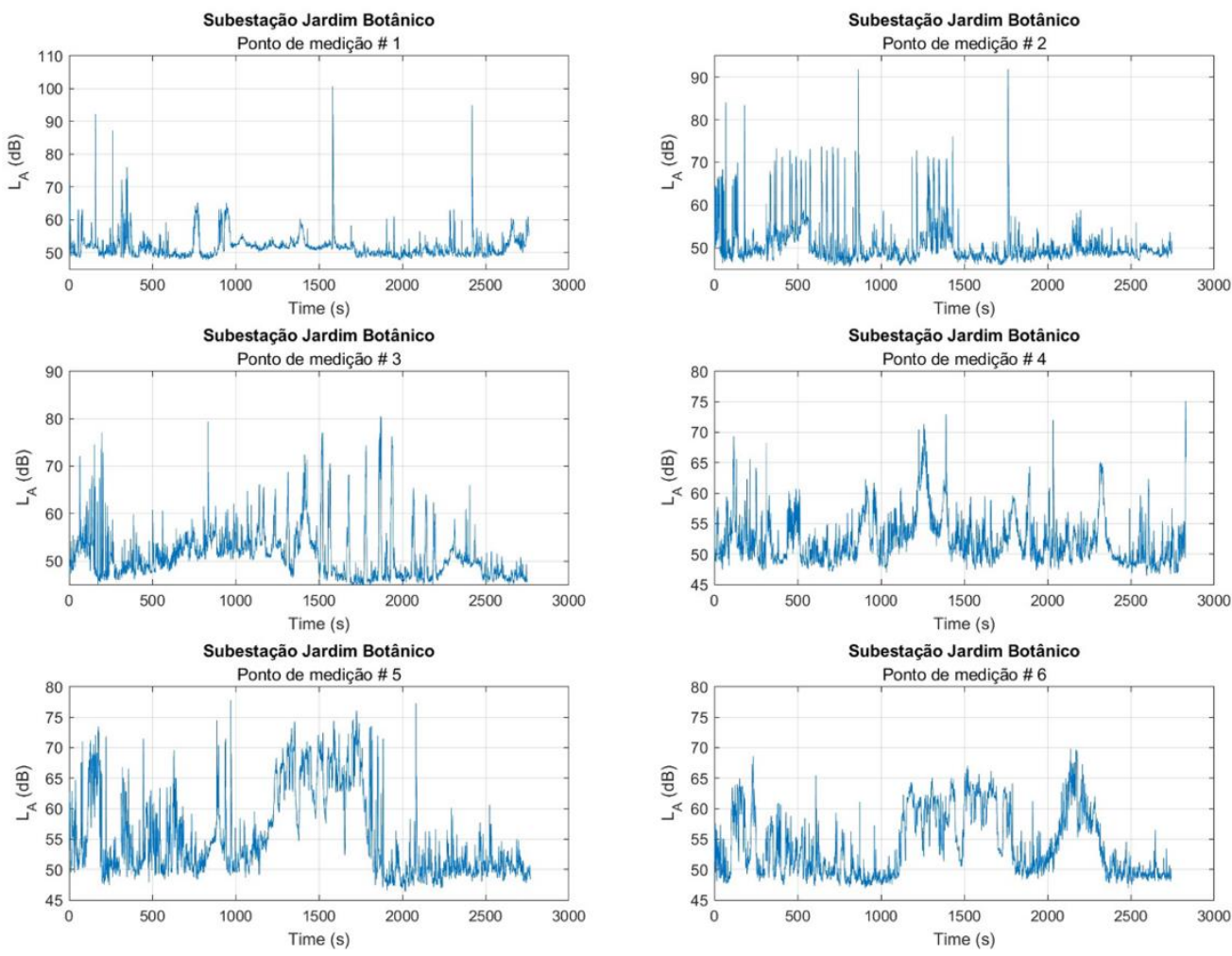

Figura 18: Níveis de pressão de ruído na subestação Jardim Botânico 

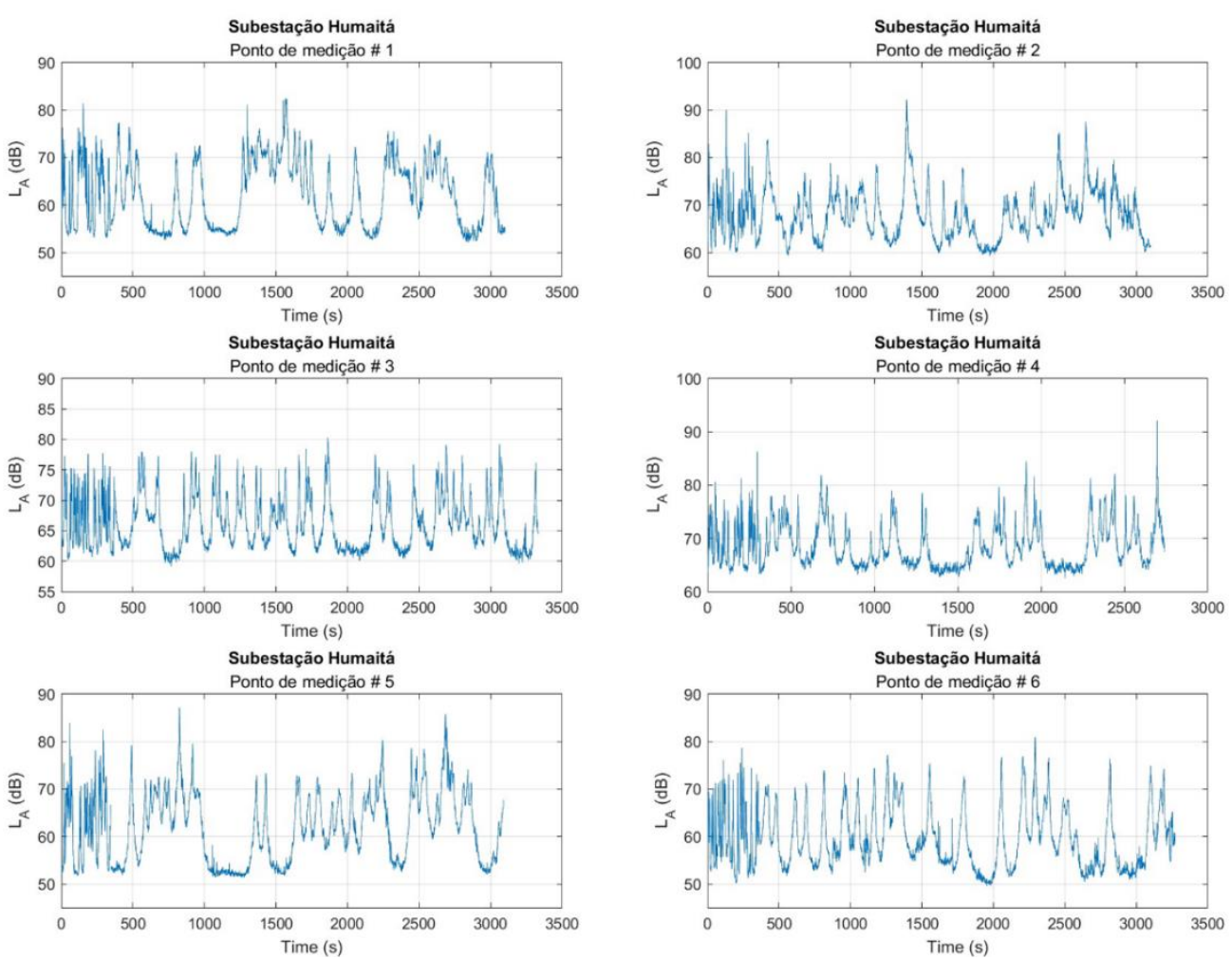

Figura 19: Níveis de pressão de ruído na subestação Humaitá
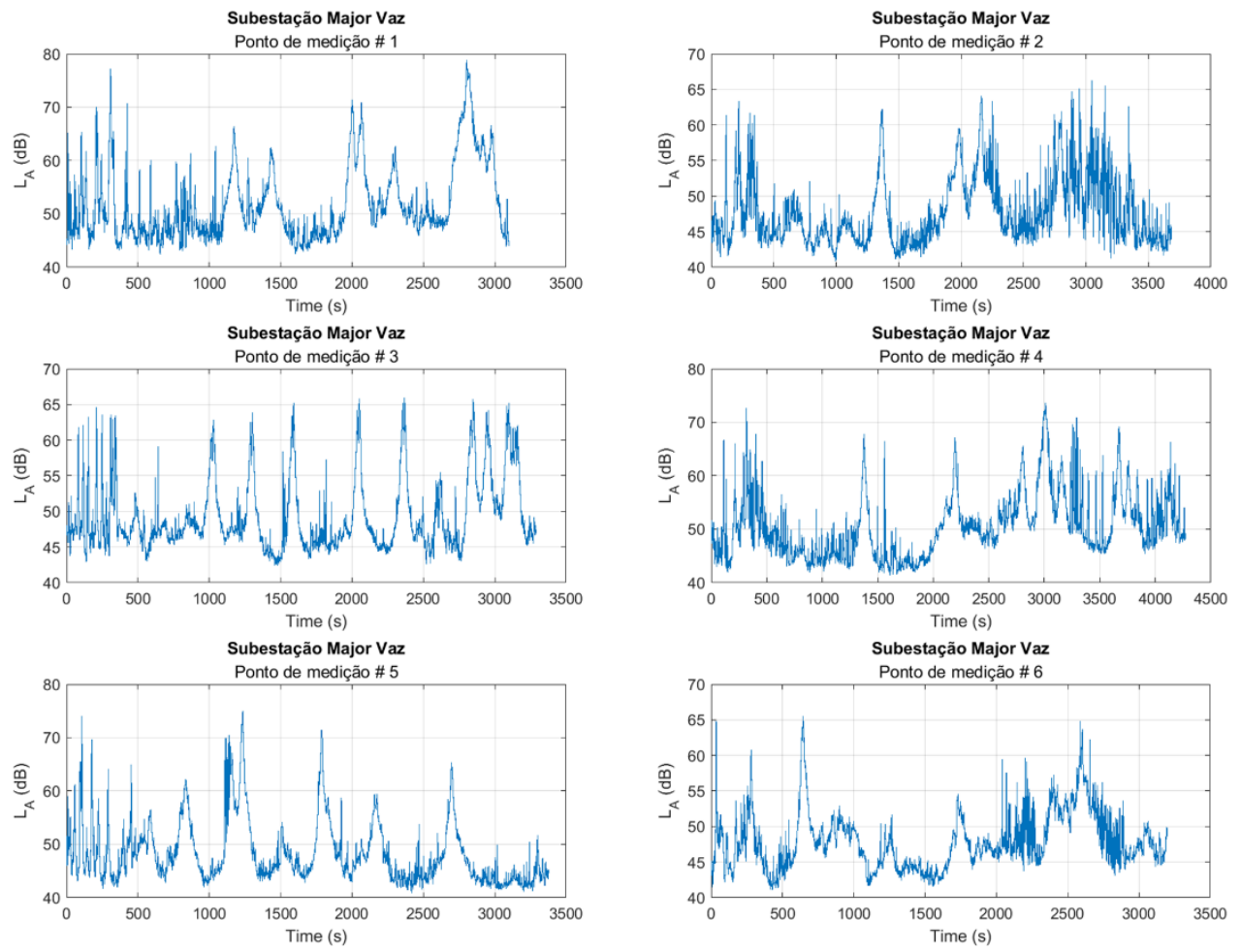

Figura 20: Níveis de pressão de ruído na subestação Major Vaz 

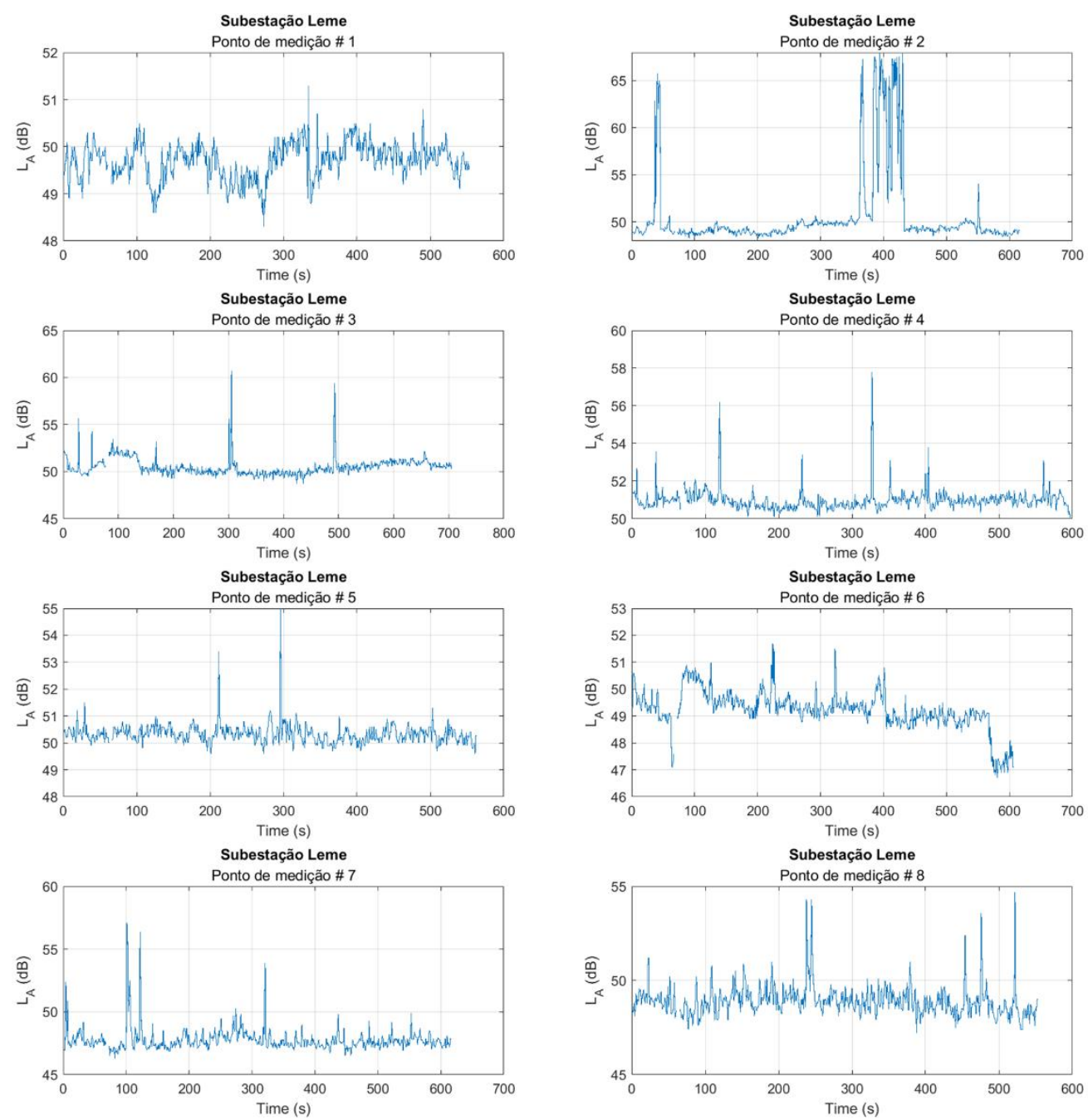

Figura 21: Níveis de pressão de ruído na subestação Leme 

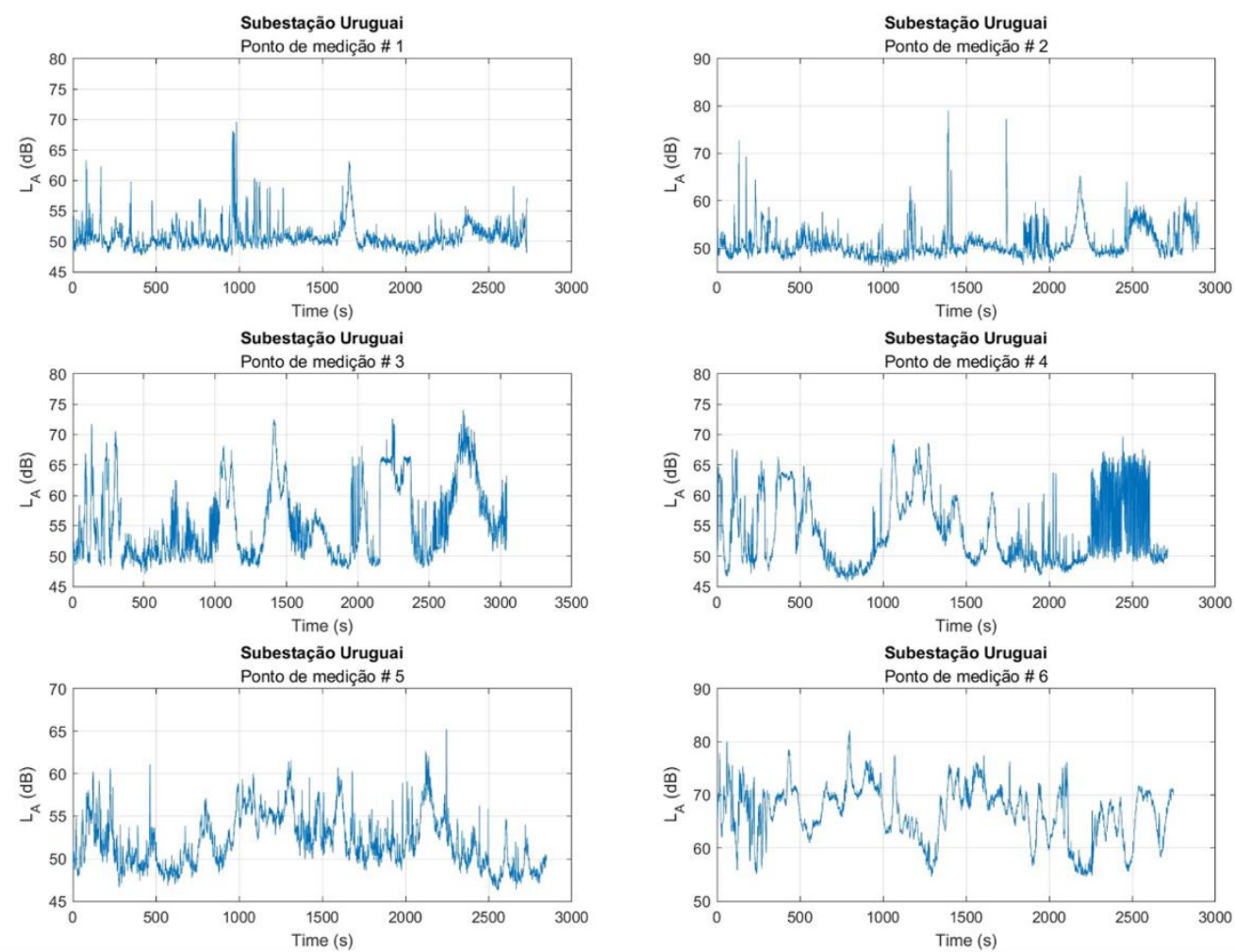

Ũ

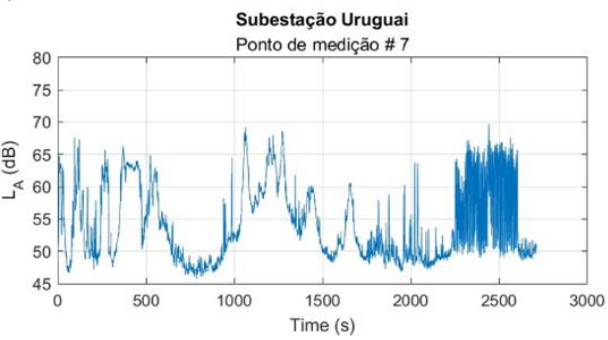

Figura 22: Níveis de pressão de ruído na subestação Uruguai 


\section{8 \\ Anexo A: Confiabilidade metrológica das medições de pressão sonora}

Este Anexo apresenta os certificados de calibração dos instrumentos de medição utilizados para realizar as medições da pressão sonora que fundamentaram o estudo do nível de ruído nas dez subestações elétricas estudadas.

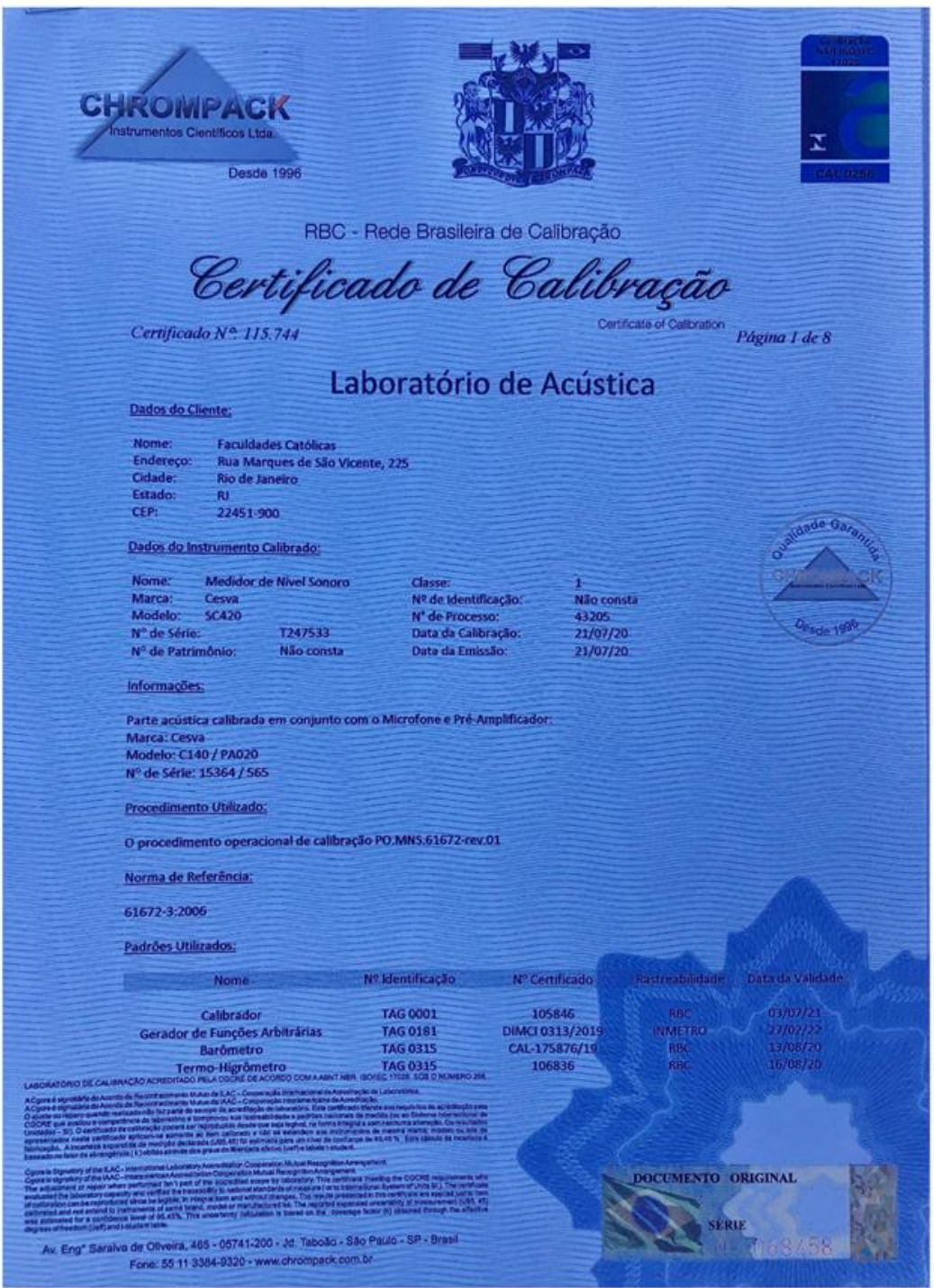




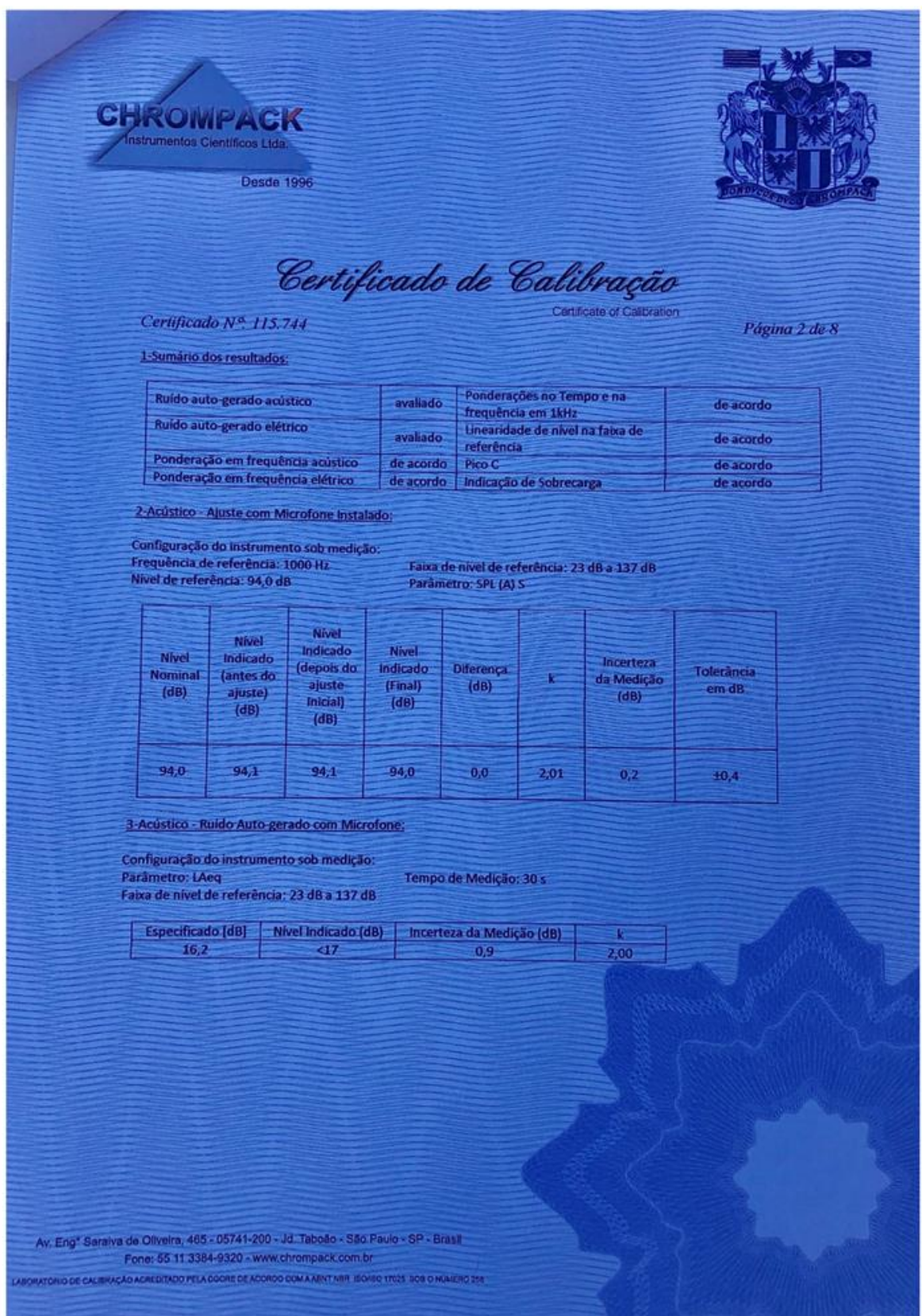




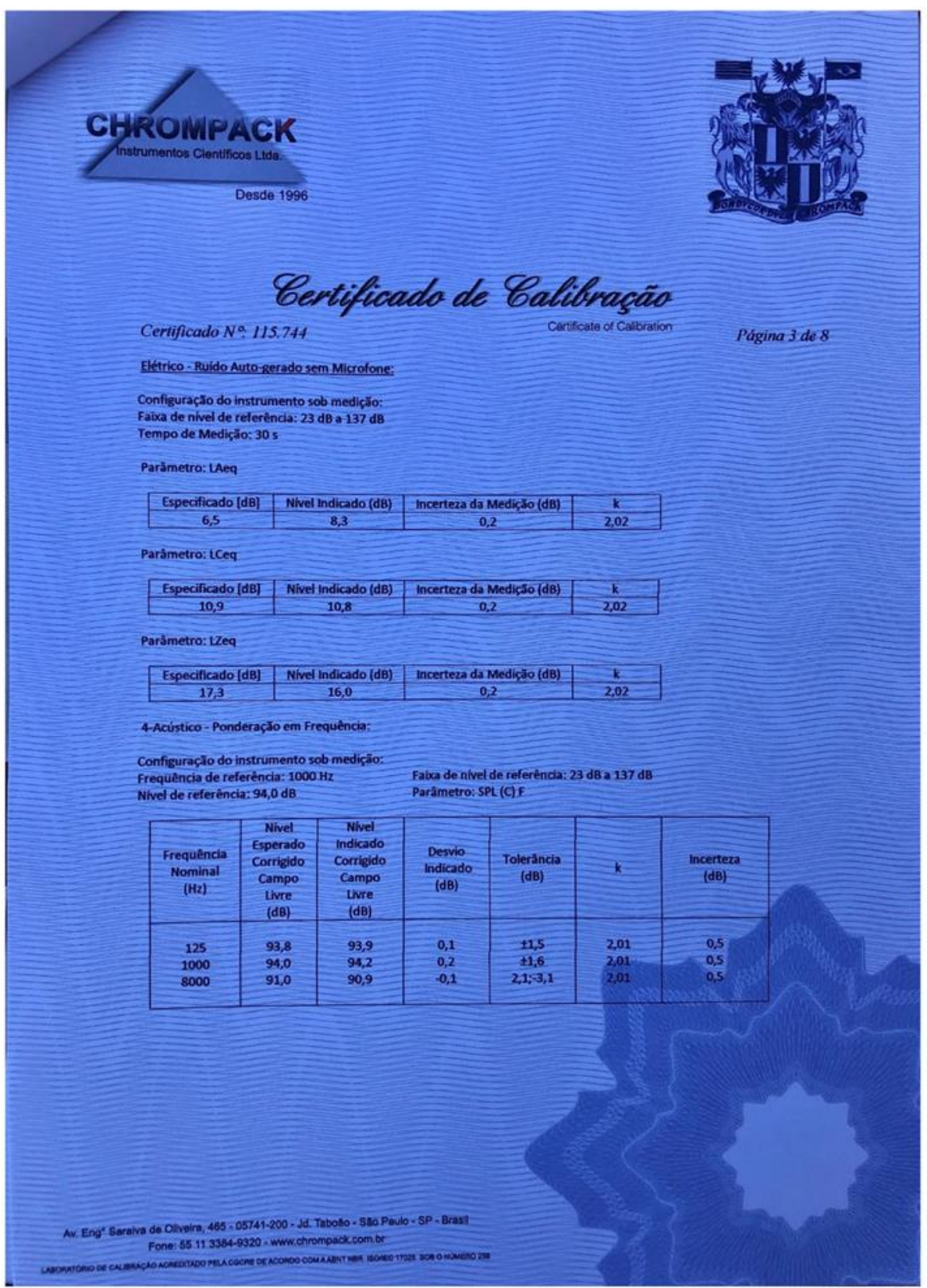




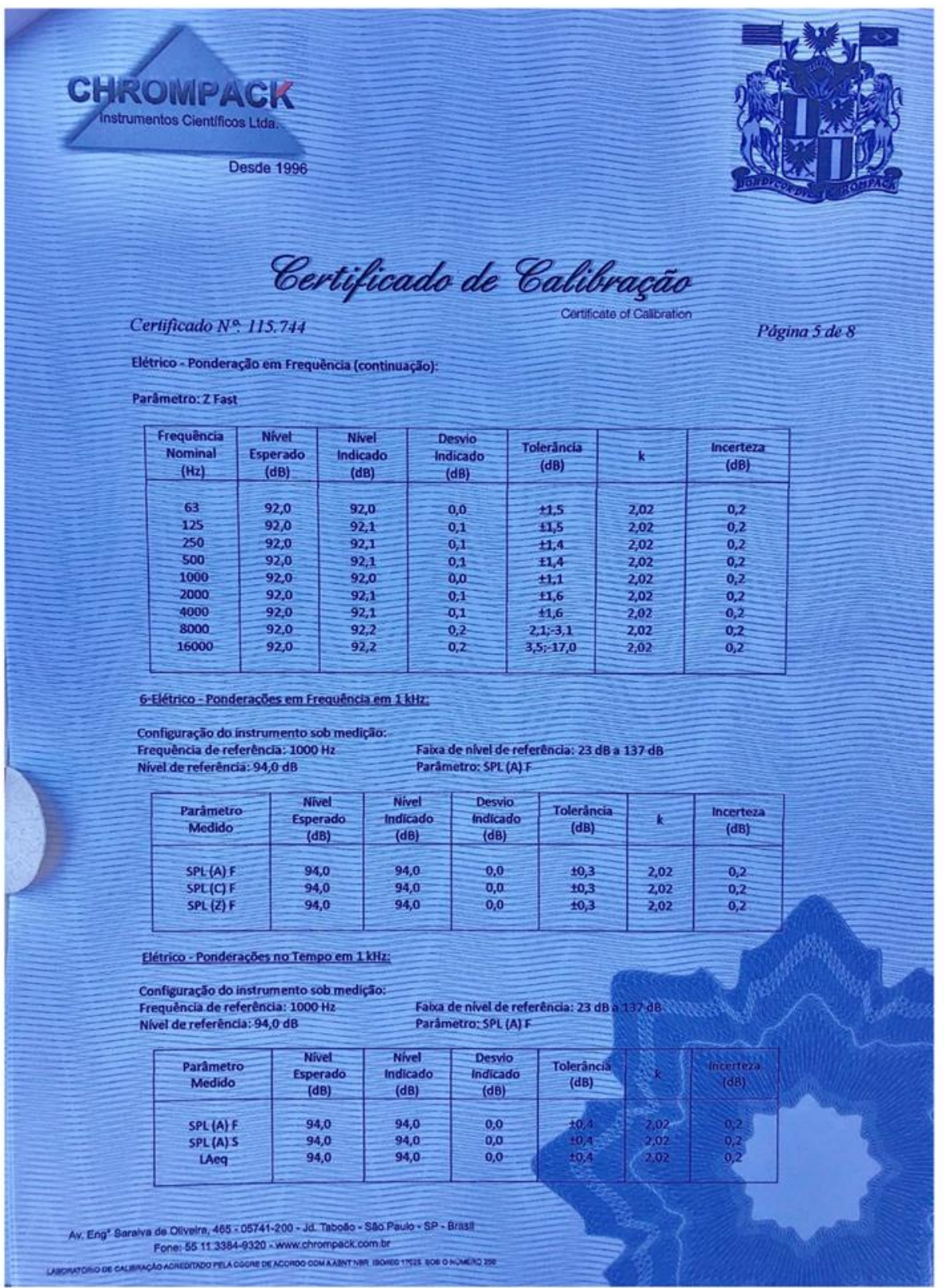




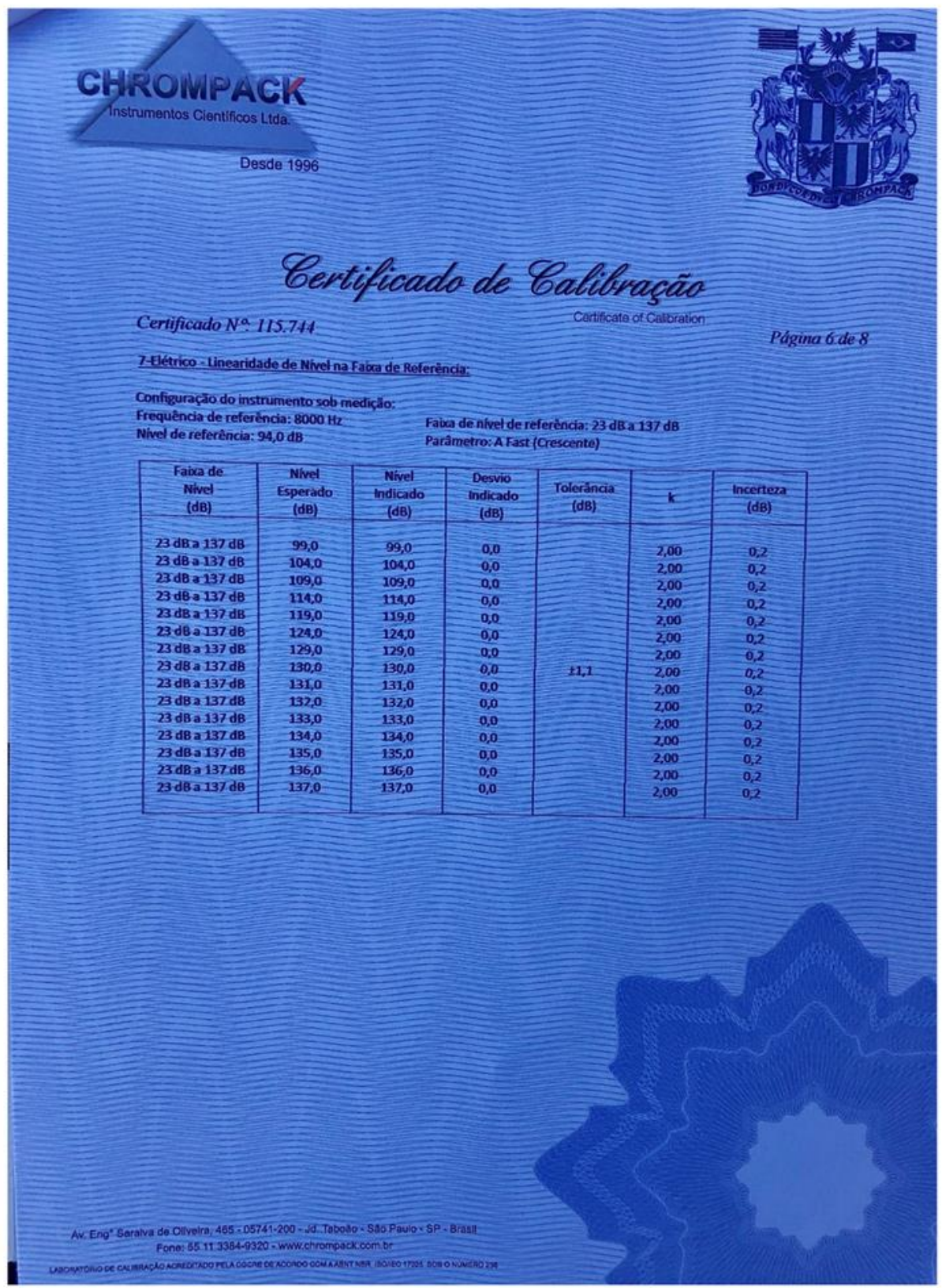




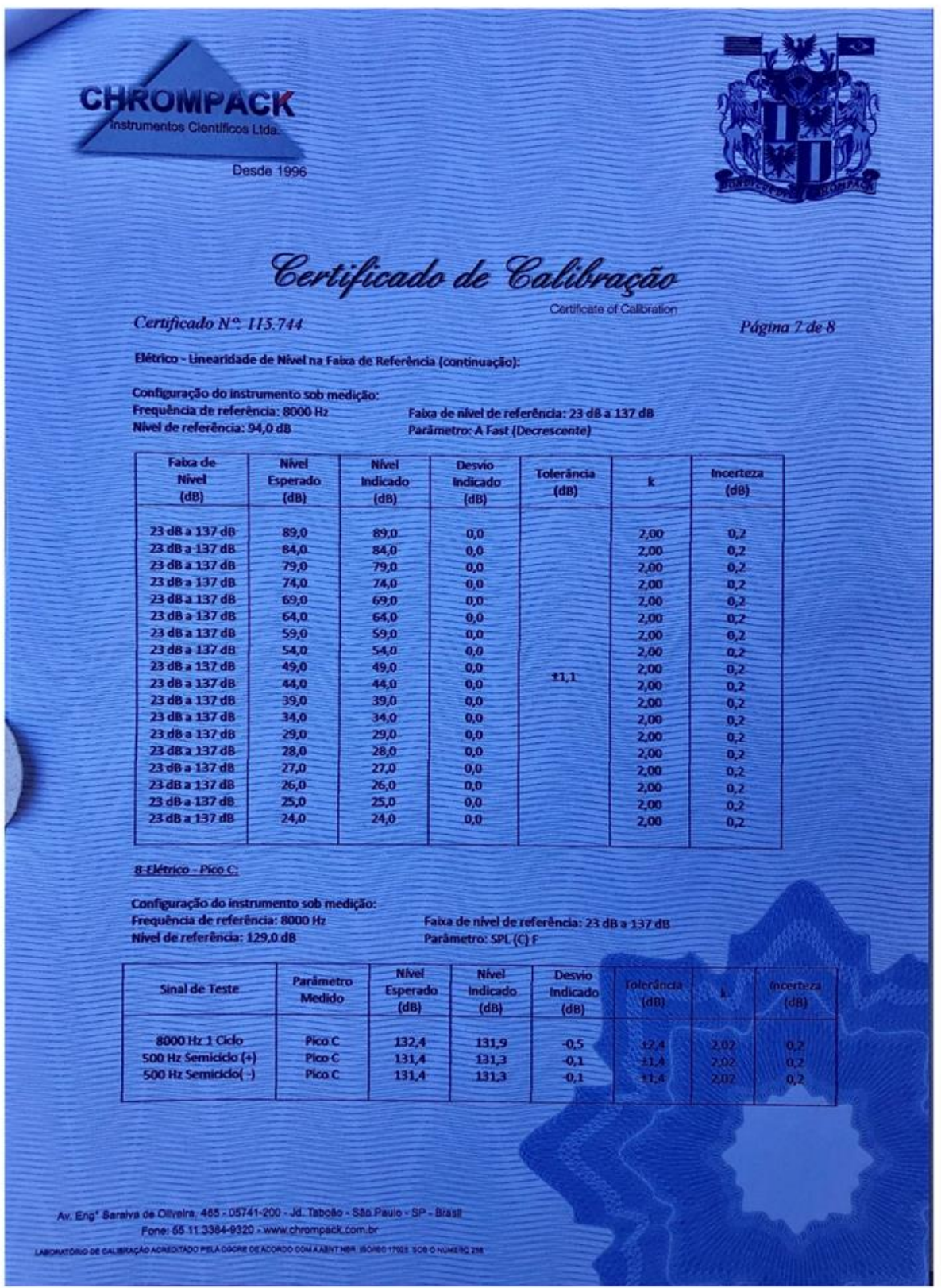




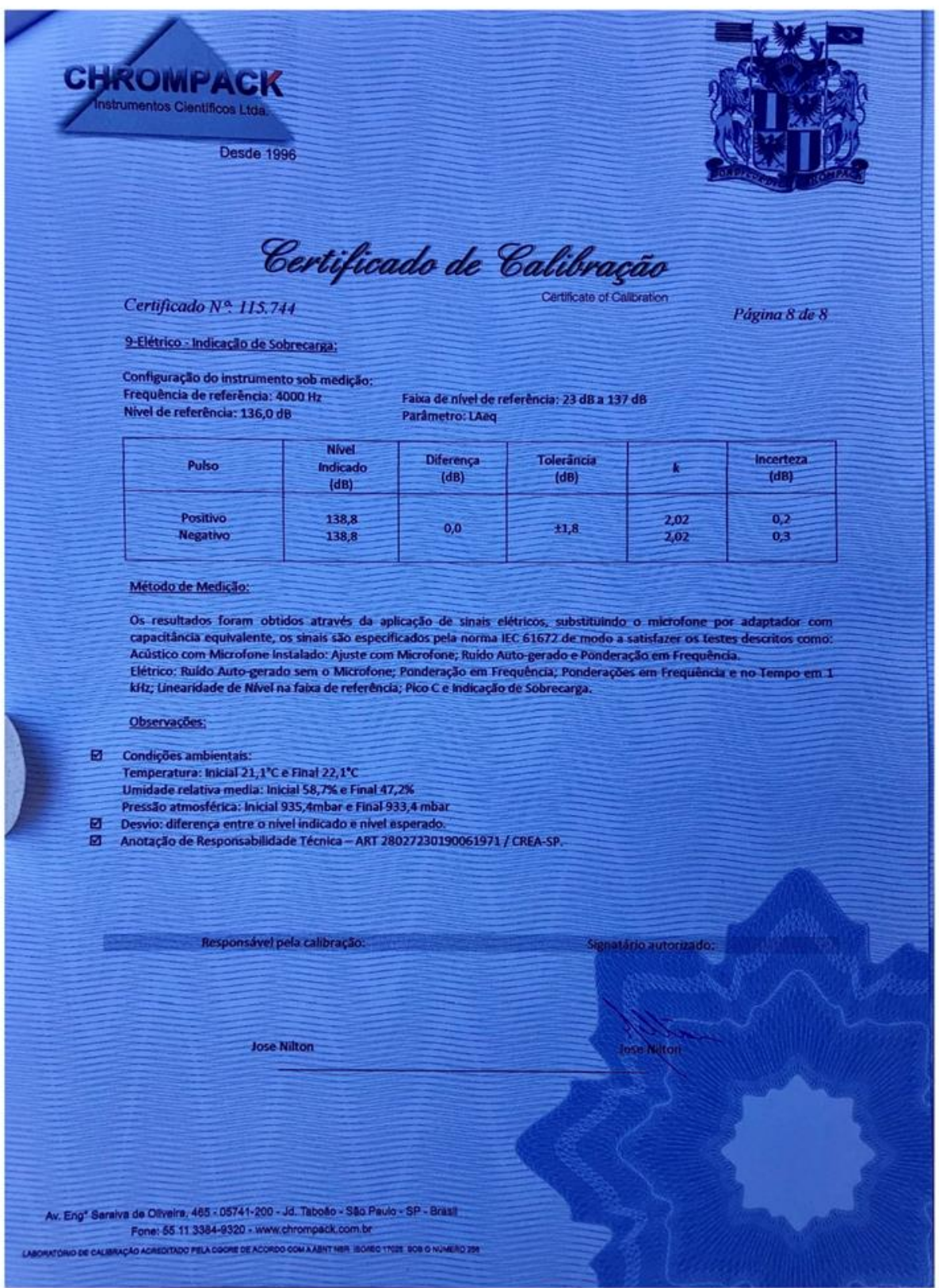




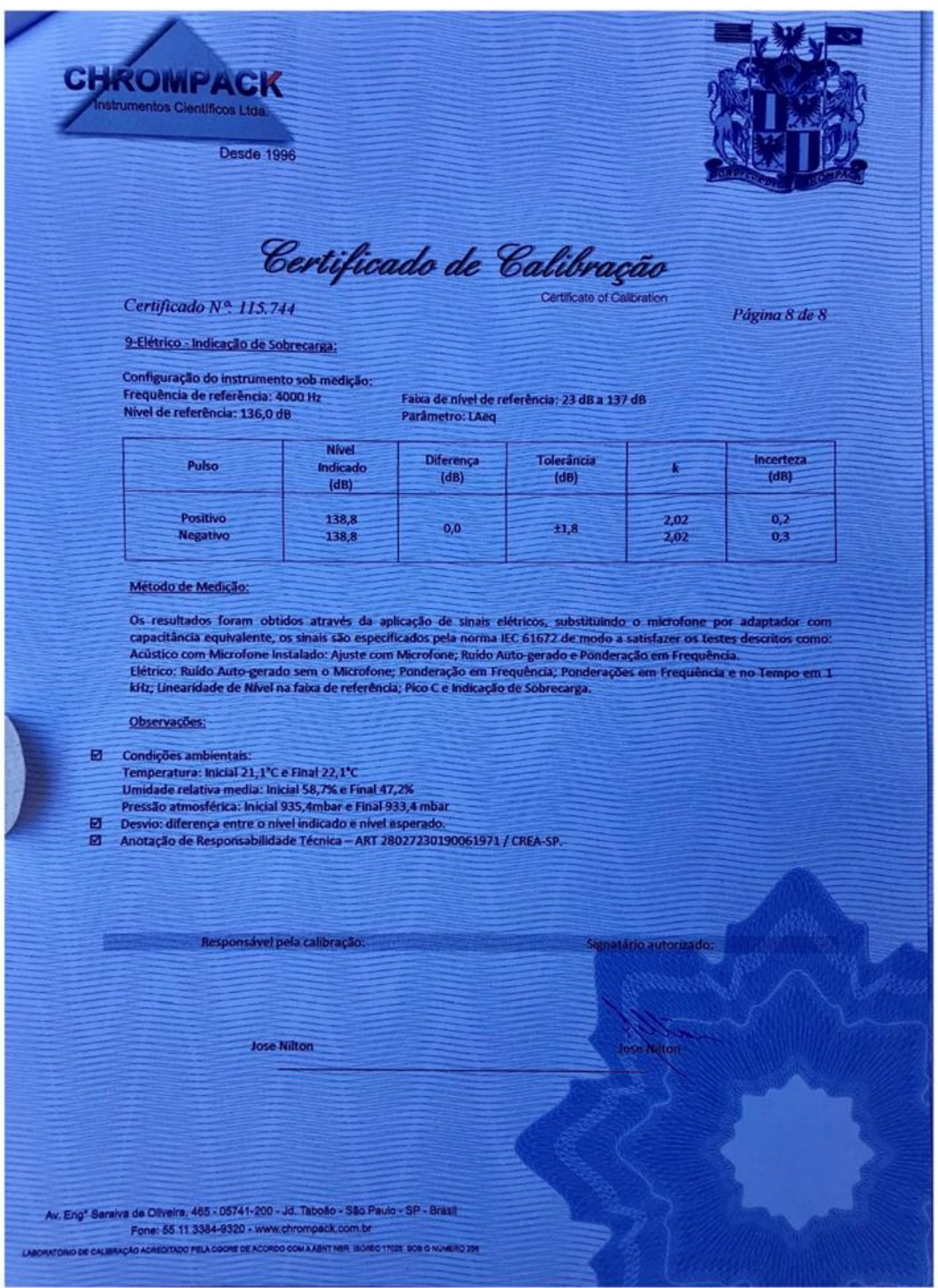

